\title{
Element Concentrations in Soils and Other Surficial Materials of the Conterminous United States
}

U.S. GEOLOGICAL SURVEY PROFESSIONAL PAPER 1270

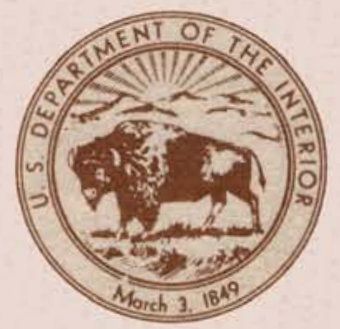




\section{Element Concentrations in Soils and Other Surficial Materials of the Conterminous United States}

By HANSFORD T. SHACKLETTE and JOSEPHINE G. BOERNGEN

U.S. GEOLOGICAL SURVEY PROFESSIONAL PAPER 1270

An account of the concentrations of

50 chemical elements in samples of

soils and other regoliths

UNITED STATES GOVERNMENT PRINTING OFFICE, WASHINGTON : 1984 
UNITED STATES DEPARTMENT OF THE INTERIOR

WILLIAM P. CLARK, Secretary

\author{
GEOLOGICAL SURVEY
}

Dallas L. Peck, Director

Library of Congress Cataloging in Publication Data

Shacklette, Hansford T.

Element concentrations in soils and other surficial materials of the conterminous United States.

(Geological Survey professional paper ; 1270)

Bibliography: $105 \mathrm{p}$.

Supt. of Docs. No.: I 19.16

1. Soils-United States-Composition.

I. Boerngen, Josephine G. II. Title. III. Series

S599.A1S5 $\quad 631.4^{\prime} 7^{\prime} 73 \quad 82-600084$

For sale by the Distribution Branch, U.S. Geological Survey, 604 South Pickett Street, Alexandria, VA 22304 


\section{CONTENTS}

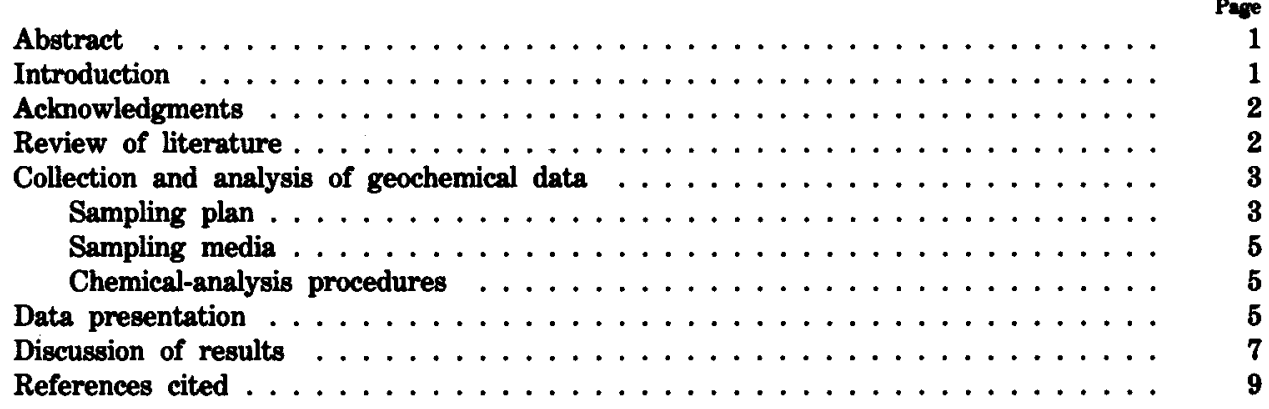

\section{ILLUSTRATIONS}

FIGURE 1. Map showing location of sampling sites in the conterminous United States where elements not commonly detected in surficial deposits were found, and the amounts of the elements present $\ldots \ldots \ldots \ldots \ldots$

2-47. Maps showing element content of surficial materials in the conterminous United States:

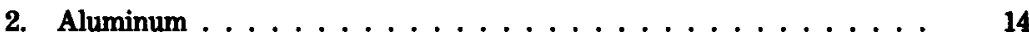

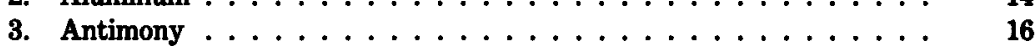

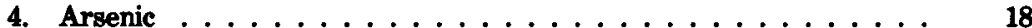

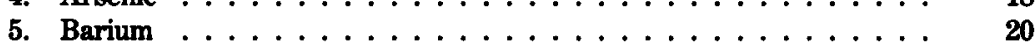

6. Beryllium ...................... 22

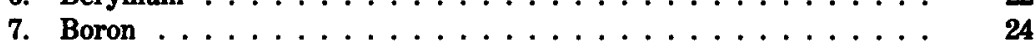

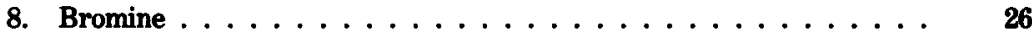

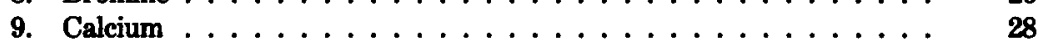

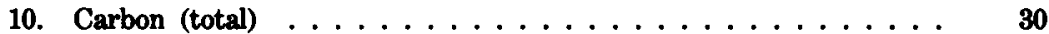

11. Cerium $\ldots \ldots \ldots \ldots \ldots \ldots \ldots \ldots \ldots \ldots \ldots$

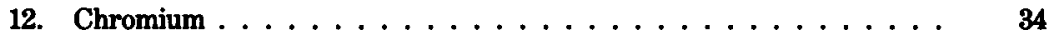

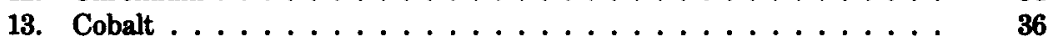

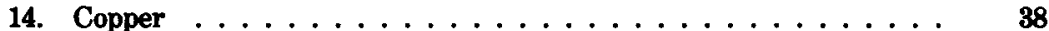

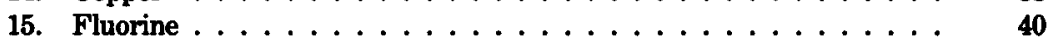

16. Gallium ......................... 42

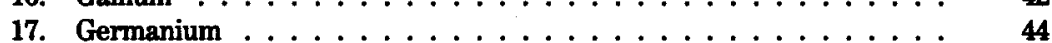

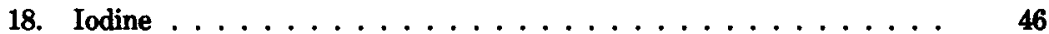

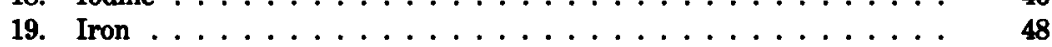

20. Lanthanum .............................. 50

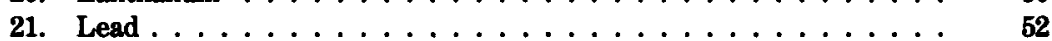

22. Lithium . . . . . . . . . . . . . . . . . 54

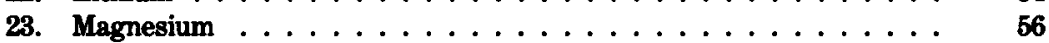

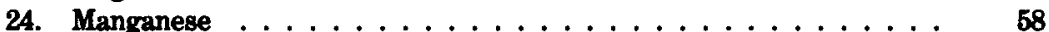

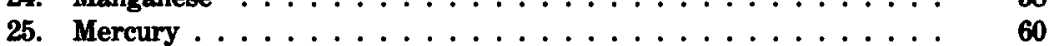

26. Molybdenum ..................... 62

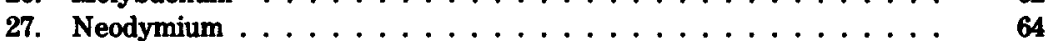

28. Nickel . . . . . . . . . . . . . . . . . . 66

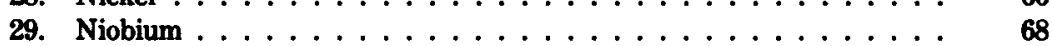

30. Phosphorus .................... 70

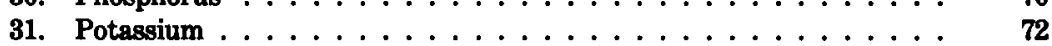

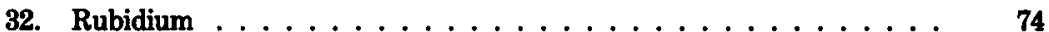

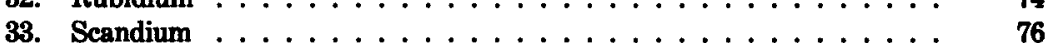

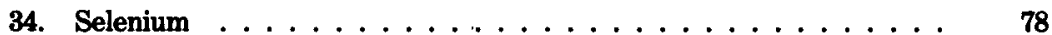

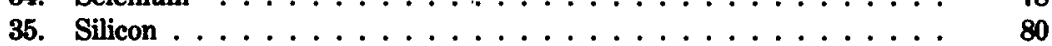

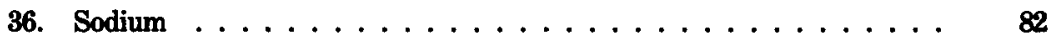


FIGURES 37-47. Maps showing element content of surficial materials in the conterminous United States:

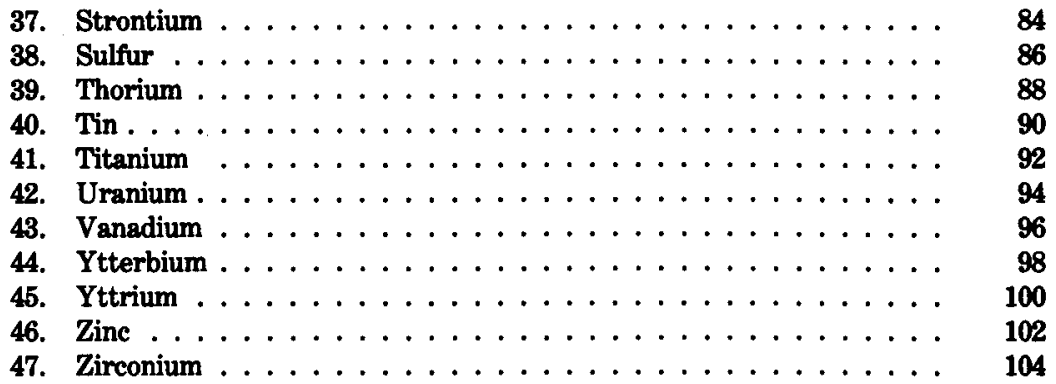

\section{TABLES}

TABLE 1. Average or median contents, and range in contents, reported for elements in soils and other surficial materials ..

2. Mean concentrations, deviations, and ranges of elements in samples of soils and other surficial materials in the conterminous

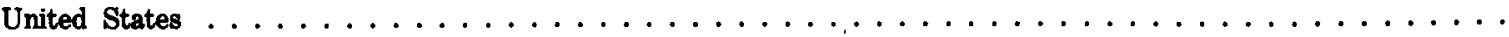




\title{
ELEMENT CONGENTRATIONS IN SOILS AND OTHER SURFICIAL MATERIALS OF THE CONTERMINOUS UNITED STATES
}

\author{
By Hansford T. Shacklette and Josephine G. Boerngen
}

\begin{abstract}
Samples of soils or other regoliths, taken at a depth of approximately $20 \mathrm{~cm}$ from locations about $80 \mathrm{~km}$ apart throughout the conterminous United States, were analyzed for their content of elements. In this manner, 1,318 sampling sites were chosen, and the results of the sample analyses for 50 elements were plotted on maps. The arithmetic and geometric mean, the geometric deviation, and a histogram showing frequencies of analytical values are given for 47 elements.

The lower concentrations of some elements (notably, aluminum, barium, calcium, magnesium, potassium, sodium, and strontium) in most samples of surficial materials from the Eastern United States, and the greater abundance of heavy metals in the same materials of the Western United States, indicates a regional geochemical pattern of the largest scale. The low concentrations of many elements in soils characterize the Atlantic Coastal Plain. Soils of the Pacific Northwest generally have high concentrations of aluminum, cobalt, iron, scandium, and vanadium, but are low in boron. Soils of the Rocky Mountain region tend to have high concentrations of copper, lead, and zinc. High mercury concentrations in surficial materials are characteristic of Gulf Coast sampling sites and the Atlantic coast sites of Connecticut, Massachuetts, and Maine. At the State level, Florida has the most striking geochemical pattern by having soils that are low in the concentrations of most elements considered in this study. Some smaller patterns of element abundance can be noted, but the degree of confidence in the validity of these patterns decreases as the patterns become less extensive.
\end{abstract}

\section{INTRODUCTION}

The abundance of certain elements in soils and other surficial materials is determined not only by the element content of the bedrock or other deposits from which the materials originated, but also by the effects of climatic and biological factors as well as by influences of agricultural and industrial operations that have acted on the materials for various periods of time. The diversity of these factors in a large area is expected to result in a corresponding diversity in the element contents of the surficial materials.

At the beginning of this study (1961), few data were available on the abundance of elements in surficial materials of the United States as a whole. Most of the early reports discussed only the elements that were of economic importance to mining or agriculture in a metallogenic area or State; and the data, for the most part, cannot be evaluated with reference to average, or normal, amounts in undisturbed materials because they were based on samples of deposits expected to have anomalous amounts of certain elements, or were based only on samples from cultivated fields.

We began a sampling program in 1961 that was designed to give estimates of the range of element abundance in surficial materials that were unaltered or very little altered from their natural condition, and in plants that grew on these deposits, throughout the conterminous United States. We believed that analyses of the surficial materials would provide a measure of the total concentrations of the elements that were present at the sampling sites, and that analysis of the plants would give an estimate of the relative concentrations among sites of the elements that existed in a chemical form that was available to plants. Because of the great amount of travel necessary to complete this sampling, we asked geologists and others of the U.S. Geological Survey to assist by collecting samples when traveling to and from their project areas and to contribute appropriate data they may have collected for other purposes. The reponse to this request, together with the samples and data that we had collected, resulted in our obtaining samples of surficial materials and plants from 863 sites. The analyses of surficial materials sampled in this phase of the study were published for 35 elements by plotting element concentrations, in two to five frequency classes, on maps (Shacklette, Hamilton, and others, 1971).

Soon after the publication of the results of this study, interest in environmental matters, particularly in the effects of contamination and industrial pollution, increased greatly. At the same time, technological advances in analytical methods and data processing facilitated measurements of geochemical and other parameters of the environment. In response to the need for background data for concentrations of certain elements of particular environmental concern, the samples of surficial materials that were collected for the first study (Shacklette, Hamilton, and others, 1971) (with some ad- 
ditional samples) were analyzed for other elements, and the results were published in U.S. Geological Survey Circulars: for mercury, Shacklette, Boerngen, and Turner (1971); for lithium and cadmium, by Shacklette, and others (1973); and for selenium, fluorine, and arsenic, Shacklette and others (1974).

The collection of samples for this study continued, as opportunities arose, until autumn 1975, resulting in the sampling of an additional 355 sites that were selected to give a more uniform geographical coverage of the conterminous United States. This sampling continuation is referred to as phase two. These samples were analyzed, and the data were merged with those of the original samples to produce the results given in the present report. In addition, the availability of analytical methods for elements not included in the earlier reports permitted data to be given on these elements in the more recently collected samples.

The collection localities and dates, sample descriptions, and analytical values for each sample in the present report were published by Boerngen and Shacklette (1981). The elemental compositions of only the surficial materials are given in this report; the data on analyses of the plant samples are held in files of the U.S. Geological Survey.

\section{ACKNOWLEDGMENTS}

This study was made possible by the cooperation of many persons in the U.S. Geological Survey. We thank D. F. Davidson, A. T. Miesch, J. J. Connor, R. J. Ebens, and A. T. Myers for their interest in, and continued support of, this study. The sampling plan was suggested by H. L. Cannon, who also contributed analytical data from her project areas and samples from her travel routes. Others of the Geological Survey who collected samples, and to whom we express gratitude, are: J. M. Bowles, F. A. Branson, R. A. Cadigan, F. C. Canney, F. W. Cater, Jr., M. A. Chaffey, Todd Church, J. J. Connor, Dwight Crowder, R. J. Ebens, I. A. Erdman, G. L. Feder, G. B. Gott, W. R. Griffitts, T. P. Hill, E. K. Jenne, M. I. Kaufman, J. R. Keith, Frank Kleinhampl, A. T. Miesch, R. F. Miller, R. C. Pearson, E. V. Post, Douglas Richman, R. C. Severson, James Scott, D. A. Seeland, M. H. Staatz, T. A. Steven, M. H. Strobell, V. E. Swanson, R. R. Tidball, H. A. Tourtelot, J. D. Vine, and R. W. White. We thank the following members of the U.S. Department of Agriculture Soil Conservation Service for providing soil samples from areas in Minnesota: D. D. Barron, C. R. Carlson, D. E. DeMartelaire, R. R. Lewis, Charles Sutton, and Paul Nyberg.

We acknowledge the analytical support provided by the following U.S. Geological Survey chemists: Lowell
Artis, Philip Aruscavage, A. J. Bartel, S. D. Bott L. A. Bradley, J. W. Budinsky, Alice Caemmerer, P. Cahill, E. Y. Campbell, G. W. Chloe, Don Col E. F. Cooley, N. M. Conklin, W. B. Crandell, Mauri Devalliere, P. L. D. Elmore, E. J. Finlay, Johnn Gardner, J. L. Glenn, T. F. Harms, R. G. Haven R. H. Heidel, M. B. Hinkle, Claude Huffman, Jr., ! B. Jenkins, R. J. Knight, B. W. Lanthorn, L. M. Let K. W. Leong, J. B. McHugh, J. D. Mensik, V. M. Me ritt, H. T. Millard, Jr., Wayne Mountjoy, H. I Nakagawa, H. G. Neiman, Uteana Oda, C. S. E. Papt R. L. Rahill, V. E. Shaw, G. D. Shipley, Hezekid Smith, A. J. Sutton, Jr., J. A. Thomas, Barbara Tobi J. E. Troxel, J. H. Turner, and G. H. VanSickle.

We were assisted in computer programming for th data by the following persons of the U.S. Geologici Survey: W. A. Buehrer, G. I. Evenden, J. B. Fife Allen Popiel, M. R. Roberts, W. C. Schomburg, G. I Selner, R. C. Terrazas, George VanTrump, Jr., and R. R. Wahl.

\section{REVIEW OF LITERATURE}

The literature on the chemical analysis of soils and other surficial materials in the United States is exter. sive and deals largely with specific agricultural prob lems of regional interest. Many of the papers were writ ten by soil scientists and chemists associated with State agricultural experiment stations and colleges of agricur ture, and most reports considered only elements that were known to be nutritive or toxic to plants or ani mals.

Chemists with the U.S. Department of Agriculture prepared most early reports of element abundance in soils for large areas of the United States. (See Robinson, 1914; Robinson and others, 1917). The 1938 yearbook of agriculture was devoted to reports on soils of the United States; in this book, McMurtrey and Robinson (1938) discussed the importance and abundance of trace elements in soils. Amounts of the major elements in soil samples from a few soil profiles distributed throughout the United States were compiled by the soil scientist C. F. Marbut (1935) to illustrate characteristies of soil units.

The use of soil analysis in geochemical prospecting began in this country in the 1940's, and many reports were published on the element amounts in soils from areas where mineral deposits were known or suspected to occur. Most of these reports included only a few elements in soils from small areas. This early geochemical work was discussed by Webb (1953) and by Hawkes (1957). In succeeding years, as soil analyses became an accepted method of prospecting and as analytical 
methods were improved, many elements in soils were analyzed; still, the areas studied were commonly small.

An estimate of the amounts of elements in average, or normal, soils is useful in appraising the amounts of elements in a soil sample as related to agricultural, mineral prospecting, environmental quality, and health and disease investigations. Swaine (1955) gave an extensive bibliography of trace-element reports on soils of the world, and he also summarized reports of the average amounts of elements as given by several investigators. The most comprehensive list of average amounts of rare and dispersed elements in soils is that of Vinogradov (1959), who reported the analytical results of extensive studies of soils in the Union of Soviet Socialist Republics, as well as analyses of soils from other countries. He did not state the basis upon which he established the average values; however, these values are presumably the arithmetic means of element amounts in samples from throughout the world. In their discussions of the principles of geochemistry, Goldschmidt (1954) and Rankama and Sahama (1955) reported the amounts of various elements present in soils and in other surficial materials, Hawks and Webb (1962) and, more recently, Brooks (1972), Siegal (1974), Levinson (1974), and Rose and others (1979) gave average amounts of certain elements in soils as useful guides in mineral exploration.

A report on the chemical characteristics of soils was edited by Bear (1964). In this book, the chapter on chemical composition of soils by Jackson (1964) and the chapter on trace elements in soils by Mitchell (1964) gave the ranges in values or the average amounts of some soil elements.

Regional geochemical studies conducted by scientists of the U.S. Geological Survey within the past two decades have been largely directed to the establishment of baseline abundances of elements in surficial materials, including soils. Most of the earlier work investigated these materials that occurred in their natural condition, having little or no alterations that related to human activities, with the objective of establishing normal element concentrations in the materials by which anomalous concentrations, both natural or man induced, could be judged. Some of these studies were conducted in cooperation with medical investigators who were searching for possible relationships of epidemiological patterns to characteristics of the environment. In one study, the geochemical characteristics of both natural and cultivated soils were determined in two areas of Georgia that had contrasting rates of cardiovascular diseases (Shacklette and others, 1970). In an extensive geochemical study of Missouri, also conducted cooperatively with medical researchers, both cultivated and natural soils were sampled. The results were presented for the State as a whole, and for physiographic regions or other subdivisions and smaller areas, as follows: Erdman and others (1976a, 1976b); Tidball (1976, 1983a, $1983 \mathrm{~b})$; and Ebens and others (1973). The results of these studies, and of other regional geochemical investigations, were summarized and tabulated by Connor and Shacklette (1975).

Recent regional studies of soil geochemistry by the U.S. Geological Survey related to the development of energy resources in the western part of the United States, including North Dakota, South Dakota, Montana, Wyoming, Colorado, Utah, and New Mexico. These studies established regional geochemical baselines for soils, both in undisturbed areas and in areas that had been altered by mining and related activities. Some of these studies considered the elements in soils both as total concentrations and as concentrations that were available to plants of the region. The results of these studies were published in annual progress reports (U.S. Geological Survey, 1974, 1975, 1976, 1977, and 1978). The data on soils, as well as on other natural materials, in these reports were summarized and tabulated by Ebens and Shacklette (1981). In a study of the elements in fruits and vegetables from 11 areas of commercial production in the United States, and in the soils on which this produce grew, soils were analyzed for 39 elements, as reported by Boerngen and Shacklette (1980) and Shacklette (1980).

The average amounts of elements in soils and other surficial materials of the United States, as determined in the present study, are given in table 1 , with the average values or ranges in values that were reported by Vinogradov (1959), Rose and others (1979), Jackson (1964), Mitchell (1964), and Brooks (1972). The averages from the present study given in table 1 are the arithmetic means. Although the averages were computed by the methods described by Miesch (1967), the values obtained are directly comparable with the arithmetic means derived by common computational procedures.

\section{COLLECTION AND ANALYSIS OF GEOCHEMICAL DATA}

\section{SAMPLING PLAN}

The sampling plan was designed with the emphasis on practicality, in keeping with the expenditures of time and funds available, and its variance from an ideal plan has been recognized from the beginning. Because the collection of most samples was, by necessity, incidental to other duties of the samplers, the instructions for sampling were simplified as much as possible, so that sampling methods would be consistent within the wide range of kinds of sites to be sampled: The samples were 
TABLE 1.-Average or median contents, and range in contents, reported for elements in soils and other surficial materials [Data are in parts per million; each average represents arithmetic mean; leaders $(\rightarrow$ in figure columns indicate no data available. A, average; $\mathbf{M}$, median. <, less than;
\[ \text {, greater than] } \]

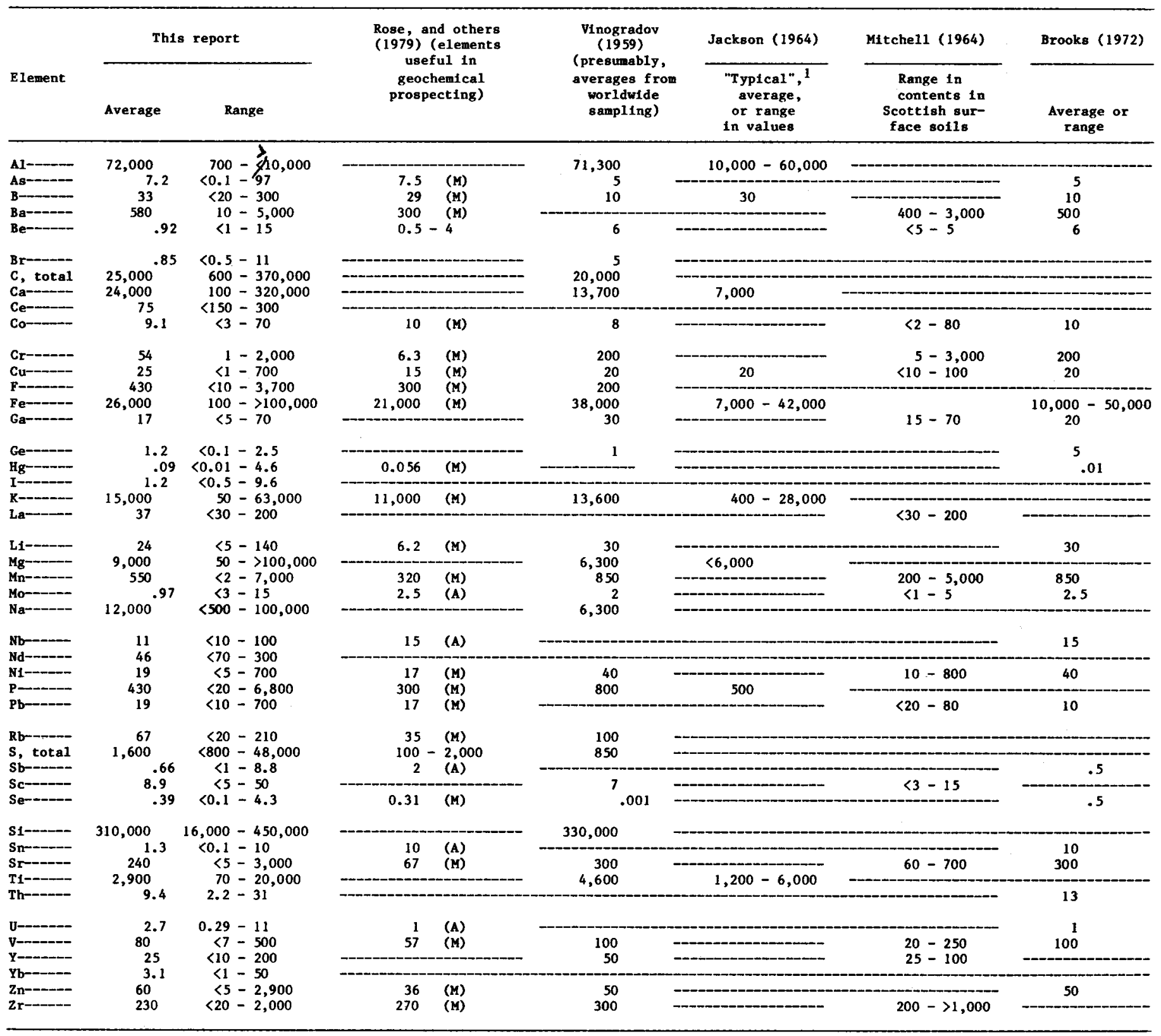

1Author's usage; generally used to indicate the most commonly occurring value.

collected by U.S. Geological Survey personnel along their routes of travel to areas of other types of field studies or within their project areas.

The locations of the routes that were sampled depended on both the network of roads that existed and the destinations of the samplers. Sampling intensity was kept at a minimum by selecting only one sampling site every $80 \mathrm{~km}$ (about 50 miles; selected for convenience because vehicle odometers were calibrated in miles) along the routes. The specific sampling sites were selected, insofar as possible, that had surficial materials that were very little altered from their natural condition and that supported native plants suitable for sampling. In practice, this site selection necessitated sampling away from roadcuts and fills. In some areas, only cultivated fields and plants were available for sampling.

Contamination of the sampling sites by vehicular emissions was seemingly insignificant, even though many sites were within $100 \mathrm{~m}$ or less of the roads. Col- 
lecting samples at about $20 \mathrm{~cm}$ depth, rather than at the upper soil horizons, may have avoided the effects of surface contamination on the samples. However, we had no adequate way of measuring any contamination that may have occurred. (See Cannon and Bowles, 1962.) Many of the sampled routes had only light vehicular traffic, and some were new interstate highways. Routes through congested areas generally were not sampled; therefore, no gross contamination of the samples was expected.

The study areas that were sampled follow: Wisconsin and parts of contiguous States, southeastern Missouri, Georgia, and Kentucky, sampled by Shacklette; Kentucky, sampled by J. J. Connor and R. R. Tidball; Nevada, New Mexico, and Maryland, sampled by $\mathrm{H}$. L. Cannon; various locations in Arizona, Colorado, Montana, New Mexico, Utah, and Wyoming, sampled by F. A. Branson and R. F. Miller; Missouri, sampled by Shacklette, J. A. Erdman, J. R. Keith, and R. R. Tidball; and various locations in Colorado, Idaho, Montana, South Dakota, Utah, and Wyoming, sampled by A. T. Miesch and J. J. Connor. Sampling techniques used in these areas varied according to the primary objectives of the studies being conducted, but generally these techniques were closely similar to the methods used in sampling along the roads.

In general, the sampling within study areas was more intensive than that along the travel routes. To make the sampling intensity of the two sampling programs more nearly equal, only the samples from selected sites in the study areas were used for this report. The selected sites were approximately $80 \mathrm{~km}$ apart. Where two or more samples were collected from one site, they were assigned numbers, and one of these samples was randomly chosen for evaluation in this study.

\section{SAMPLING MEDIA}

The material sampled at most sites could be termed "soil" because it was a mixture of comminuted rock and organic matter, it supported ordinary land plants, and it doubtless contained a rich microbiota. Some of the sampled deposits, however, were not soils as defined above, but were other kinds of regoliths. The regoliths included desert sands, sand dunes, some loess deposits, and beach and alluvial deposits that contained little or no visible organic matter. In some places the distinctions between soils and other regoliths are vague because the materials of the deposits are transitional between the two. Samples were collected from a few deposits consisting mostly of organic materials that would ordinarily be classified as peat, rather than soil.

To unify sampling techniques, the samplers were asked to collect the samples at a depth of approximately $20 \mathrm{~cm}$ below the surface of the deposits. This depth was chosen as our estimate of a depth below the plow zone that would include parts of the zone of illuviation in most well-developed zonal soils, and as a convenient depth for sampling other surficial materials. Where the thickness of the material was less than $20 \mathrm{~cm}$, as in shallow soils over bedrock or in lithosols over large rock fragments, samples were taken of the material that lay iust above the rock deposits. About 0.25 liter of this material was collected, put in a kraft paper envelope, and shipped to the U.S. Geological Survey laboratories in Denver, Colo.

\section{CHEMICAL-ANALYSIS PROCEDURES}

The soil samples were oven dried in the laboratory and then sifted through a 2-mm sieve. If the soil material would not pass this sieve, the sample was pulverized in a ceramic mill before seiving. Finally, the sifted, minus 2-mm fraction of the sample was used for analysis.

The methods of analysis used for some elements were changed during the course of this study, as new techniques and instruments became available. For most elements, the results published in the first report (Shacklette, Hamilton, and others, 1971) were obtained by use of a semiquantitative six-step emission spectrographic method (Meyers and others, 1961). The methods used for other elements were: EDTA titration for calcium; colorimetric (Ward and others, 1963) for phosphorus and zinc; and flame photometry for potassium. Many of the elements analyzed in the 355 samples collected in phase two of the study were also analyzed by the emission spectrographic method (Neiman, 1976). Other methods were used for the following elements: flame atomic absorption (Huffman and Dinnin, 1976) for mercury, lithium, magnesium, sodium, rubidium, and zinc; flameless atomic absorption (Vaughn, 1967) for mercury; X-ray fluorescence spectrometry (Wahlberg, 1976) for calcium, germanium, iron, potassium, selenium, silver, sulfur, and titanium; combustion (Huffman and Dinnin, 1976) for total carbon; and neutron activation (Millard, 1975, 1976) for thorium and uranium.

\section{DATA PRESENTATION}

Summary data for 46 elements are reported in tables 1 and 2. In table 1, the element concentrations found in samples of soil and other surficial materials of this study are compared with those in soils reported in other studies. Arithmetic means are used for the data of this study to make them more readily compared with the data generally reported in the literature. These arithmetic means were derived from the estimated geometric means by using a technique described by Miesch (1967), which is based on methods devised by Cohen (1959) and Sichel (1952). The arithmetic means in table 
1 , unlike the geometric means shown in table 2, are estimates of geochemical abundance (Miesch, 1967). Arithmetic means are always larger than corresponding geometric means (Miesch, 1967, p. B1) and are estimates of the fractional part of a single specimen that consists of the element of concern rather than of the typical concentration of the element in a suite of samples.
Concentrations of 46 elements in samples of this study are presented in table 2 , which gives the determination ratios, geometric-mean concentrations and deviations, and observed ranges in concentrations. The analytical data for most elements as received from the laboratories were transformed into logarithms because of the tendency for elements in natural materials, particularly the trace elements, to have positively skewed

TABLE 2,-Mean concentrations, deviations, and ranges of elements in samples of soils and other surficial materials in the conterminous United States

[Means and ranges are reported in parts per million $(\mu \mathrm{g} / \mathrm{g})$, and means and deviations are geometric except as indicated. Ratio, number of samples in which the element was found in measurable concentrations to number of samples analyzed. <, less than; >, greater than]

\begin{tabular}{|c|c|c|c|c|c|c|c|c|c|c|c|c|c|}
\hline \multirow{2}{*}{ Element } & \multicolumn{3}{|c|}{$\begin{array}{l}\text { Conterminous } \\
\text { United States }\end{array}$} & \multicolumn{5}{|c|}{$\begin{array}{l}\text { Western United States } \\
\text { (west of } 96 \text { th meridian) }\end{array}$} & \multicolumn{4}{|c|}{$\begin{array}{l}\text { Eastern United States } \\
\text { (east of } 96 \mathrm{th} \text { meridian) }\end{array}$} & \multirow[b]{2}{*}{$\begin{array}{c}\text { Estimated } \\
\text { arithmetic } \\
\text { mean }\end{array}$} \\
\hline & Mean & $\begin{array}{l}\text { Devia- } \\
\text { tion }\end{array}$ & $\begin{array}{l}\text { Estimated } \\
\text { arithmetic } \\
\text { mean }\end{array}$ & Ratio & Mean & $\begin{array}{l}\text { Devia- } \\
\text { tion }\end{array}$ & $\begin{array}{l}\text { Observed } \\
\text { range }\end{array}$ & $\begin{array}{l}\text { Estimated } \\
\text { arithmetic } \\
\text { mean }\end{array}$ & Ratio & Mean & $\begin{array}{l}\text { Devia- } \\
\text { tion }\end{array}$ & $\begin{array}{l}\text { Observed } \\
\text { range }\end{array}$ & \\
\hline $\begin{array}{l}\mathrm{Al} \text {, percent } \\
\mathrm{As}-\mathrm{Ba}-\mathrm{-} \\
\mathrm{Be}-\end{array}$ & $\begin{array}{r}4.7 \\
5.2 \\
26 \\
440 \\
.63\end{array}$ & $\begin{array}{l}2.48 \\
2.23 \\
1.97 \\
2.14 \\
2.38\end{array}$ & $\begin{array}{c}7.2 \\
7.2 \\
33 \\
580 \\
.92\end{array}$ & $\begin{array}{l}661: 770 \\
728: 730 \\
506: 778 \\
778: 778 \\
310: 778\end{array}$ & $\begin{array}{c}5.8 \\
5.5 \\
23 \\
580 \\
.68\end{array}$ & $\begin{array}{l}2.00 \\
1.98 \\
1.99 \\
1.72 \\
2.30\end{array}$ & $\begin{array}{c}0.5->10 \\
<0.10-97 \\
<20-300 \\
70=5,000 \\
<1=15\end{array}$ & $\begin{array}{r}7.4 \\
7.0 \\
29 \\
670 \\
.97\end{array}$ & $\begin{array}{l}450: 477 \\
521: 527 \\
425: 541 \\
541: 541 \\
169: 525\end{array}$ & $\begin{array}{c}3.3 \\
4.8 \\
31 \\
290 \\
.55\end{array}$ & $\begin{array}{l}2.87 \\
2.56 \\
1.88 \\
2.35 \\
2.53\end{array}$ & $\begin{array}{l}0.7->10 \\
<0.1-73 \\
<20-150 \\
10-1,500 \\
<1-7\end{array}$ & $\begin{array}{l}5.7 \\
7.4 \\
38 \\
420 \\
.85\end{array}$ \\
\hline $\begin{array}{l}\mathrm{Br}- \\
\mathrm{C} \text {, percent- } \\
\mathrm{Ca} \text {, percent } \\
\mathrm{Ce}-\end{array}$ & $\begin{array}{c}.56 \\
1.6 \\
.92 \\
63 \\
6.7\end{array}$ & $\begin{array}{l}2.50 \\
2.57 \\
4.00 \\
1.78 \\
2.19\end{array}$ & $\begin{array}{l}.85 \\
2.5 \\
2.4 \\
75 \\
9.1\end{array}$ & $\begin{array}{r}113: 220 \\
250: 250 \\
777: 777 \\
81: 683 \\
698: 778\end{array}$ & $\begin{array}{l}.52 \\
1.7 \\
1.8 \\
65 \\
7.1\end{array}$ & $\begin{array}{l}2.74 \\
2.37 \\
3.05 \\
1.71 \\
1.97\end{array}$ & $\begin{array}{l}<0.5-11 \\
0.16-10 \\
0.06-32 \\
<150-300 \\
<3-50\end{array}$ & $\begin{array}{l}.86 \\
2.5 \\
3.3 \\
75 \\
9.0\end{array}$ & $\begin{array}{r}78: 128 \\
162: 162 \\
514: 514 \\
70: 489 \\
403: 533\end{array}$ & $\begin{array}{c}.62 \\
1.5 \\
.34 \\
63^{.34} \\
5.9\end{array}$ & $\begin{array}{l}2.18 \\
2.88 \\
3.08 \\
1.85 \\
2.57\end{array}$ & $\begin{array}{l}<0.5-5.3 \\
0.06-37 \\
0.01-28 \\
<150-300 \\
<0.3-70\end{array}$ & $\begin{array}{l}.85 \\
2.6 \\
.63 \\
76^{.63}\end{array}$ \\
\hline $\begin{array}{l}\text { Cr- } \\
\text { Cu- } \\
\text { Fe, percent } \\
\text { Ga-pen }\end{array}$ & $\begin{array}{c}37 \\
17 \\
210 \\
1.8 \\
13\end{array}$ & $\begin{array}{l}2.37 \\
2.44 \\
3.34 \\
2.38 \\
2.03\end{array}$ & $\begin{array}{l}54 \\
25 \\
430 \\
2.6 \\
17\end{array}$ & $\begin{array}{l}778: 778 \\
778: 778 \\
598: 610 \\
776: 777 \\
767: 776\end{array}$ & $\begin{array}{c}41 \\
21 \\
280 \\
2.1 \\
16\end{array}$ & $\begin{array}{l}2.19 \\
2.07 \\
2.52 \\
1.95 \\
1.68\end{array}$ & $\begin{aligned} 3 & -2,000 \\
2 & =300 \\
<10 & =1,900 \\
0.1 & =>10 \\
<5 & =70\end{aligned}$ & $\begin{array}{c}56 \\
27 \\
440 \\
2.6 \\
19\end{array}$ & $\begin{array}{l}541: 541 \\
523: 533 \\
390: 435 \\
539: 540 \\
431: 540\end{array}$ & $\begin{array}{c}33 \\
13 \\
130 \\
1.4 \\
9.3\end{array}$ & $\begin{array}{l}2.60 \\
2.80 \\
4.19 \\
2.87 \\
2.38\end{array}$ & $\begin{aligned} 1-1,000 \\
<1-700 \\
<10-3,700 \\
0.01->10 \\
<5-70\end{aligned}$ & $\begin{array}{c}52 \\
22 \\
360 \\
2.5 \\
14\end{array}$ \\
\hline 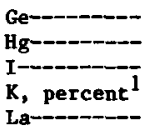 & $\begin{array}{l}1.2 \\
.058 \\
.75 \\
1.5 \\
30\end{array}$ & $\begin{array}{r}1.37 \\
2.52 \\
2.63 \\
.79 \\
1.92\end{array}$ & $\begin{array}{c}1.2 \\
.089 \\
1.2 \\
\text { None } \\
37\end{array}$ & $\begin{array}{l}224: 224 \\
729: 733 \\
169: 246 \\
777: 777 \\
462: 777\end{array}$ & $\begin{array}{l}1.2 \\
.046 \\
.79 \\
1.8 \\
30\end{array}$ & $\begin{array}{l}1.32 \\
2.33 \\
2.55 \\
.71 \\
1.89\end{array}$ & $\begin{array}{r}0.58-2.5 \\
<0.01-4.6 \\
<0.5-9.6 \\
0.19-6.3 \\
<30-200\end{array}$ & $\begin{array}{l}1.2 \\
.065 \\
1.2 \\
\text { None } \\
37\end{array}$ & $\begin{array}{r}130: 131 \\
534: 534 \\
90: 153 \\
537: 537 \\
294: 516\end{array}$ & $\begin{array}{l}1.1 \\
.081 \\
.68 \\
1.2 \\
29\end{array}$ & $\begin{array}{l}1.45 \\
2.52 \\
2.81 \\
1.75 \\
1.98\end{array}$ & $\begin{array}{r}<0.1-2.0 \\
0.01-3.4 \\
<0.5-7.0 \\
0.005-3.7 \\
<30-200\end{array}$ & $\begin{array}{l}1.2 \\
.12 \\
1.2 \\
--\end{array}$ \\
\hline $\begin{array}{l}\text { L1-- } \\
\text { Mg, percent } \\
\text { Mo-- } \\
\mathrm{Na,} \text {, percent }\end{array}$ & $\begin{array}{l}330^{20} .44 \\
.59 \\
.59\end{array}$ & $\begin{array}{l}1.85 \\
3.28 \\
2.77 \\
2.72 \\
3.27\end{array}$ & $\begin{array}{l}550 \\
.90 \\
1.2\end{array}$ & $\begin{array}{r}731: 731 \\
777: 778 \\
777: 777 \\
57: 774 \\
744: 744\end{array}$ & $\begin{array}{r}22 \\
380^{.74} \\
.85 \\
.97\end{array}$ & $\begin{array}{l}1.58 \\
2.21 \\
1.98 \\
2.17 \\
1.95\end{array}$ & $\begin{array}{c}5-130 \\
0.03->10 \\
30-5,000 \\
<3-7 \\
0.05-10\end{array}$ & $\begin{array}{l}25 \\
1.0 \\
480 \\
1.1 \\
1.2\end{array}$ & $\begin{array}{r}479: 527 \\
528: 528 \\
537: 540 \\
32: 524 \\
363: 449\end{array}$ & $\begin{array}{l}17 \\
260^{.21} \\
.32 \\
.25\end{array}$ & $\begin{array}{l}2.16 \\
3.55 \\
3.82 \\
3.93 \\
4.55\end{array}$ & $\begin{array}{c}<5-140 \\
0.005=5 \\
<2=7,000 \\
<3=15 \\
<0.05-5\end{array}$ & $\begin{array}{r}22 \\
640^{.46} \\
.79 \\
.78\end{array}$ \\
\hline 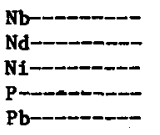 & $\begin{array}{l}9.3 \\
40 \\
13 \\
260 \\
16\end{array}$ & $\begin{array}{l}1.75 \\
1.68 \\
2.31 \\
2.67 \\
1.86\end{array}$ & $\begin{array}{c}11 \\
46 \\
19 \\
430 \\
19\end{array}$ & $\begin{array}{l}418: 771 \\
120: 538 \\
747: 778 \\
524: 524 \\
712: 778\end{array}$ & $\begin{array}{l}8.7 \\
36 \\
15 \\
120 \\
17\end{array}$ & $\begin{array}{l}1.82 \\
1.76 \\
2.10 \\
2.33 \\
1.80\end{array}$ & $\begin{array}{l}<10-100 \\
<70-300 \\
<5-700 \\
40-4,500 \\
<10-700\end{array}$ & $\begin{array}{r}10 \\
43 \\
19 \\
460 \\
20\end{array}$ & $\begin{array}{l}322: 498 \\
109: 332 \\
443: 540 \\
380: 382 \\
422: 541\end{array}$ & $\begin{array}{r}10 \\
46 \\
11 \\
200 \\
14\end{array}$ & $\begin{array}{l}1.65 \\
1.58 \\
2.64 \\
2.95 \\
1.95\end{array}$ & $\begin{array}{l}<10-50 \\
<70=300 \\
<5=700 \\
<20=6,800 \\
<10-300\end{array}$ & $\begin{array}{r}12 \\
51 \\
18 \\
360 \\
17\end{array}$ \\
\hline $\begin{array}{l}\text { Rb----- } \\
\mathrm{S} \text {, percent- } \\
\mathrm{Sb}- \\
\mathrm{Sc}- \\
\mathrm{Se}-\end{array}$ & $\begin{array}{l}58 \\
.12 \\
.48 \\
7.5 \\
.26\end{array}$ & $\begin{array}{l}1.72 \\
2.04 \\
2.27 \\
1.82 \\
2.46\end{array}$ & $\begin{array}{l}67 \\
.16 \\
.67 \\
8.9 \\
.39\end{array}$ & $\begin{array}{r}221: 224 \\
34: 224 \\
35: 223 \\
685: 778 \\
590: 733\end{array}$ & $\begin{array}{c}69 \\
.13 \\
.47 \\
8.2 \\
.23\end{array}$ & $\begin{array}{l}1.50 \\
2.37 \\
2.15 \\
1.74 \\
2.43\end{array}$ & $\begin{aligned}<20-210 \\
<0.08-4.8 \\
<1-2.6 \\
<5-50 \\
<0.1-4.3\end{aligned}$ & $\begin{array}{c}74 \\
.19 \\
.62 \\
9.6 \\
.34\end{array}$ & $\begin{array}{r}107: 131 \\
20: 131 \\
31: 131 \\
389: 526 \\
449: 534\end{array}$ & $\begin{array}{l}43 \\
.10 \\
.52 \\
6.5 \\
.30\end{array}$ & $\begin{array}{l}1.94 \\
1.34 \\
2.38 \\
1.90 \\
2.44\end{array}$ & $\begin{array}{c}<20-160 \\
<0.08-0.31 \\
<1-8.8 \\
<5-30 \\
<0.1-3.9\end{array}$ & $\begin{array}{l}53 \\
.11 \\
.76 \\
8.0 \\
.45\end{array}$ \\
\hline $\begin{array}{l}\text { Si, percent } \\
\text { Sn- } \\
\text { Sr-- } \\
\text { Ti, percent } \\
\text { Th- }\end{array}$ & $\begin{array}{c}120^{31} .89 \\
.24 \\
8.6\end{array}$ & $\begin{array}{l}6.48 \\
2.36 \\
3.30 \\
1.89 \\
1.53\end{array}$ & $\begin{array}{c}\text { None } \\
1.3 \\
240 \\
.29 \\
9.4\end{array}$ & $\begin{array}{l}250: 250 \\
218: 224 \\
778: 778 \\
777: 777 \\
195: 195\end{array}$ & $\begin{array}{c}30 \\
200 \\
9.90 \\
9.1\end{array}$ & $\begin{array}{l}5.70 \\
2.11 \\
2.16 \\
1.78 \\
1.49\end{array}$ & $\begin{array}{c}15-44 \\
<0.1-7.4 \\
10-3,000 \\
0.05=2.0 \\
2.4-31\end{array}$ & $\begin{array}{l}\text { None } \\
1.2 \\
270 \\
.26 \\
9.8\end{array}$ & $\begin{array}{l}156: 156 \\
123: 131 \\
501: 540 \\
540: 540 \\
102: 102\end{array}$ & $\begin{array}{c}5^{34} .86 \\
7.28\end{array}$ & $\begin{array}{l}6.64 \\
2.81 \\
3.61 \\
2.00 \\
1.58\end{array}$ & $\begin{aligned} 1.7 & -45 \\
<0.1 & -10 \\
<5 & -700 \\
0.007 & -1.5 \\
2.2 & -23\end{aligned}$ & $\begin{array}{c}-- \\
1.5 \\
120 \\
.35 \\
8.6\end{array}$ \\
\hline 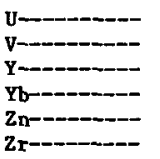 & $\begin{array}{l}2.3 \\
58 \\
21 \\
2.6 \\
48 \\
180\end{array}$ & $\begin{array}{l}1.73 \\
2.25 \\
1.78 \\
1.79 \\
1.95 \\
1.91\end{array}$ & $\begin{array}{l}2.7 \\
80 \\
25 \\
3.1 \\
60 \\
230\end{array}$ & $\begin{array}{l}224: 224 \\
778: 778 \\
759: 778 \\
754: 764 \\
766: 766 \\
777: 778\end{array}$ & $\begin{array}{c}2.5 \\
70 \\
22 \\
2.6 \\
55 \\
160\end{array}$ & $\begin{array}{l}1.45 \\
1.95 \\
1.66 \\
1.63 \\
1.79 \\
1.77\end{array}$ & $\begin{aligned} & 0.68-7.9 \\
& 7-500 \\
&<10-150 \\
&<1-20 \\
& 10-2,100 \\
&<20-1,500\end{aligned}$ & $\begin{array}{l}2.7 \\
88 \\
25 \\
3.0 \\
65 \\
190\end{array}$ & $\begin{array}{l}130: 130 \\
516: 541 \\
477: 541 \\
452: 486 \\
473: 482 \\
539: 541\end{array}$ & $\begin{array}{c}2.1 \\
43 \\
20 \\
2.6 \\
40 \\
220\end{array}$ & $\begin{array}{l}2.12 \\
2.51 \\
1.97 \\
2.06 \\
2.11 \\
2.01\end{array}$ & $\begin{aligned} 0.29-11 \\
<7-300 \\
<10-200 \\
<1-50 \\
<5-2,900 \\
<20-2,000\end{aligned}$ & $\begin{array}{c}2.7 \\
66 \\
25 \\
3.3 \\
52 \\
290\end{array}$ \\
\hline
\end{tabular}

IMeans are arithmet1c, deviations are standard. 
frequency distributions. For this reason, the geometric mean is the more proper measure of central tendency

for these elements. The frequency distributions for potassium and silicon, on the other hand, are more nearly normal if the data are not transformed to logarithms and the mean is expressed as the arithmetic average.

In geochemical background studies, the magnitude of scatter to be expected around the mean is as important as the mean. In lognormal distributions, the geometric deviation measures this scatter, and this deviation may be used to estimate the range of variation expected for an element in the material being studied. About 68 percent of the samples in a randomly selected suite should fall within the limits $M / D$ and $M \cdot D$, where $M$ represents the geometric mean and $D$ the geometric deviation. About 95 percent should fall between $M / D^{2}$ and $M \cdot D^{2}$, and about 99.7 percent between $M / D^{3}$ and $M \cdot D^{3}$.

The analytical data for some elements include values that are below, or above, the limits of numerical determination, and these values are expressed as less than $(<)$ or greater than $(>)$ a stated value. These data are said to be censored, and for these the mean was computed by using a technique described by Cohen (1959) and applied to geochemical studies by Miesch (1967). This technique requires an adjustment of the summary statistics computed for the noncensored part of the data. The censoring may be so severe in certain sets of data that a reliable adjustment cannot be made; with the data sets used in the present study, however, no such circumstances were encountered. The use of these procedures in censored data to quantify the central tendency may result in estimates of the mean that are lower than the limit of determination. For example, in table 2 the geometric-mean molybdenum concentration in soils from the Eastern United States is estimated to be $0.32 \mathrm{ppm}$, although the lower limit of determination of the analytical method that was used is $3 \mathrm{ppm}$. Use of this procedure permits inclusion of the censored values in the calculation of expected mean concentrations.

The determination ratios in table 2-that is, the ratio of the number of samples in which the element was found in measurable concentrations to the total number of samples-permit the number of censored values, if any, to be found that were used in calculating the mean. This number is found by subtracting the left value in the ratio from the right.

The distribution of the sampling sites and the concentrations of elements determined for samples from the sites are presented on maps of the conterminous United States (figs. 1-47). Figure 1 shows the locations of sites where four elements, bismuth, cadmium, praseodymium, and silver, were found in the samples. These elements were determined too uncommonly for reliable mean concentrations to be calculated. Each of the remaining maps (figs. 2-47) gives the locations where an element was found in a sample from a site and the concentration of the element, shown by a symbol that represents a class of values. By examining the tables of frequency for concentration values of the elements, we were able to divide the ranges of reported values for many elements into five classes so that approximately 20 percent of the values fell into each class. The limited range in values for some elements, however, prohibited the use of more than two or three classes to represent the total distribution. Symbols representing the classes were drawn on the maps by an automatic plotter that was guided by computer classification of the data, including the latitude and longitude of the sampling sites. A histogram on each map gives the frequency distribution of the analytical values, and the assignment of analytical values to each class as represented by symbols.

We were able to obtain analyses of 11 more elements for the 355 samples of phase two of this study than for the 963 samples of phase one because of improved analytical methods and services. These elements are antimony, bromine, carbon, germanium, iodine, rubidium, silicon, sulfur, thorium, tin, and uranium. The constraints of resources and time prohibited analysis of the 963 samples of the first phase for these additional elements. Results of analysis of the plant samples that were collected at all soil-sampling sites are not presented in this report.

Some elements were looked for in all samples but were not found. These elements, analyzed by the semiquantitative spectrographic method, and their approximate lower detection limits, in parts per million, are as follows: gold, 20; hafnium, 100; indium, 10; platinum, 30; palladium, 1; rhenium, 30; tantalum, 200; tellurium, 2,000; and thallium, 50. If lanthanum or cerium were found in a sample, the following elements, with their stated lower detection limits, were looked for in the same sample but were not found: dysprosium, 50; erbium, 50; gadolinium, 50; holmium, 20; lutetium, 30; terbium, 300; and thulium, 20.

\section{DISCUSSION OF RESULTS}

The data presented in this report may reveal evidence of regional variations in abundances of elements in soils or other regoliths; single values or small clusters of values on the maps may have little significance if considered alone. Apparent differences in values shown between certain sampling routes, such as some of those across the Great Plains and the North Central States where high values for cerium, cobalt, gallium, and lead predominate, suggest the possibility of systematic er- 
rors in sampling or in laboratory analysis. Some gross patterns and some of lesser scale, nevertheless, are evident in the compositional variation of regoliths, as shown in figures 2-47.

The lower abundances of some elements (notably aluminum, barium, calcium, magnesium, potassium, sodium, and strontium) in regoliths of the Eastern United States, and the greater abundances of the heavy metals in the same materials of the Western United States indicate a regional pattern of the largest scale. This visual observation of the maps can be substantiated by examining the mean concentrations for these two regions given in table 2 . The abundances of these elements differ markedly on either side of a line extending from western Minnesota southward through east-central Texas. This line is generally from the 96th to 97th meridian, and corresponds to the boundary proposed by Marbut (1935, p. 14), which divides soils of the United States into two major groups-the pedalfers that lie to the east, and the pedocals to the west. Marbut (1928) attributed the major differences in chemical and physical qualities of these two major groups to the effects of climate on soils. A line approximating the 96th meridian also separates the Orders, Suborders, and Great Groups of moist-to-wet soils in the Eastern United States from the same categories of dry soils that lie to the west, as mapped by the [U.S.] Soil Conservation Service (1969). As shown in table 2, soils of the Western United States have the highest mean values for all elements considered in this report except for antimony, boron, bromine, mercury, neodymium, selenium, titanium, and zirconium. The differences, however, probably are not significant for these latter elements, except for zirconium.

Superimposed upon this large-scale compositional variation pattern are several features of intermediate scale. Perhaps the most notable of these are the low concentrations of many elements in soils of the Atlantic Coastal Plain. Soils of the Pacific Northwest are high in concentrations of aluminum, cobalt, iron, scandium, and vanadium, but low in boron, and soils of the Rocky Mountain region tend to be high in copper, lead, and zinc.

Several small-scale patterns of compositional variation can be noted, among them the high mercury concentrations in surficial materials from the Gulf Coast of eastern Texas, Louisiana, Mississippi, Alabama, and northwest Florida, and a similar pattern on the Atlantic Coast in Connecticut, Massachusetts, and Maine. High phosphorus values occur in soils along a line extending west across Utah and Nevada to the coast of California, then south-east in California and Arizona. At the State level, Florida shows the most striking pattern by hav- ing low soil concentrations of most of the elements considered in this study.

The concentrations of certain elements do not show well-defined patterns of distribution, and the regional concentrations of some other elements cannot be evaluated because they were not present in detectable amounts in most of the samples, or because the sampling density was insufficient. The degree of confidence in regional patterns of element abundance is expected to be in direct proportion to the number of samples analyzed from the region. As the observed patterns become smaller, the probability increases that the characteristics that form the patterns are the results of chance.

Some features of element-abundance patterns probably reflect geologic characteristics of the areas that the soils overlie. Samples from most of the regoliths overlying basic volcanic rocks of Washington and Oregon contained higher than average concentrations of iron and other elements, as mentioned earlier. A few soil samples with high phosphorus content are associated with phosphate deposits in Florida, and a single sample in Michigan with high copper content is known to be of soil that occurs over a copper deposit.

These data do not provide obvious evidences of northsouth trends in elemental compositions that might be expected to relate to differences in temperature regimes under which the surficial materials developed. There is, moreover, no consistent evidence of significant differences in element abundances between glaciated and nonglaciated areas (the general area of continental glaciation includes the northern tier of States from Montana to Maine and south in places to about lat $40^{\circ} \mathrm{N}$.; see fig. 1 ).

The world averages of abundance for some elements in soils, as given by Vinogradov (1959) and by others (table 1), do not correspond to the averages of abundance for these elements in the soils of the United States, according to the data presented in this report. The world averages are too low for the concentrations of boron, calcium, cerium, lead, magnesium, potassium, and sodium in United States soils and other surficial materials, and too high for beryllium, chromium, gallium, manganese, nickel, phosphorus, titanium, vanadium, and yttrium.

The stability of values for concentrations of most elements seems to be satisfactory because the addition of analytical values for 355 samples of phase two of the study to values for 963 samples of the first phase did not significantly change the geometric means and deviations of element abundance that were reported earlier (Shacklette, Boerngen, and Turner, 1971; Shacklette, Hamilton, and others, 1971; Shacklette and others, 
1973, 1974). Although additional sampling of the same type as reported here might give a clearer picture of small-to-intermediate element-abundance patterns, mean values reported herein most likely would not change significantly.

\section{REFERENGES CITED}

Bear, F. E., ed., 1964, Chemistry of the soil [2d ed.]: New York, Reinhold Publishing Corp., 515 p.

Boerngen, J. G., and Shacklette, H. T., 1980, Chemical analyses of fruits, vegetables, and their associated soils from areas of commercial production in the conterminous United States: U.S. Geological Survey Open-File Report 80-84, 134 p.

1981, Chemical analysis of soils and other surficial materials of the conterminous United States: U.S. Geological Survey OpenFile Report 81-197, 143 p.

Brooks, R. R., 1972, Geobotany and biogeochemistry in mineral exploration: New York, Harper and Row, $290 \mathrm{p}$.

Cannon, H. L., and Bowles, J. M., 1962, Contamination of vegetation by tetraethyl lead: Science, v. 137, no. 3532, p. 765-766.

Cohen, A. C., Jr., 1959, Simplified estimators for the normal distribution when samples are singly censored or truncated: Technometrics, v. 1, no. 3, p. 217-237.

Connor, J. J., and Shacklette, H. T., 1975, Background geochemistry of some rocks, soils, plants, and vegetables in the conterminous United States, with sections on Field studies by R. J. Ebens, J. A. Erdman, A. T. Miesch, R. R. Tidball, and H. A. Tourtelot: U.S. Geological Survey Professional Paper 574-F, 168 p.

Ebens, R. J., Erdman, J. A., Feder, G. L., Case, A. A., and Selby, L. A., 1973, Geochemical anomalies of a claypit area, Callaway County, Missouri, and related metabolic imbalance in beef cattle: U.S. Geological Survey Professional Paper 807, 24 p.

Ebens, R. J., and Shacklette, H. T., 1981, Geochemistry of some rocks, mine spoils, stream sediments, soils, plants, and waters in the western energy region of the conterminous United States, with sections on Field studies by B. M. Anderson, J. G. Boerngen, J. J. Connor, W. E. Dean, J. A. Erdman, G. L. Feder, L. P. Gough, J. R. Herring, T. K. Hinkley, J. R. Keith, R. W. Klusman, J. M. MeNeal, C. D. Ringrose, R. C. Severson, and R. R. Tidball: U.S. Geological Survey Professional Paper $1237,173 \mathrm{p}$.

Erdman, J. A., Shacklette, H. T., and Keith, J. R., 1976a, Elemental composition of selected native plants and associated soils from major vegetation-type areas in Missouri: U.S. Geological Survey Professional Paper 954-C, p. C1-C87.

1976b, Elemental composition of corn grains, soybean seeds, pasture grasses, and associated soils from selected areas in Missouri: U.S. Geological Survey Professional Paper 954-D, p. D1D23.

Goldschmidt, V. M., 1954, Geochemistry: Oxford, Clarendon Press, $730 \mathrm{p}$.

Hawkes, H. E., 1957, Principles of geochemical prospecting: U.S. Geological Survey Bulletin 1000-F, p. 225-355.

Hawkes, H. E., and Webb, J. S., 1962, Geochemistry in mineral exploration: New York, N. Y., and Evanston, Ill., Harper and Row, $415 p$

Huffman, Claude, Jr., and Dinnin, J. I., 1976, Analysis of rocks and soil by atomic absorption spectrometry and other methods, in Miesch, A. T., Geochemical survey of Missouri-Methods of sampling, laboratory analysis, and statistical reduction of data: U.S. Geological Survey Professional Paper 954-A, p. 12-14.
Jackson, M. L., 1964, Chemical composition of soils, in Bear, F. E., ed., Chemistry of the soil [2d ed.]: New York, Reinhold Publishing Corp., p. 71-141.

Levinson, A. A., 1974, Introduction to exploration geochemistry: Calgary, Applied Publishing, Ltd., $612 \mathrm{p}$.

Marbut, C. F., 1928, Classification, nomenclature, and mapping of soils in the United States-The American point of view: Soil Science, v. 25, p. 61-70.

-1935, Soils of the United States, pt. 3 of Atlas of American agriculture: Washington, D.C., U.S. Government Printing Office, $98 \mathrm{p}$.

McMurtrey, J. E., Jr., and Robinson, W. O., 1938, Neglected soil constituents that affect plant and animal development, in Soils and men-Yearbook of Agriculture 1938: Washington, D.C., U.S. Government Printing Office, p. 807-829.

Miesch, A. T., 1967, Methods of computation for estimating geochemical abundance: U.S. Geological Survey Professional Paper 574-B, $15 \mathrm{p}$.

Millard, H. T., Jr., 1975, Determination of uranium and thorium in rocks and soils by the delayed neutron technique, in U.S. Geological Survey, Geochemical survey of the western coal region, second annual progress report, July 1975: U.S. Geological Survey Open-File Report 75-436, p. 79-81.

1976, Determination of uranium and thorium in U.S.G.S. standard rocks by the delayed neutron technique, in Flanagan, $F$. J., ed. and compiler, Description and analyses of eight new U.S.G.S. rock standards: U.S. Geological Survey Professional Paper 840, p. 61-65.

Mitchell, R. L., 1964, Trace elements in soils, in Bear, F. E., ed., Chemistry of the soil [2d ed.]: New York, Reinhold Publishing Corp., p. 320-368.

Myers, A. T., Havens, R. G., and Dunton, P. J., 1961, A spectrochemical method for the semiquantitative analysis of rocks, minerals, and ores: U.S. Geological Survey Bulletin 1084-I, p. 207-229.

Neiman, H. G., 1976, Analysis of rocks, soils, and plant ashes by emission spectroscopy, in Miesch, A. T., Geochemical survey of Missouri-Methods of sampling, laboratory analysis, and statistical reduction of data: U.S. Geological Survey Professional Paper 594-A, p. 14-15.

Rankama, K. K., and Sahama, T. G., 1955, Geochemistry: Chicago, Chicago University Press, $912 \mathrm{p}$.

Robinson, W. O., 1914, The inorganic composition of some important American soils: U.S. Department of Agriculture Bulletin 122, $27 \mathrm{p}$.

Robinson, W. O., Steinkoenig, L. A., and Fry, W. H., 1917, Variation in the chemical composition of soils: U.S. Department of Agriculture Bulletin 551, $16 \mathrm{p}$.

Rose, A. W., Hawkes, H. E., and Webb, J. S., 1979, Geochemistry in mineral exploration [2d ed.]: London, Academic Press, $658 \mathrm{p}$.

Shacklette, H. T., 1980, Elements in fruits and vegetables from areas of commercial production in the conterminous United States: U.S. Geological Survey Professional Paper 1178, 149 p.

Shacklette, H. T., Boerngen, J. G., Cahill, J. P., and Rahill, R. L., 1973, Lithium in surficial materials of the conterminous United States and partial data on cadmium: U.S. Geological Survey Circular $673,8 \mathrm{p}$.

Shacklette, H. T., Boerngen, J. G., and Keith, J. R., 1974, Selenium, fluorine, and arsenic in surficial materials of the conterminous United States: U.S. Geological Survey Circular 692, 14 p.

Shacklette, H. T., Boerngen, J. G., and Turner, R. L., 1971, Mercury in the environment-Surficial materials of the conterminous 
United States: U.S. Geological Survey Circular 644, 5 p.

Shacklette, H. T., Hamilton, J. C., Boerngen, J. G., and Bowles, J. M., 1971, Elemental composition of surficial materials in the conterminous United States: U.S. Geological Survey Professional Paper 574-D, $71 \mathrm{p}$.

Shacklette, H. T., Sauer, H. I., and Miesch, A. T., 1970, Geochemical environments and cardiovascular mortality rates in Georgia: U.S. Geological Survey Professional Paper 574-C, 39 p.

Sichel, H. S., 1952, New methods in the statistical evaluation of mine sampling data: Institute of Mining and Metallurgy Transactions, v. 61, p. 261-288.

Siegel, F. R., 1974, Applied geochemistry: New York, John Wiley and Sons, $353 \mathrm{p}$.

Swain, D. J., 1955, The trace-element content of soils: England Commonwealth Agricultural Bureau, Commonwealth Bureau of Soil Science Technical Communication 48, $157 \mathrm{p}$.

Tidball, R. R., 1976, Chemical variation of soils in Missouri associated with selected levels of the Soil Classification System: U.S. Geological Survey Professional Paper 954-B, 16 p.

1983a, Geography of soil geochemistry of Missouri agricultural soils, in Geochemical survey of Missouri: U.S. Geological Survey Professional Paper 954-H, in press.

$1983 \mathrm{~b}$, Geochemical classification by factor analysis of Missouri agricultural soils, in Geochemical survey of Missouri: U.S. Geological Survey Professional Paper 954-I, in press.

U.S. Geological Survey, 1974, Geochemical survey of the western coal regions, first annual progress report, July 1974: U.S. Geological Survey Open-File Report 74-250, 38 p.

-1975 , Geochemical survey of the western coal regions, second annual progress report, July 1975: U.S. Geological Survey OpenFile Report 75-436, 132 p.
-1976, Geochemical survey of the western energy regions, third annual progress report, July 1976: U.S. Geological Survey OpenFile Report 76-729, 138 p. + appendix, 44 p.

1977, Geochemical survey of the western energy regions, fourth annual progress report, July 1977: U.S. Geological Survey Open-File Report 77-872, 207 p.

1978, Geochemical survey of the western energy regions, fifth annual progress report, July 1978: U.S. Geological Survey OpenFile Report 78-1105, $194 \mathrm{p}$.

[U.S.] Soil Conservation Service, 1969, Distribution of principal kinds of soils-Orders, Suborders, and Great Groups, in National Atlas of the United States of America: U.S. Geological Survey, Sheet $86,2 \mathrm{p}$.

Vaughn, W. W., 1967, A simple mercury vapor detector for geochemical prospecting: U.S. Geological Survey Circular 540, 8 p.

Vinogradov, A. P., 1959, The geochemistry of rare and dispersed chemical elements in soils [2d ed., revised and enlarged]: New York, Consultants Bureau Enterprises, 209 p.

Wahlberg, J. S., 1976, Analysis of rocks and soils by X-ray fluorescence, in Miesch, A. T., Geochemical survey of MissouriMethods of sampling, laboratory analysis, and statistical reduction of data: U.S. Geological Survey Professional Paper 954-A, p. 11-12.

Ward, F. N., Lakin, H. W., Canney, F. C., and others, 1963, Analytical methods used in geochemical exploration by the U.S. Geological Survey: U.S. Geological Survey Bulletin 1152, 100 p.

Webb, J. S., 1953, A review of American progress in geochemical prospecting and recommendations for future British work in this field: Institute of Mining and Metallurgy Transactions, v. 62, pt. 7, p. 321-348. 
ILLUSTRATIONS 


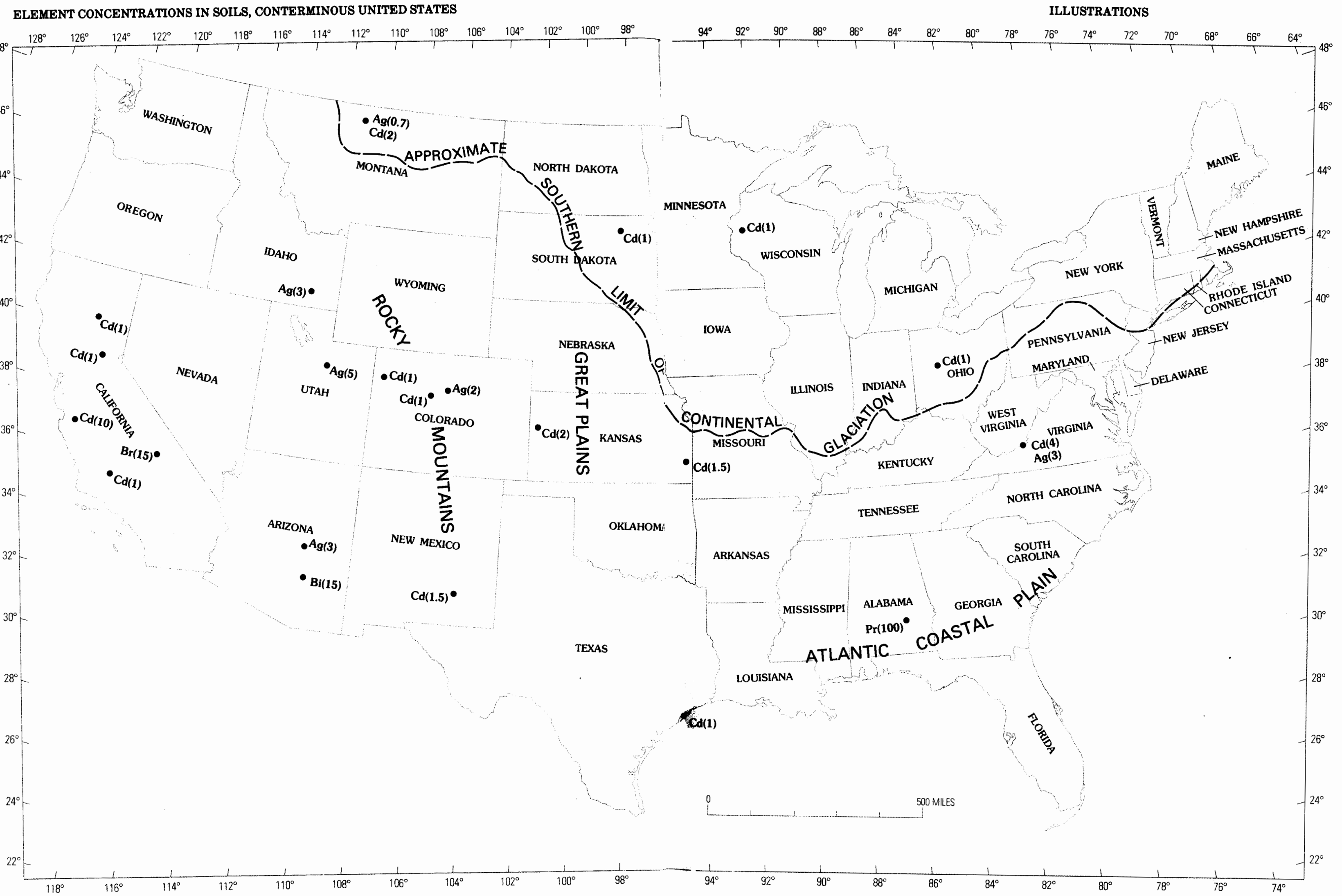

FIGURE 1.-Location of sampling sites in the conterminous United States where elements not commonly detected in surficial deposits were found, and the amounts of the elements present, in parts per million, in parentheses. 


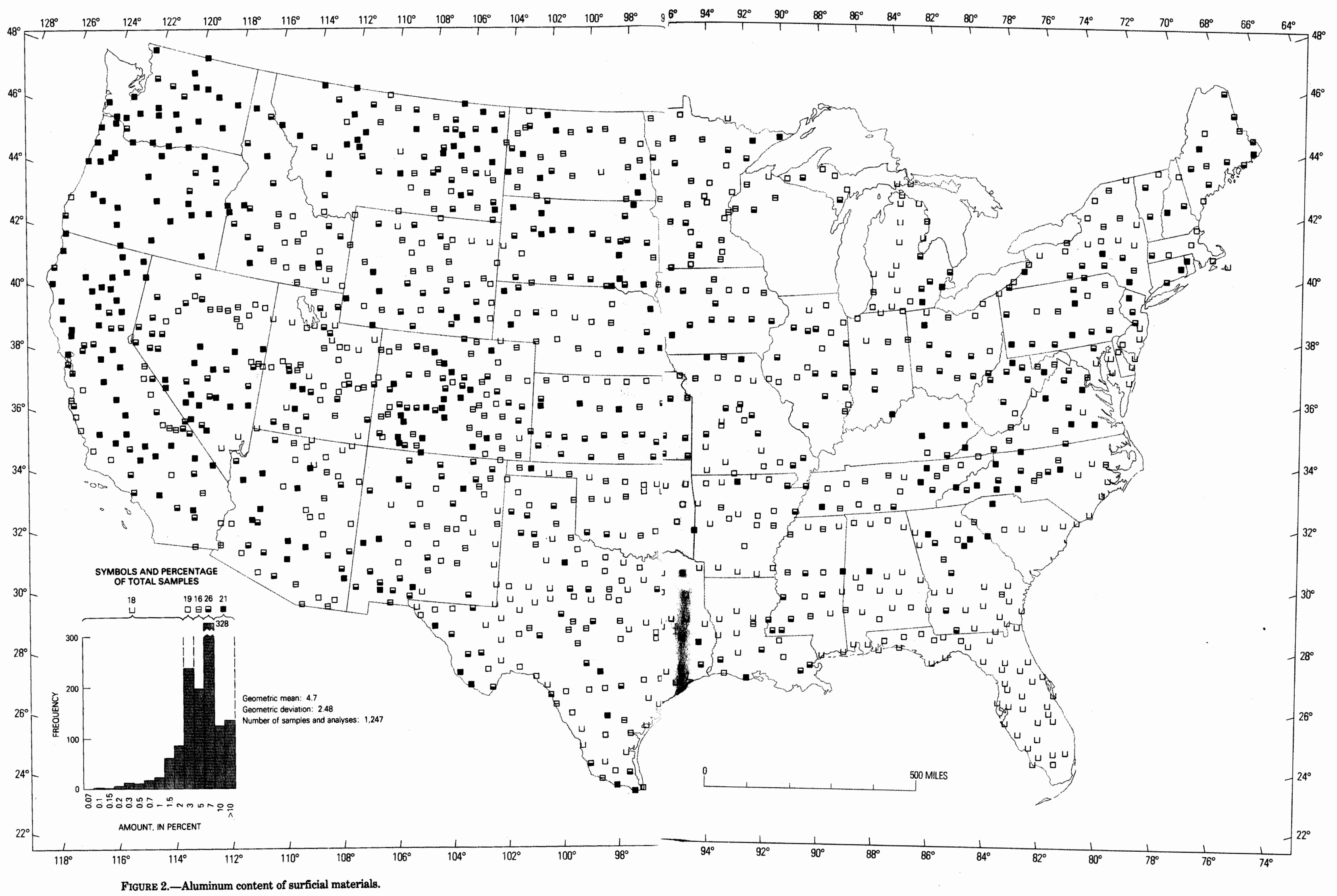




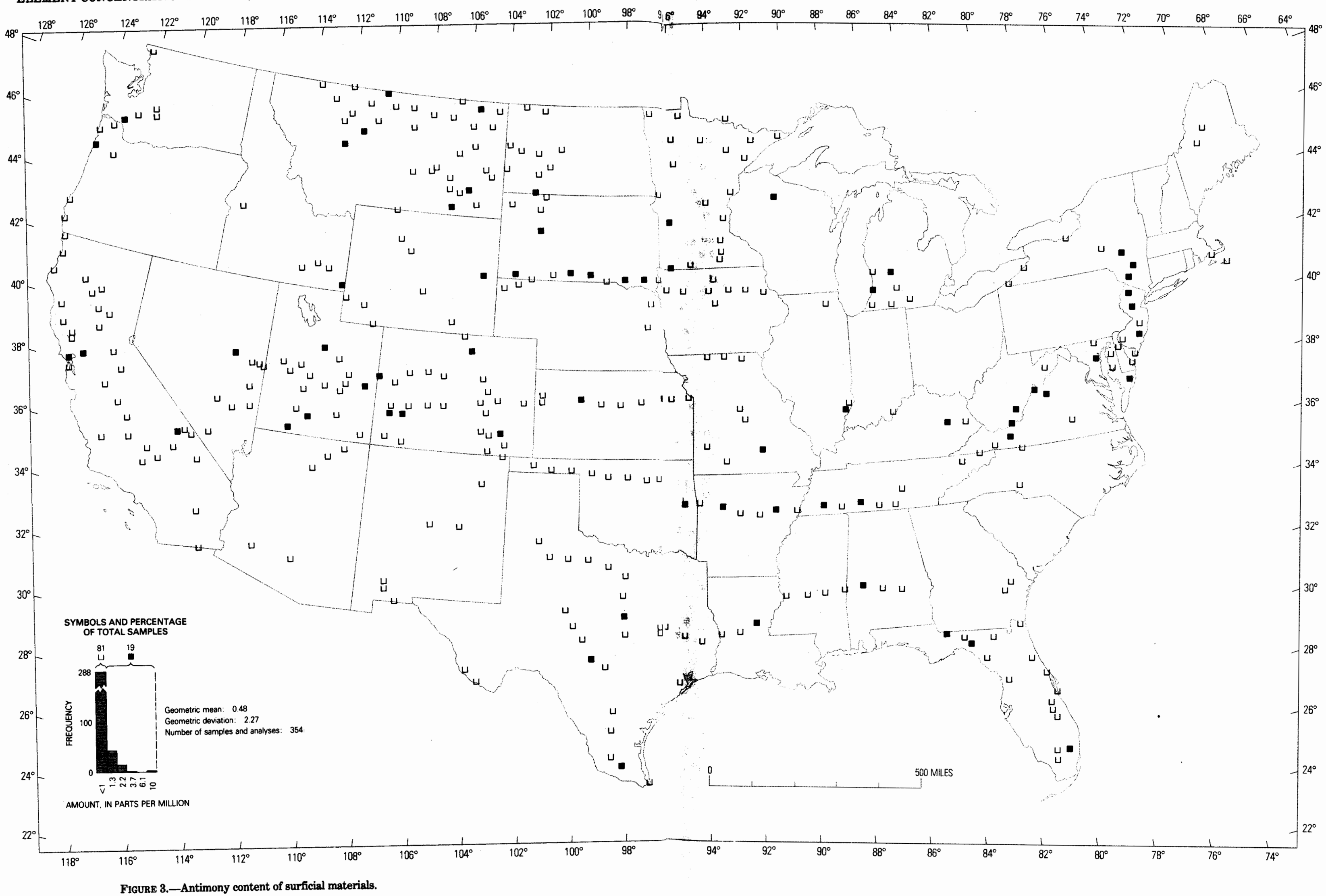




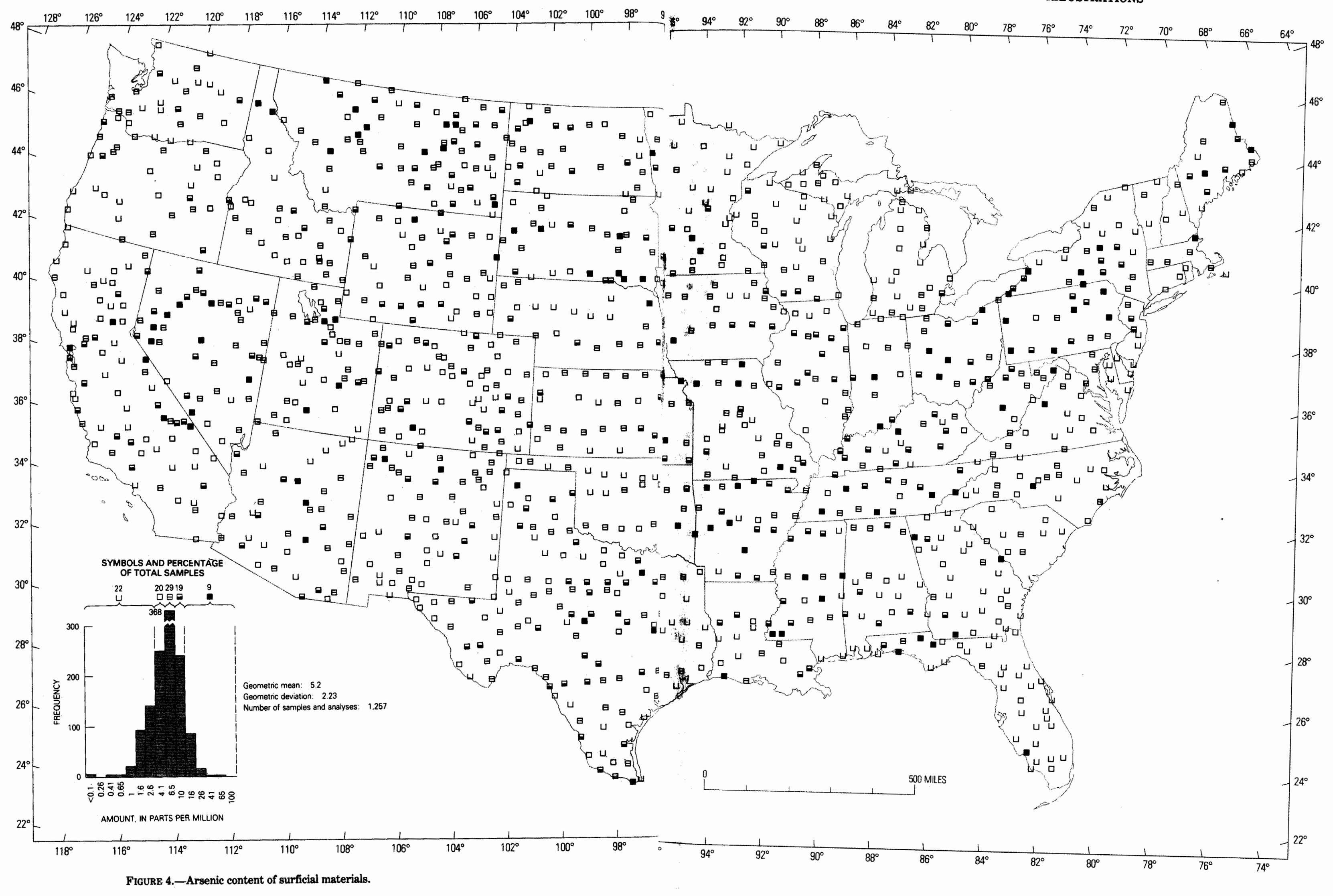




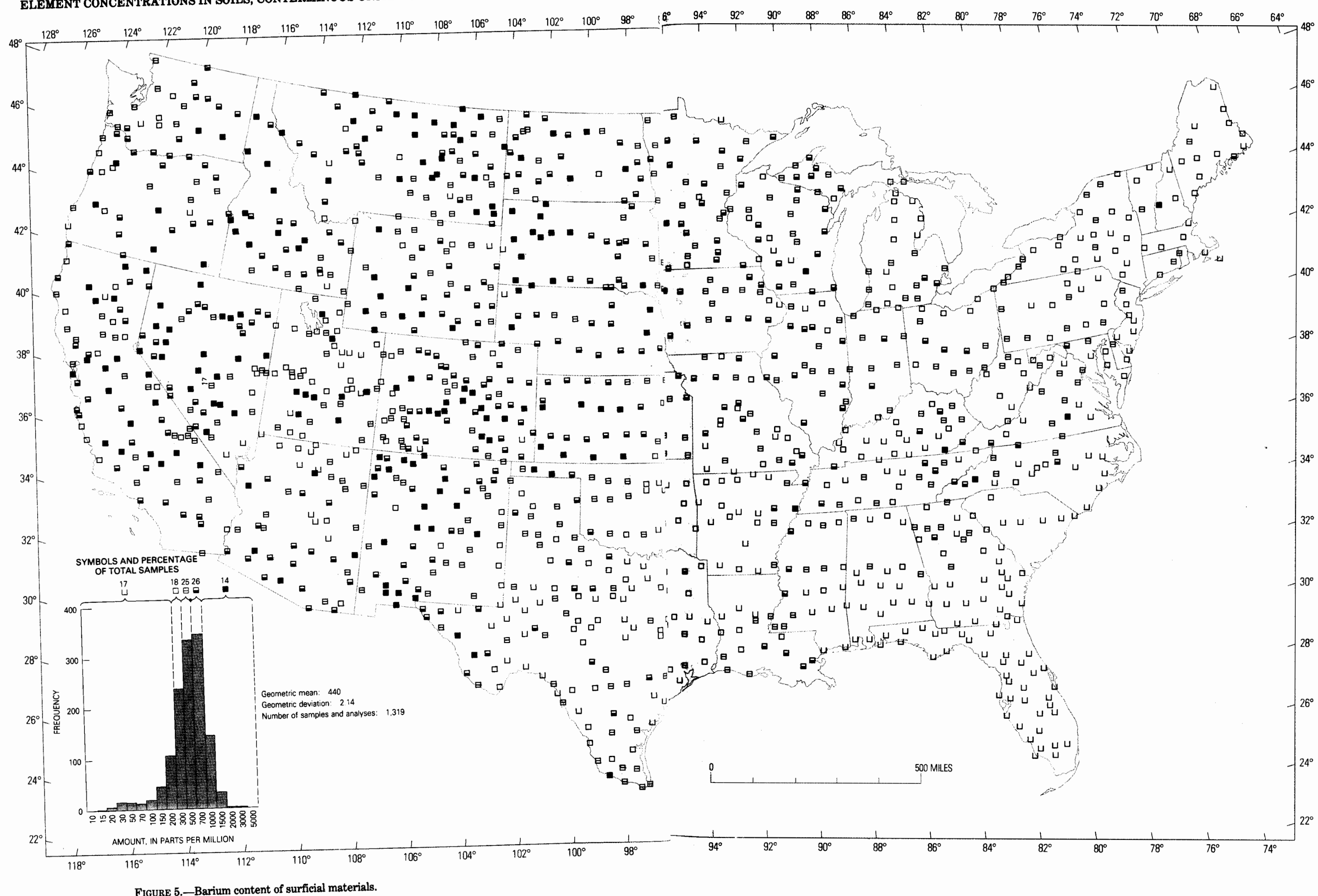




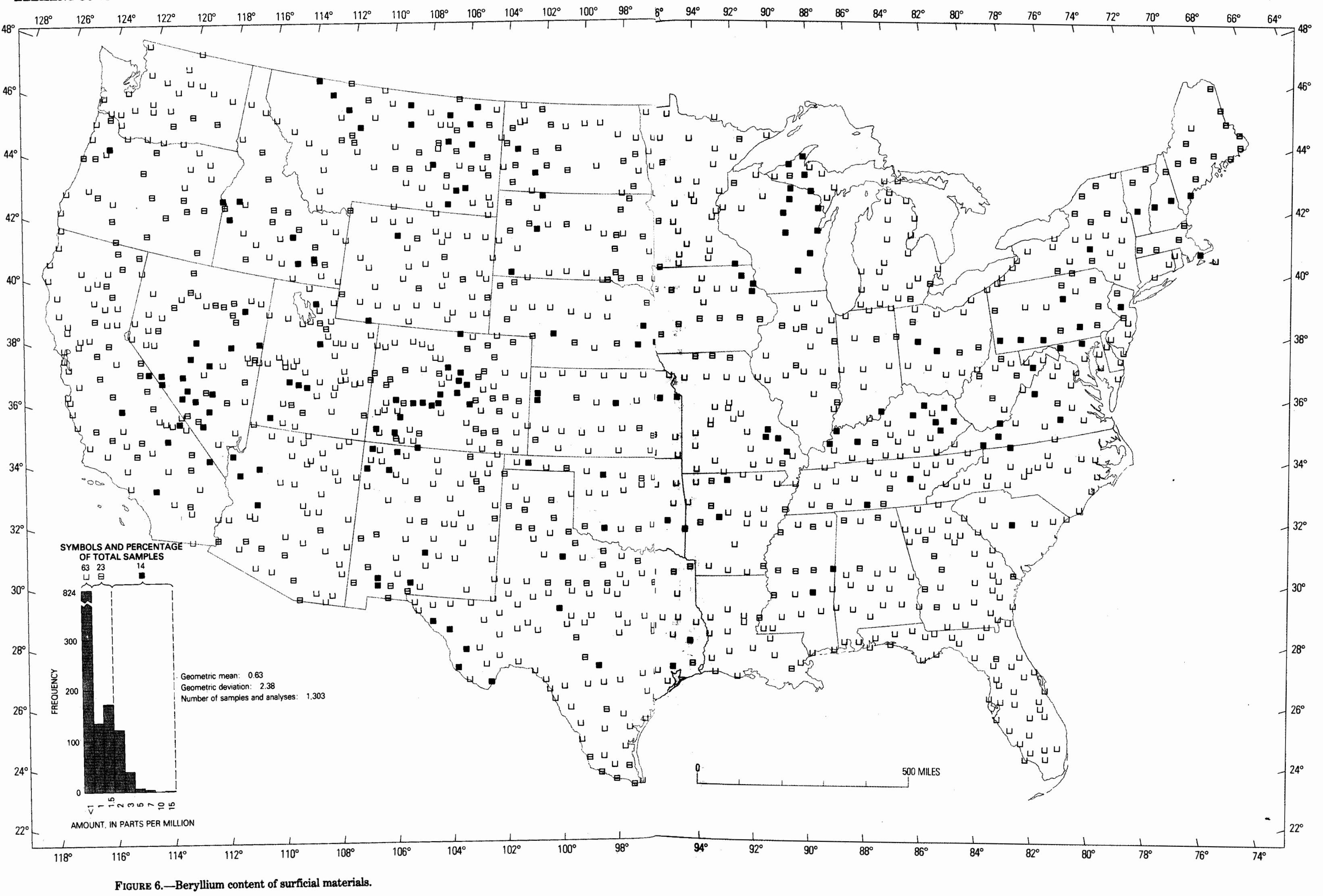




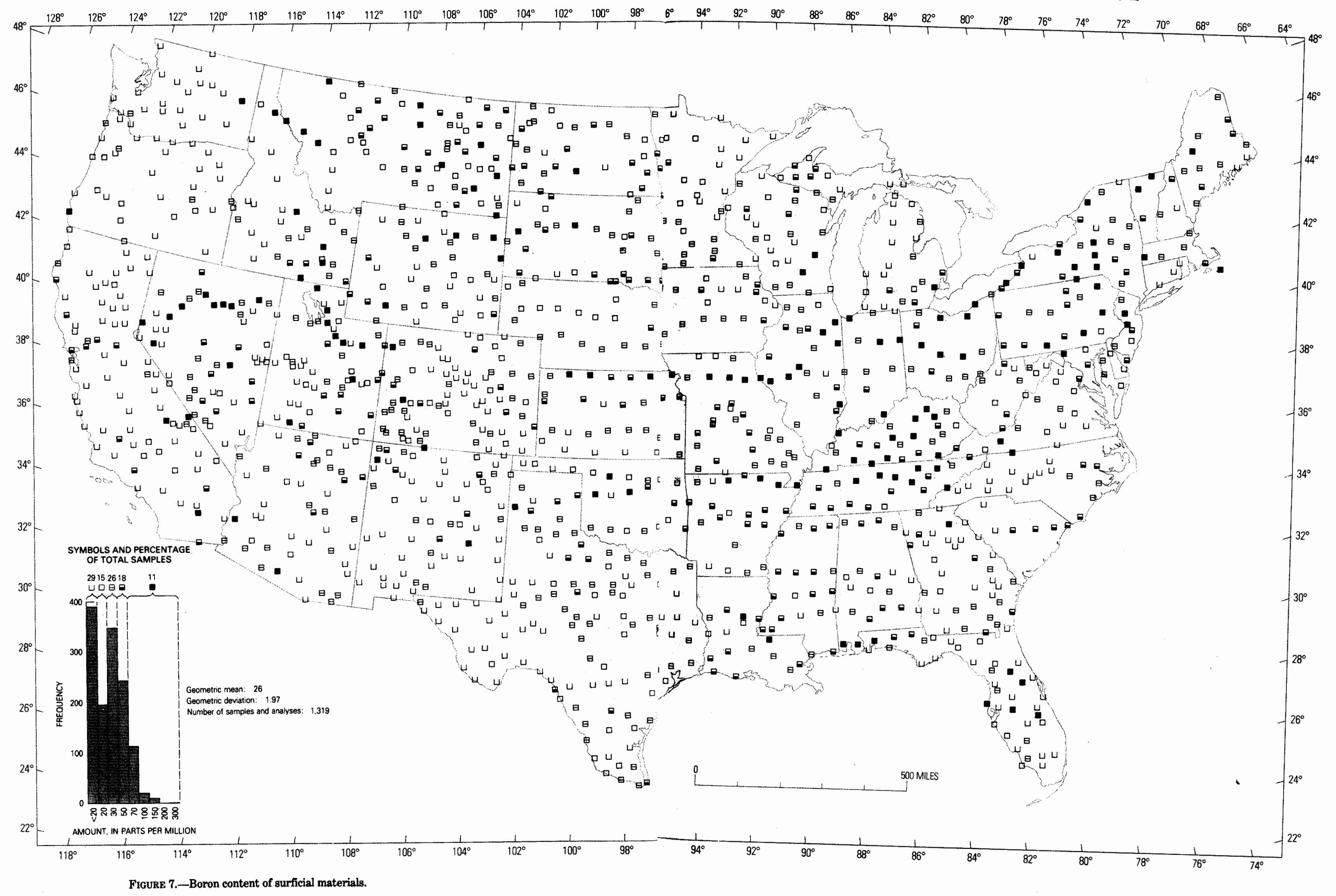




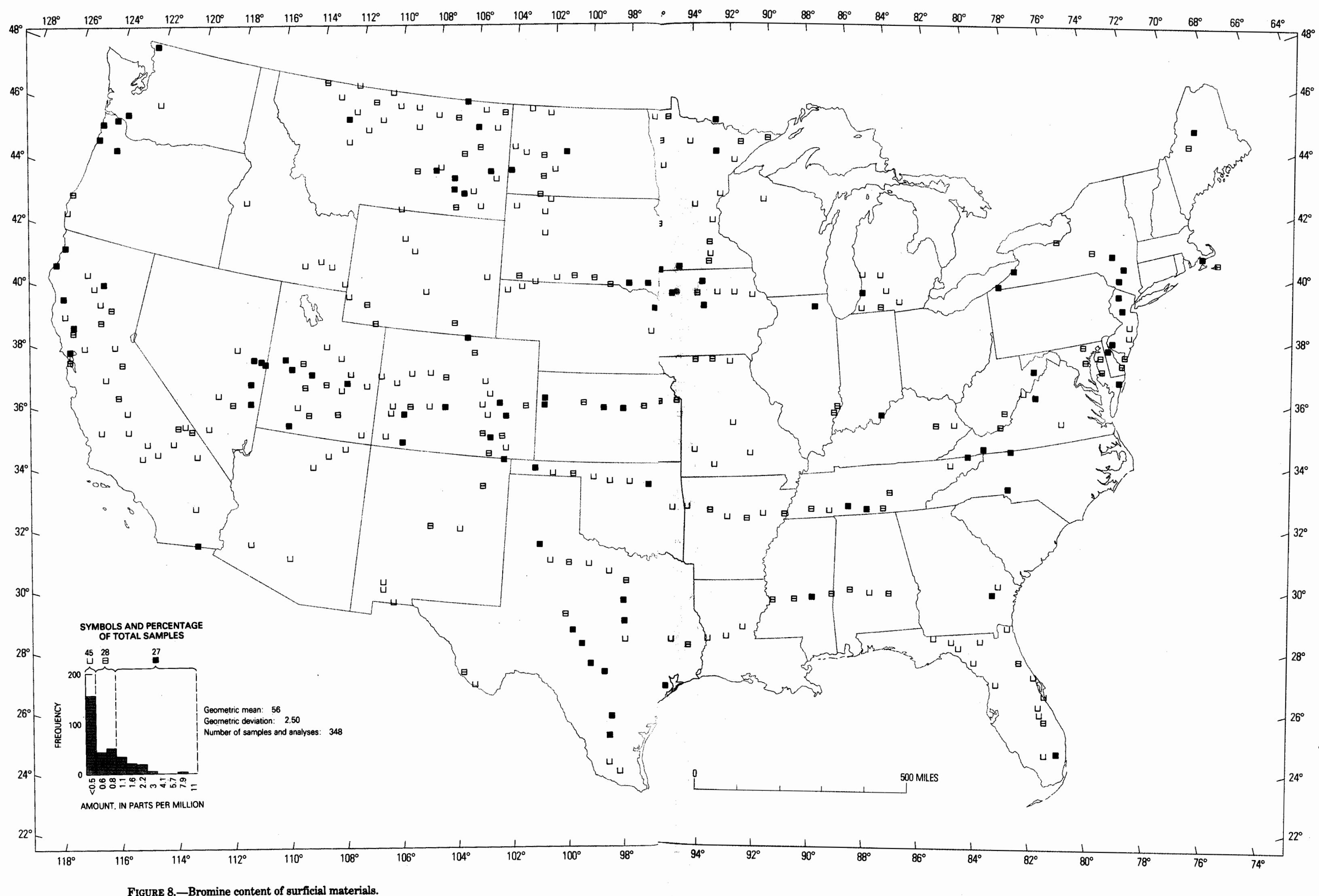




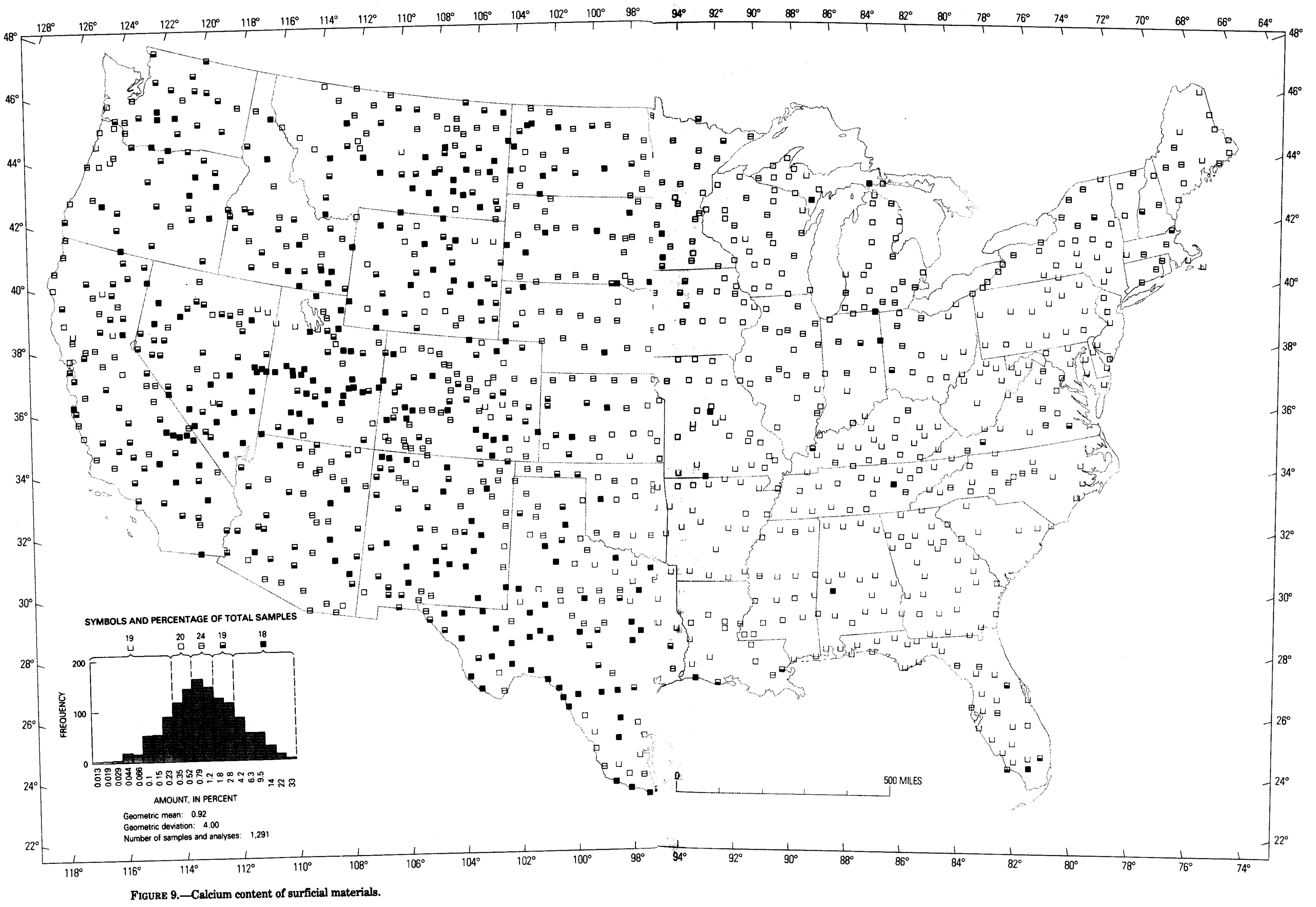




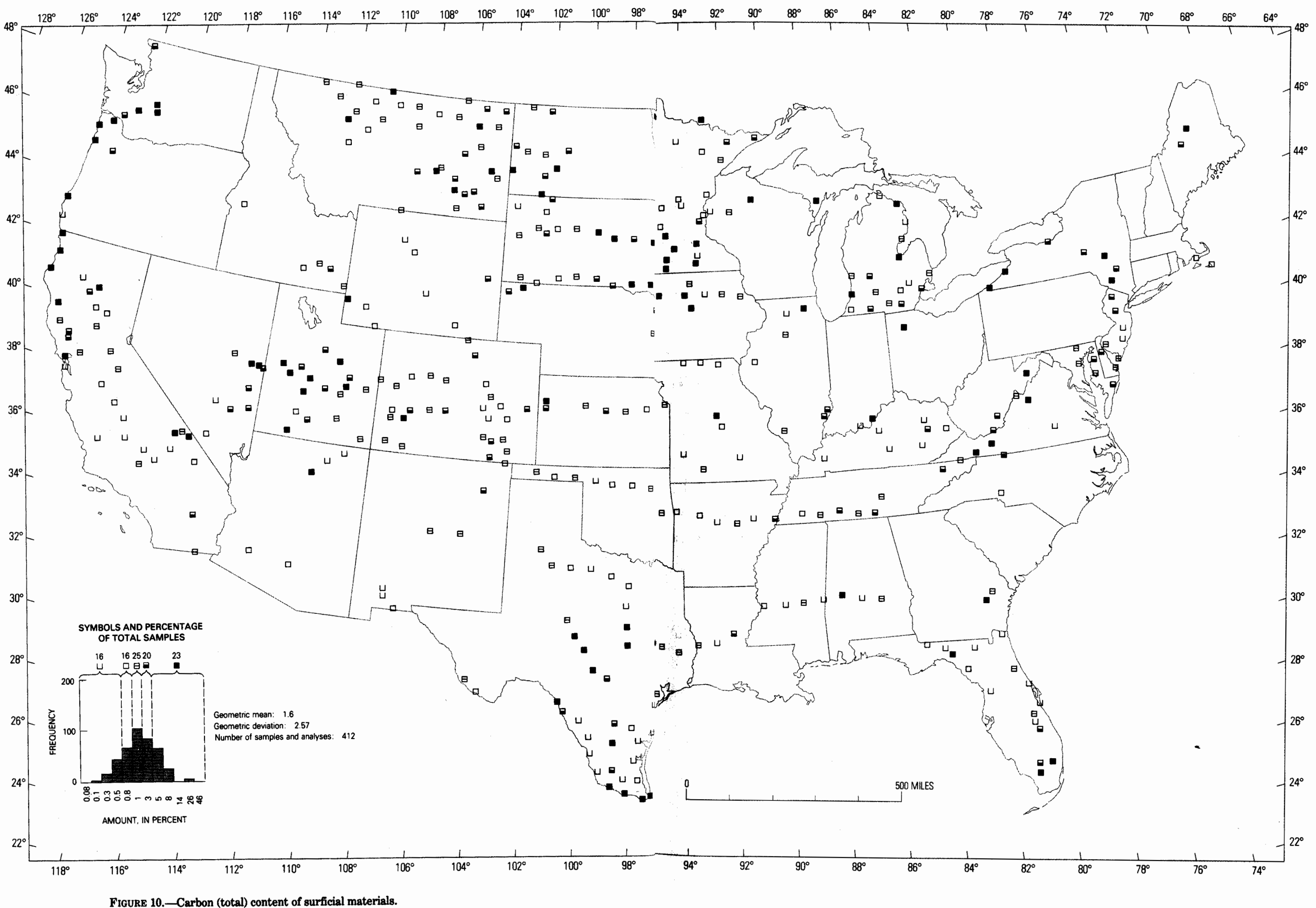




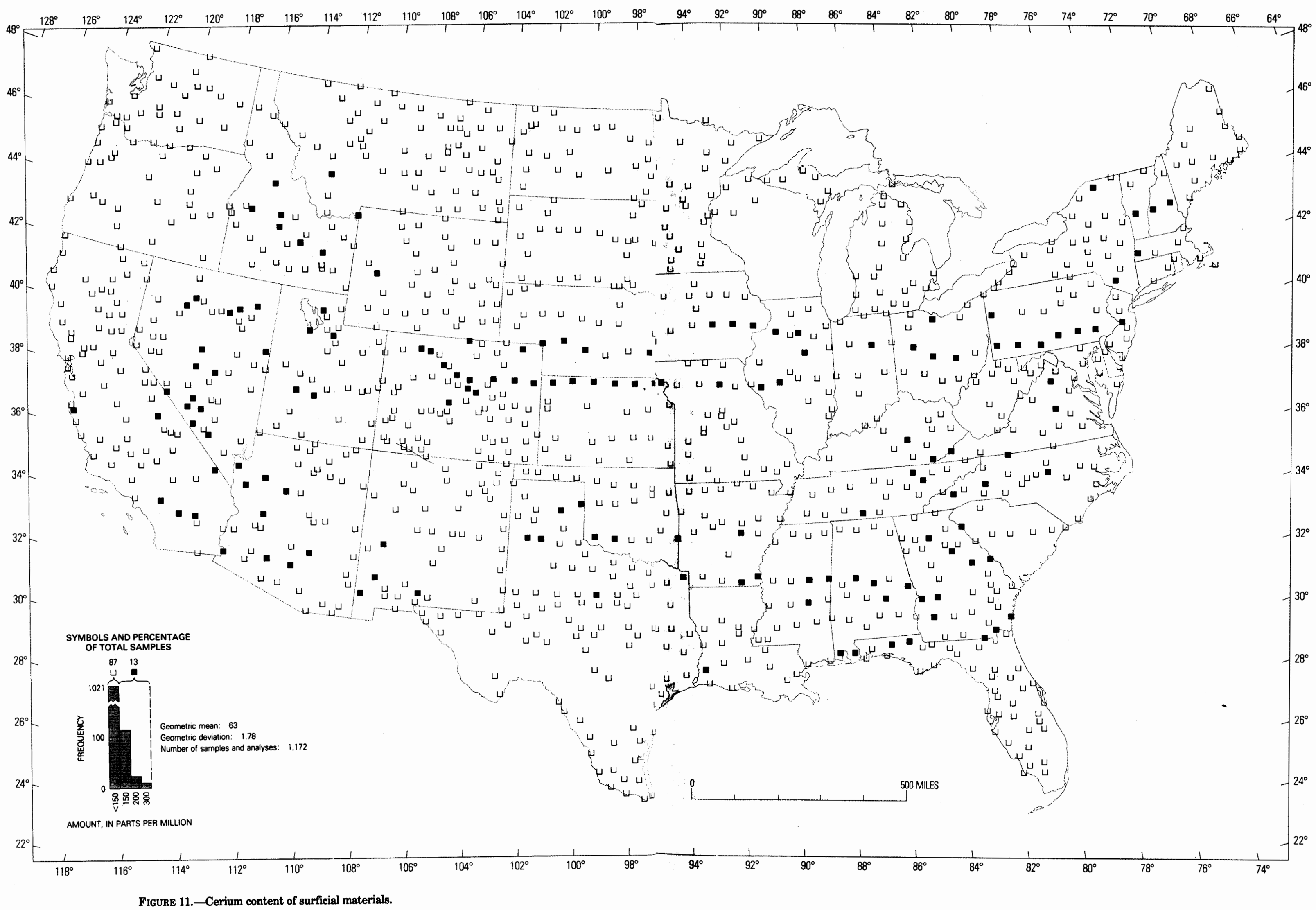




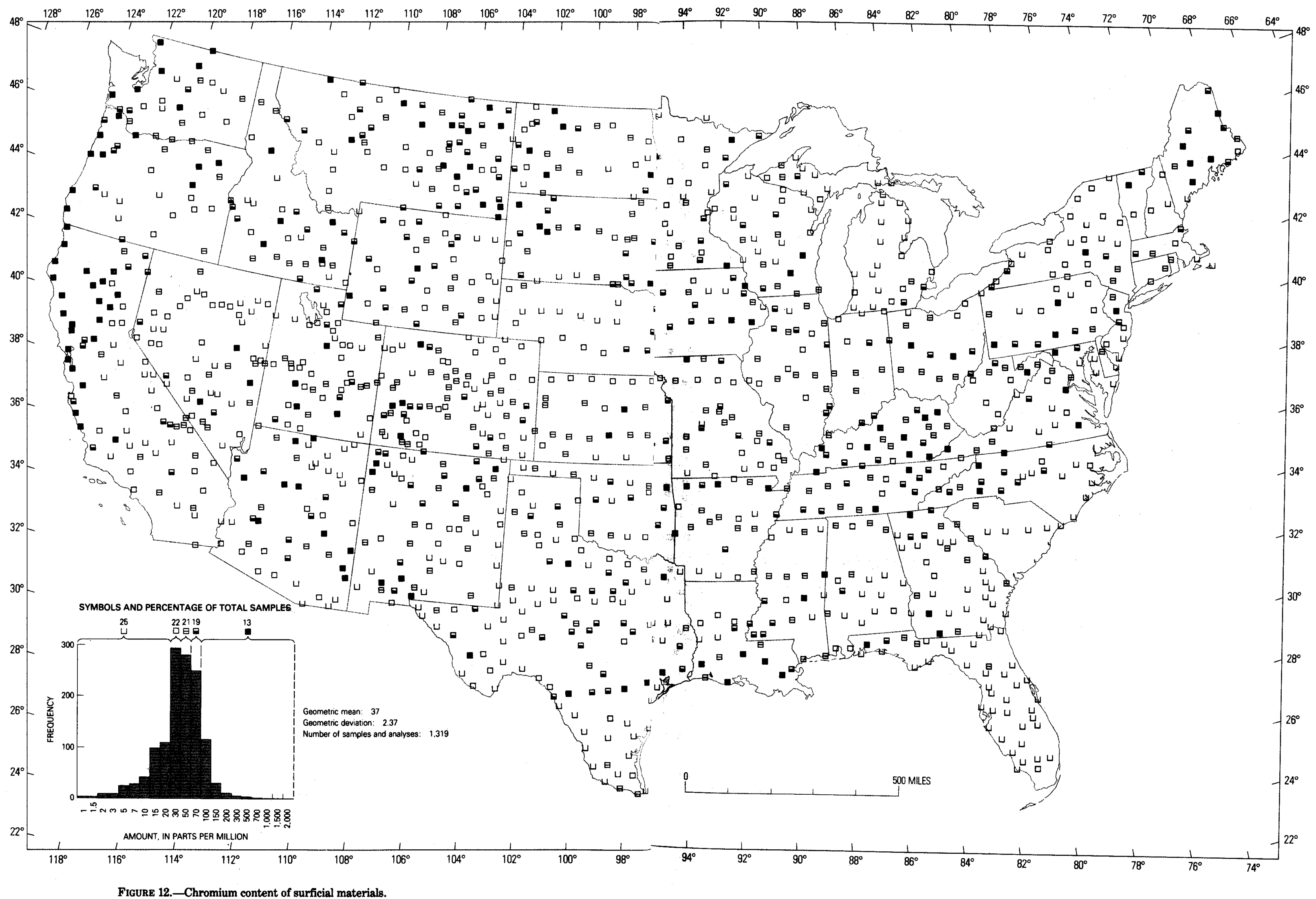




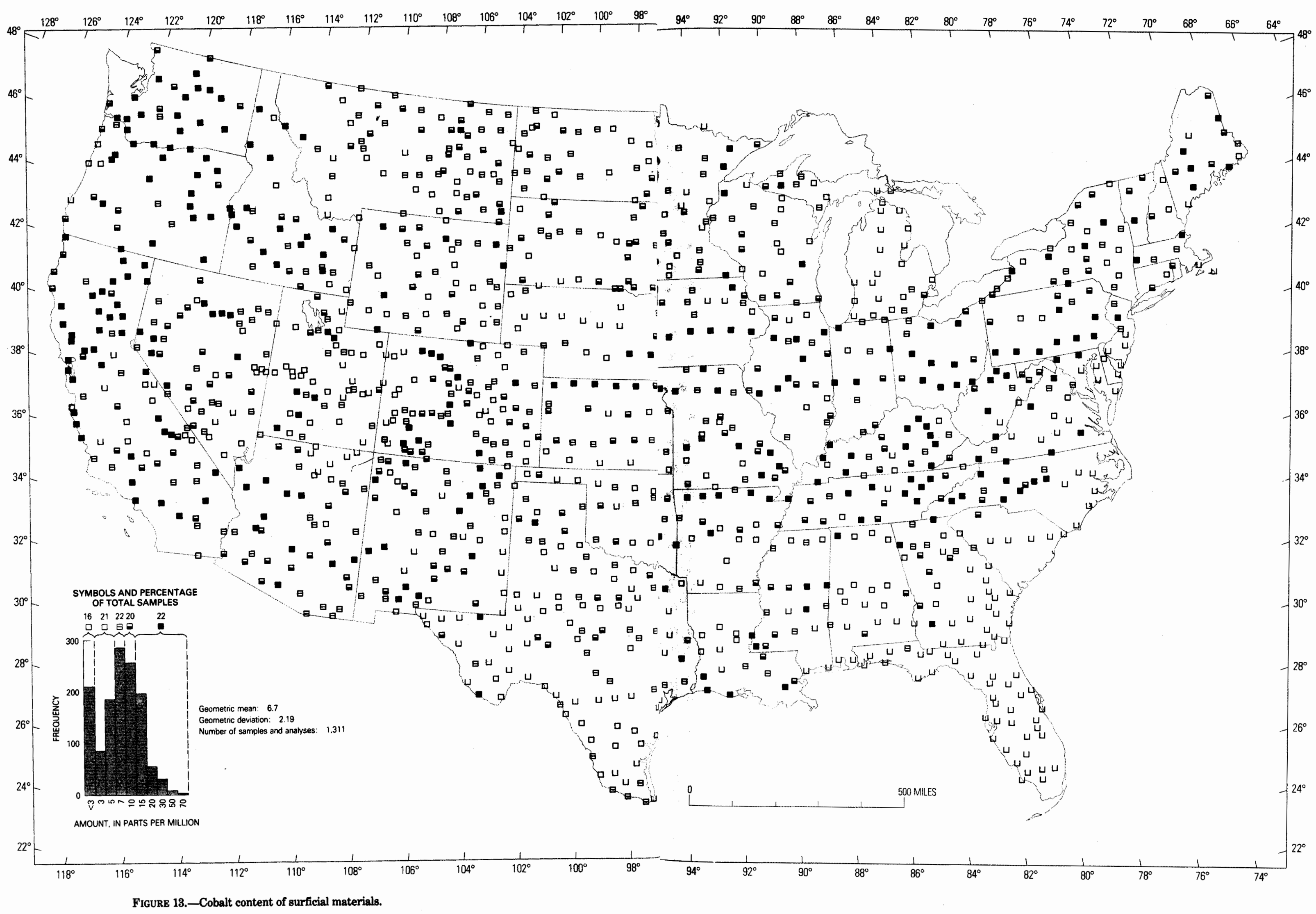




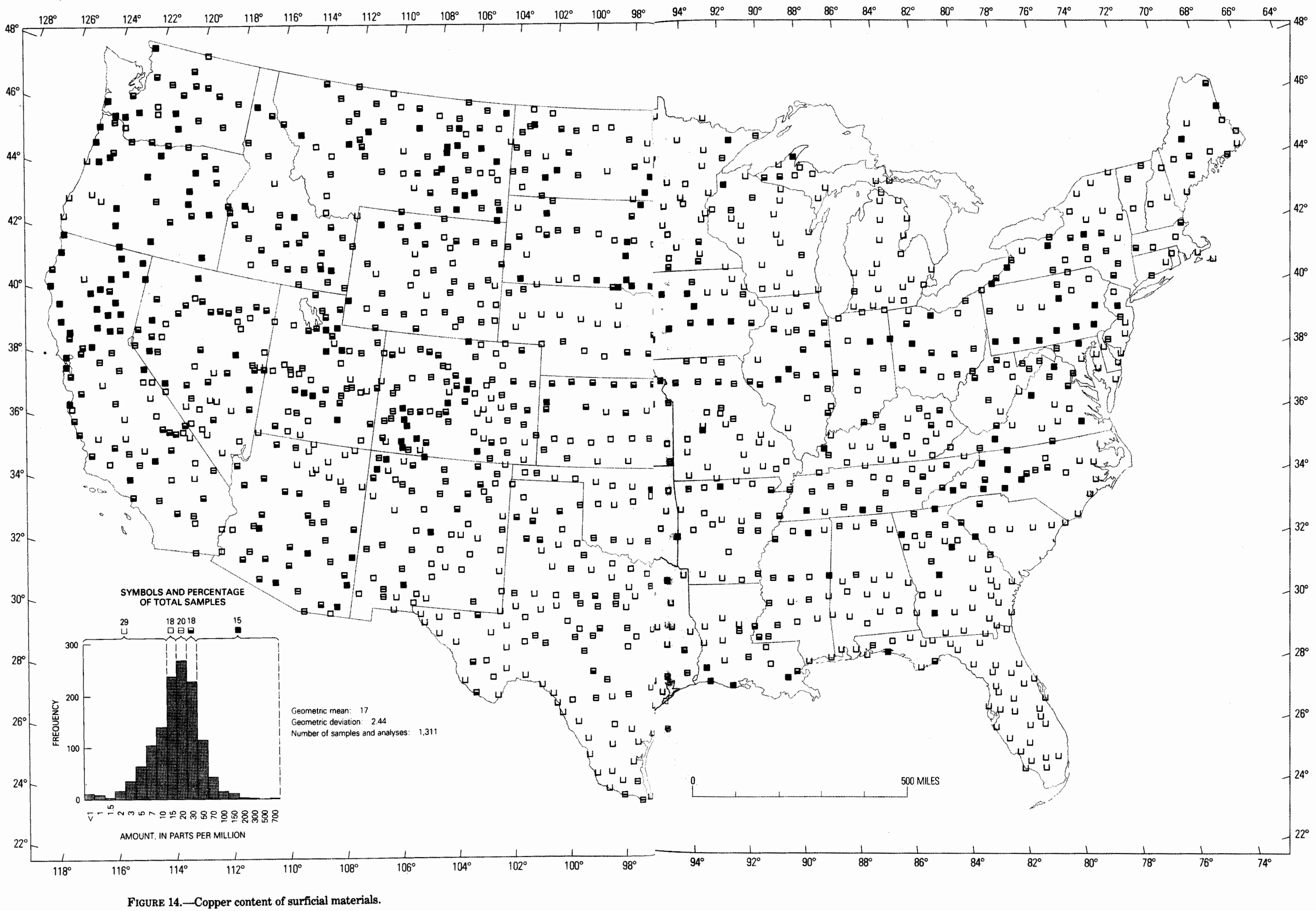




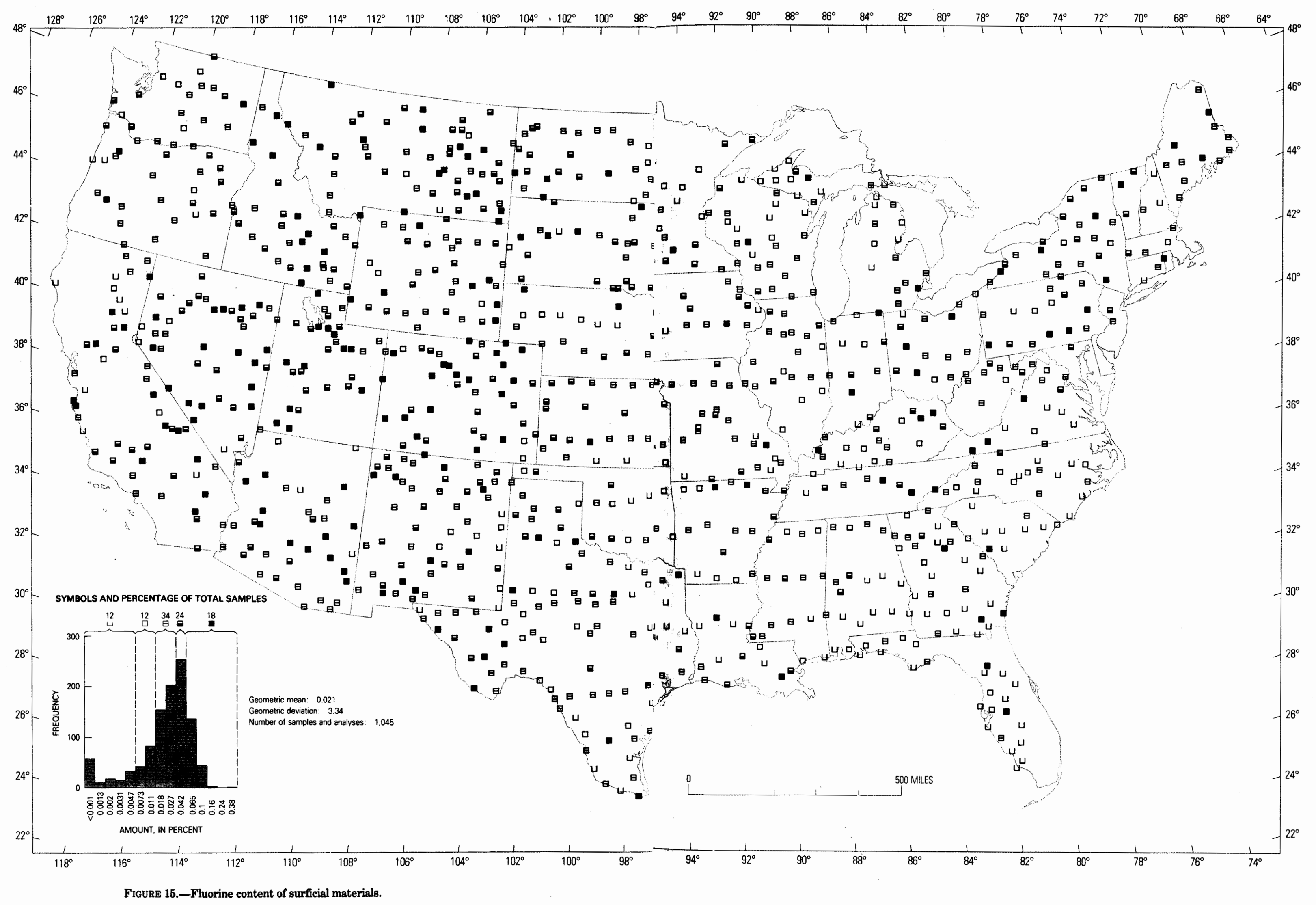




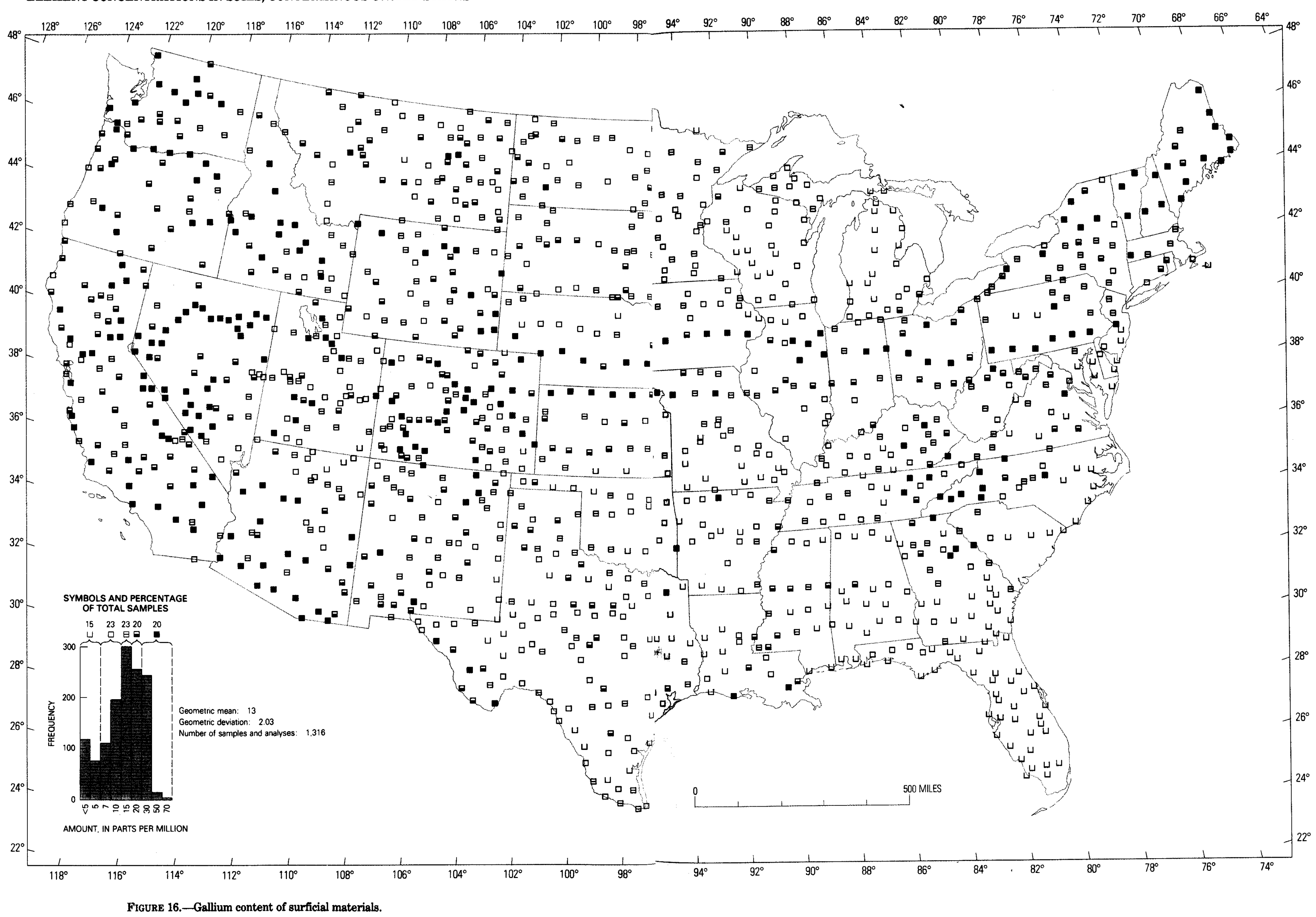




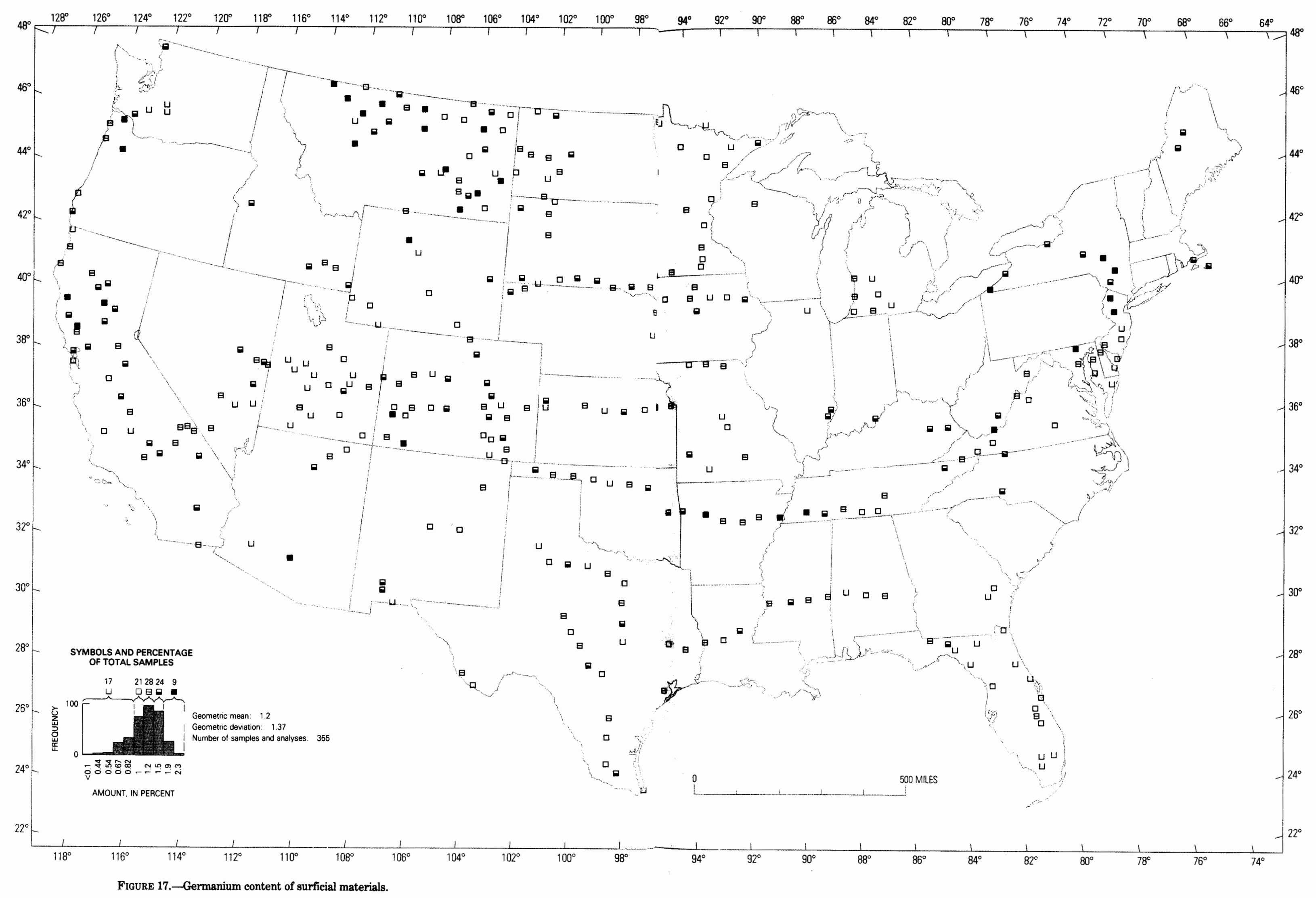




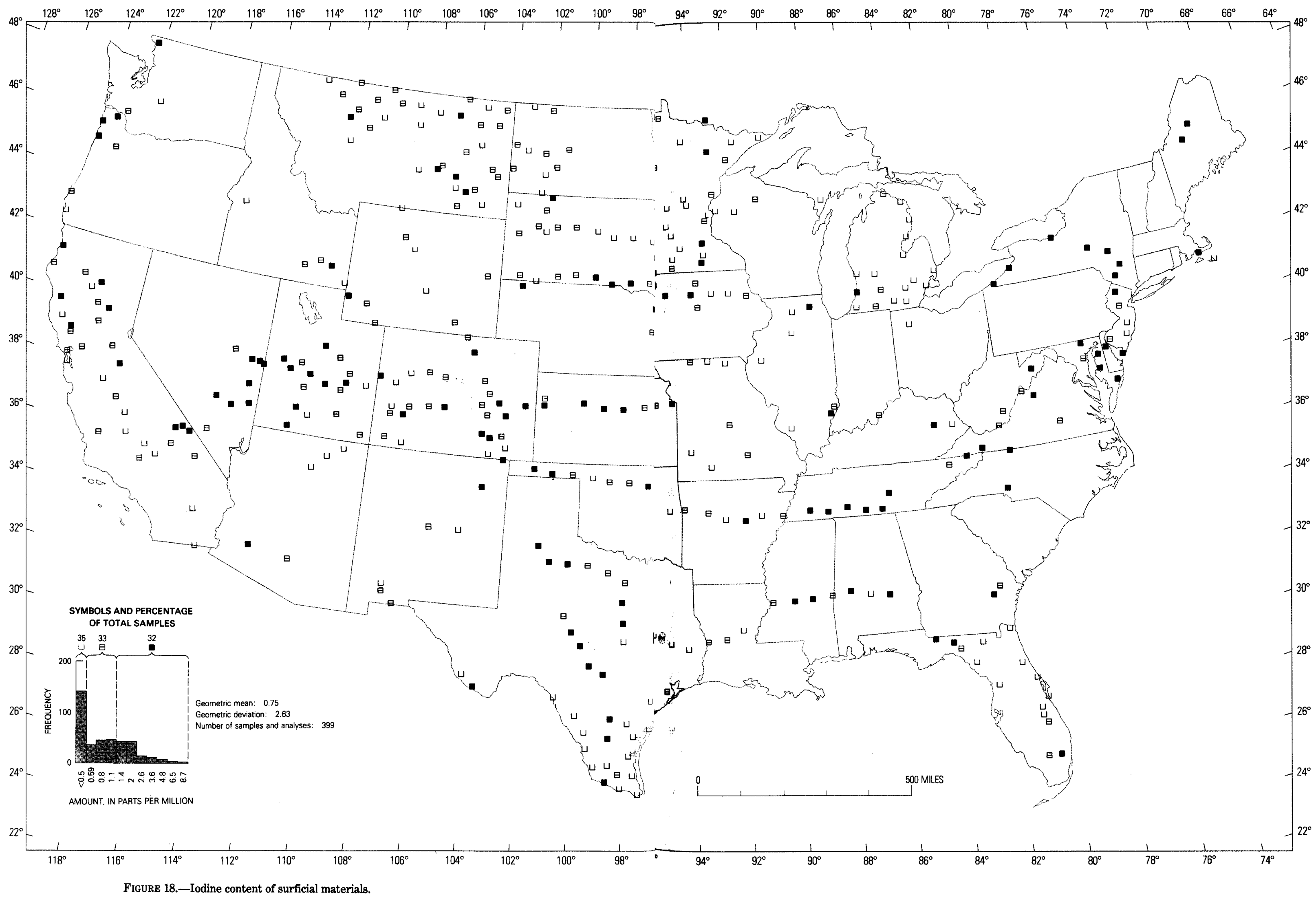




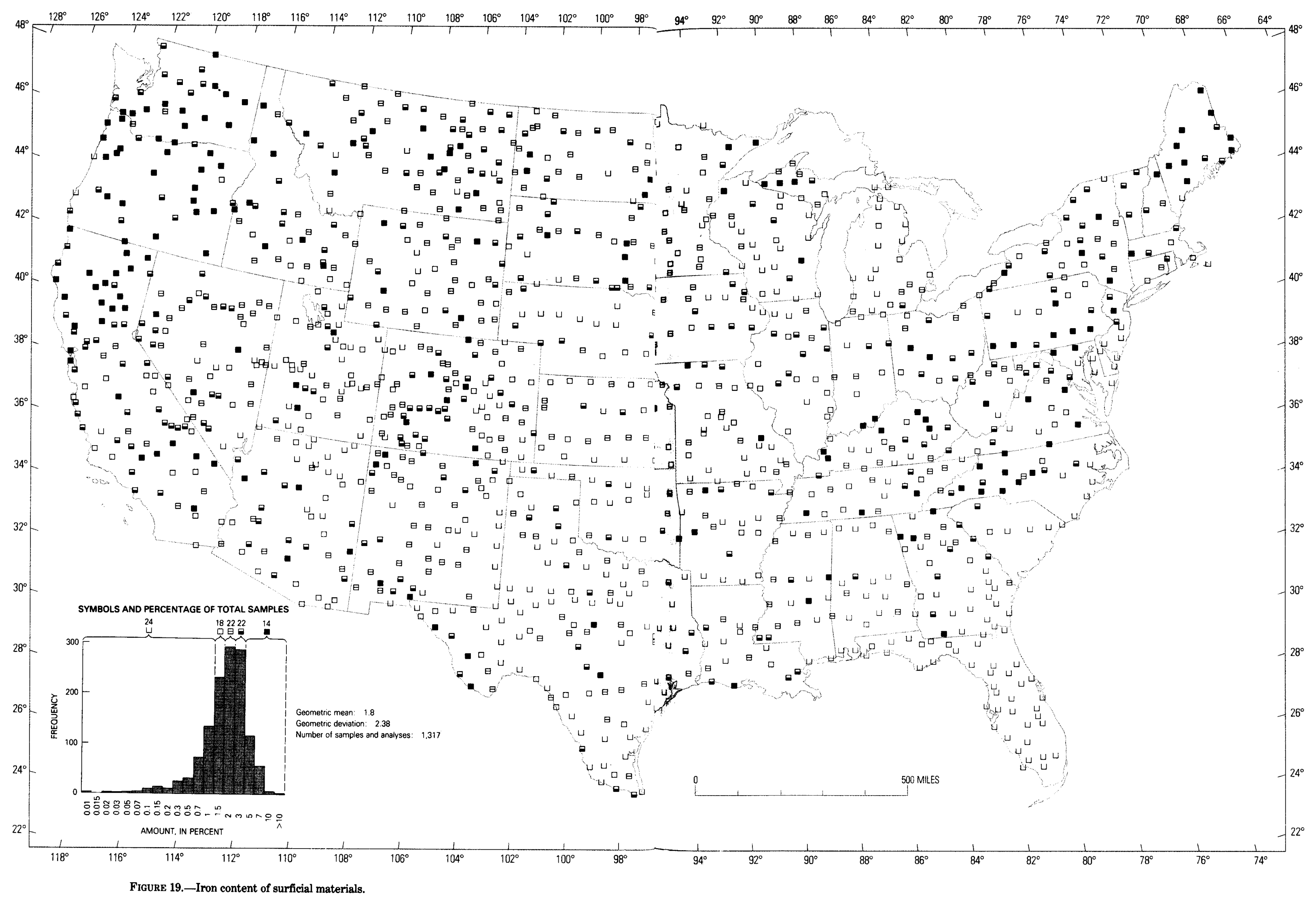




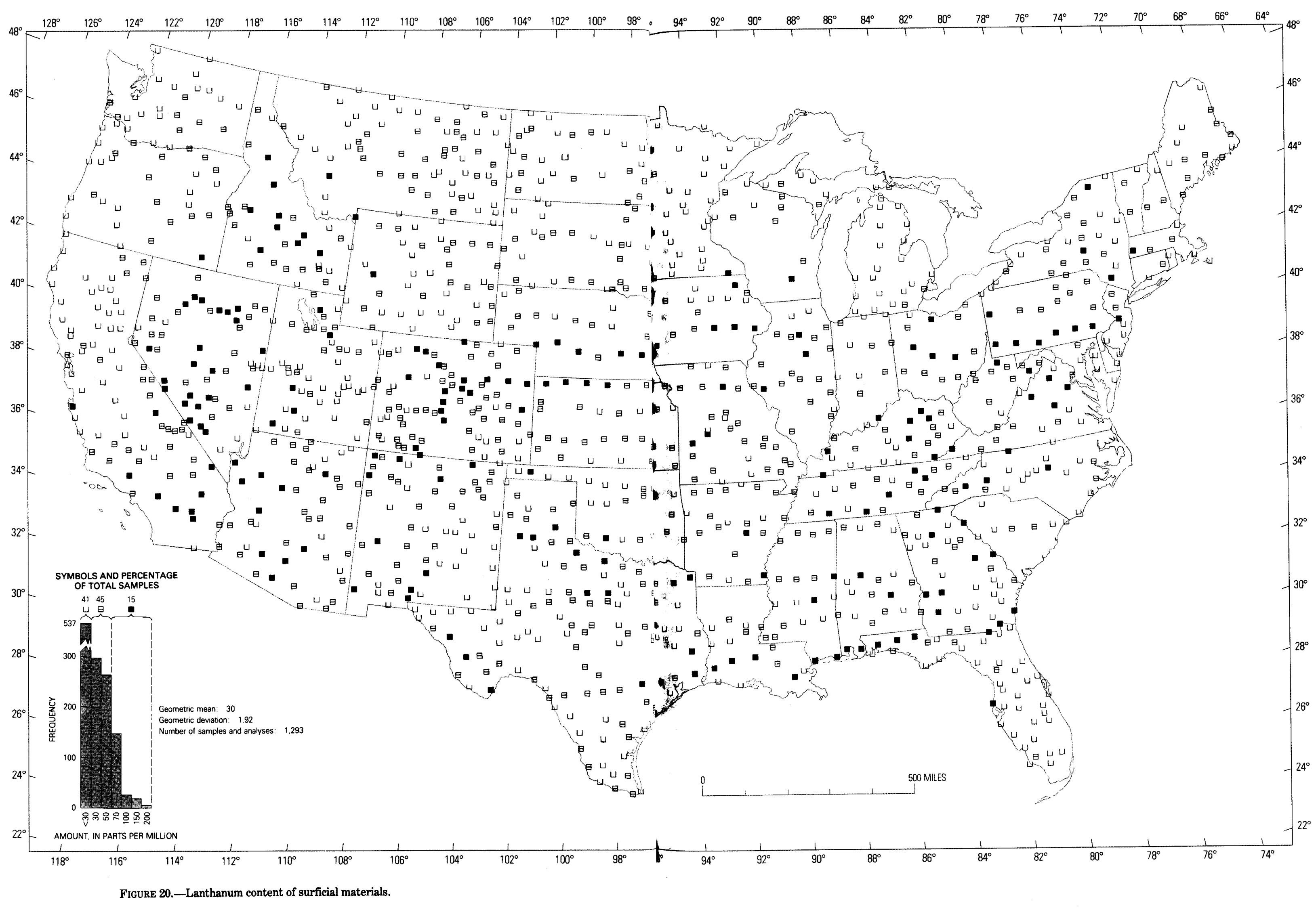




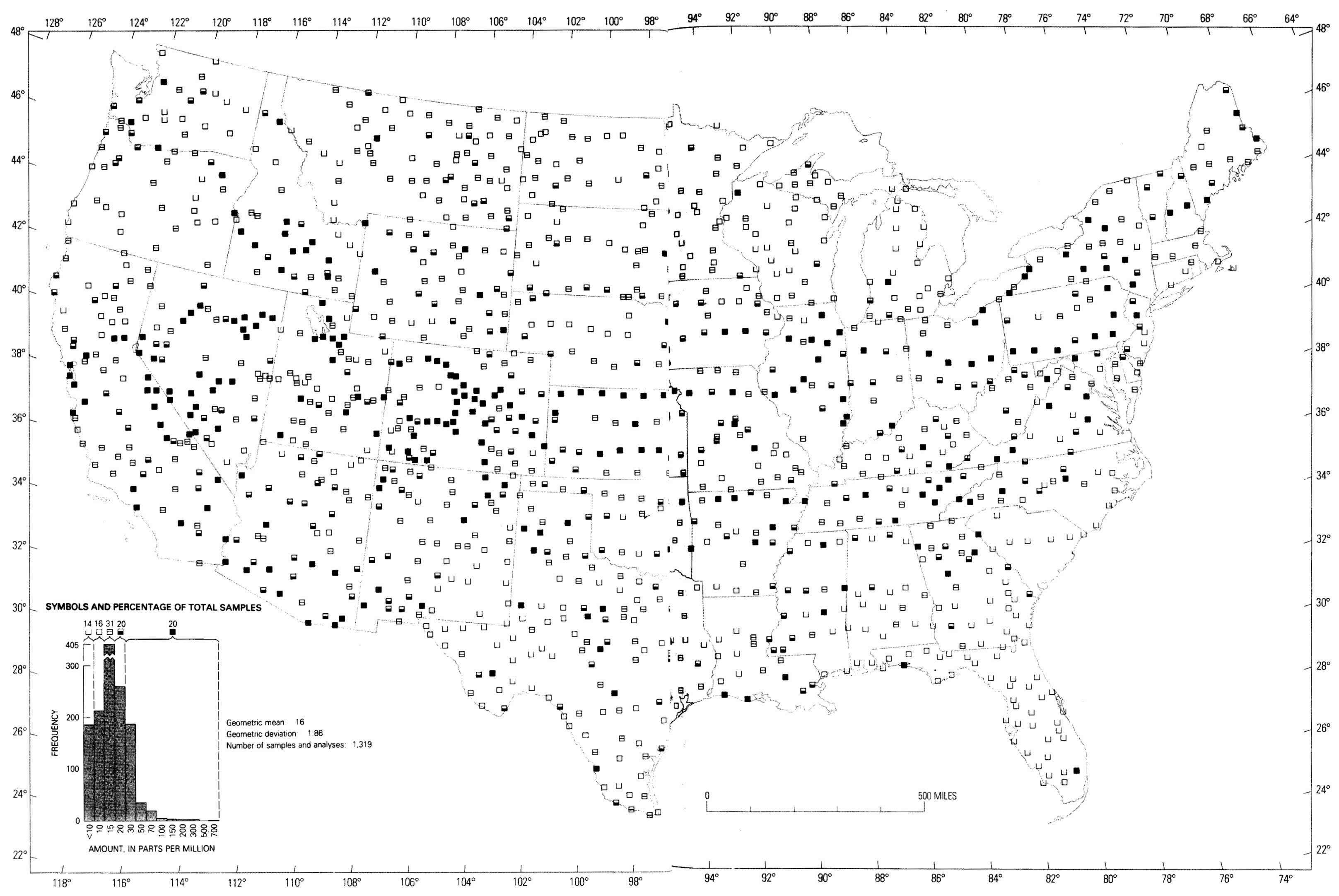

FIGURE 21.-Lead content of surficial materials. 


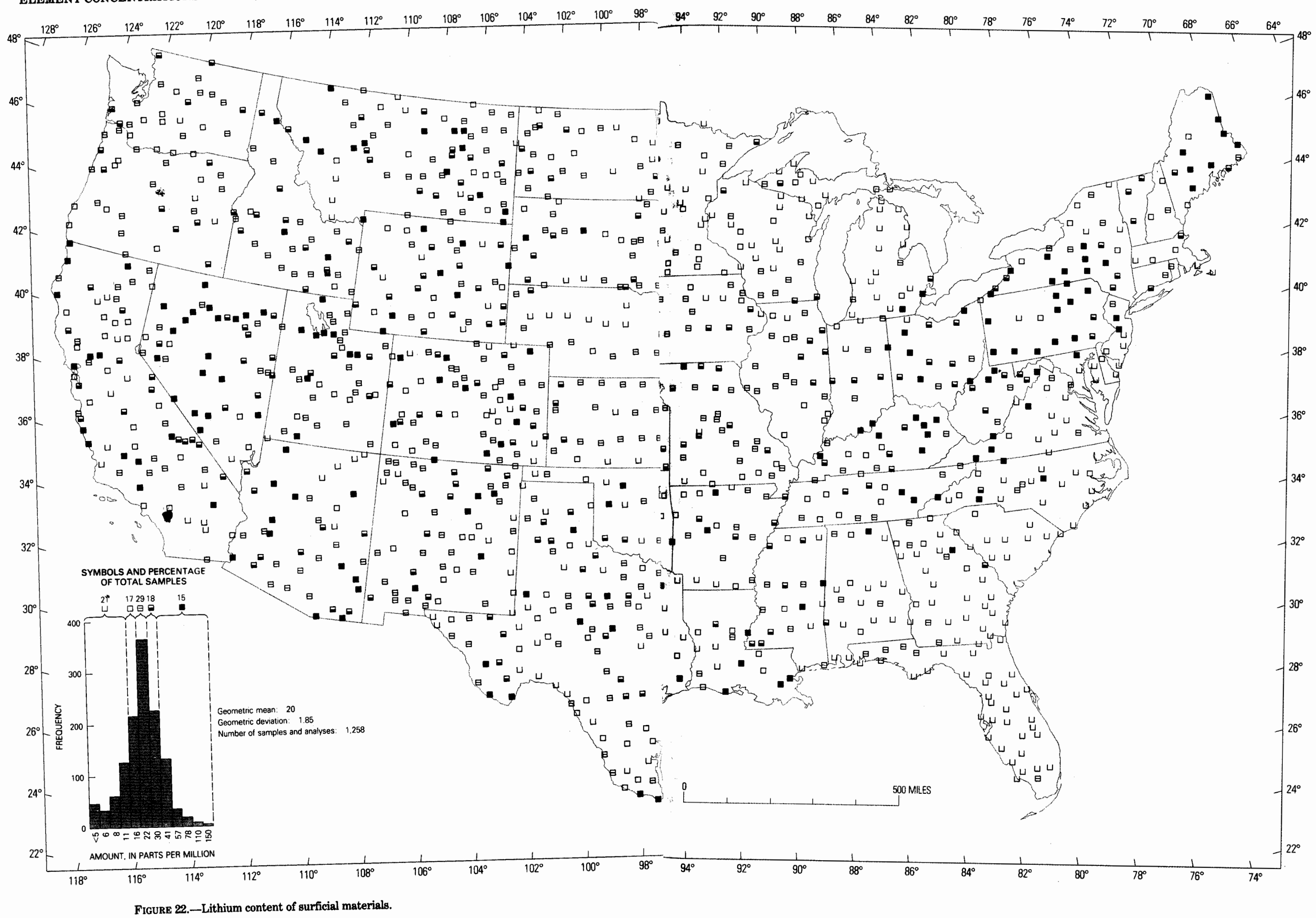




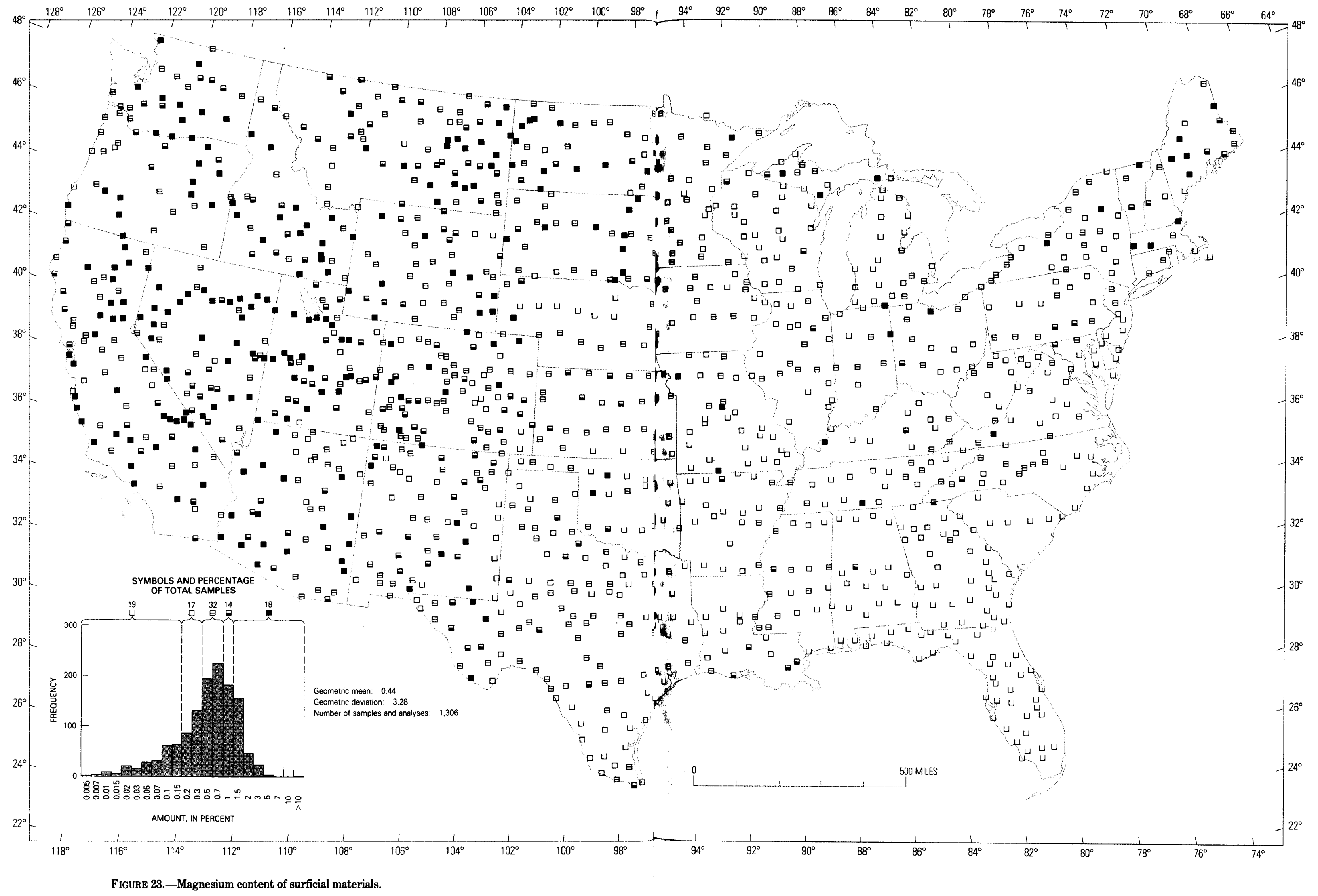




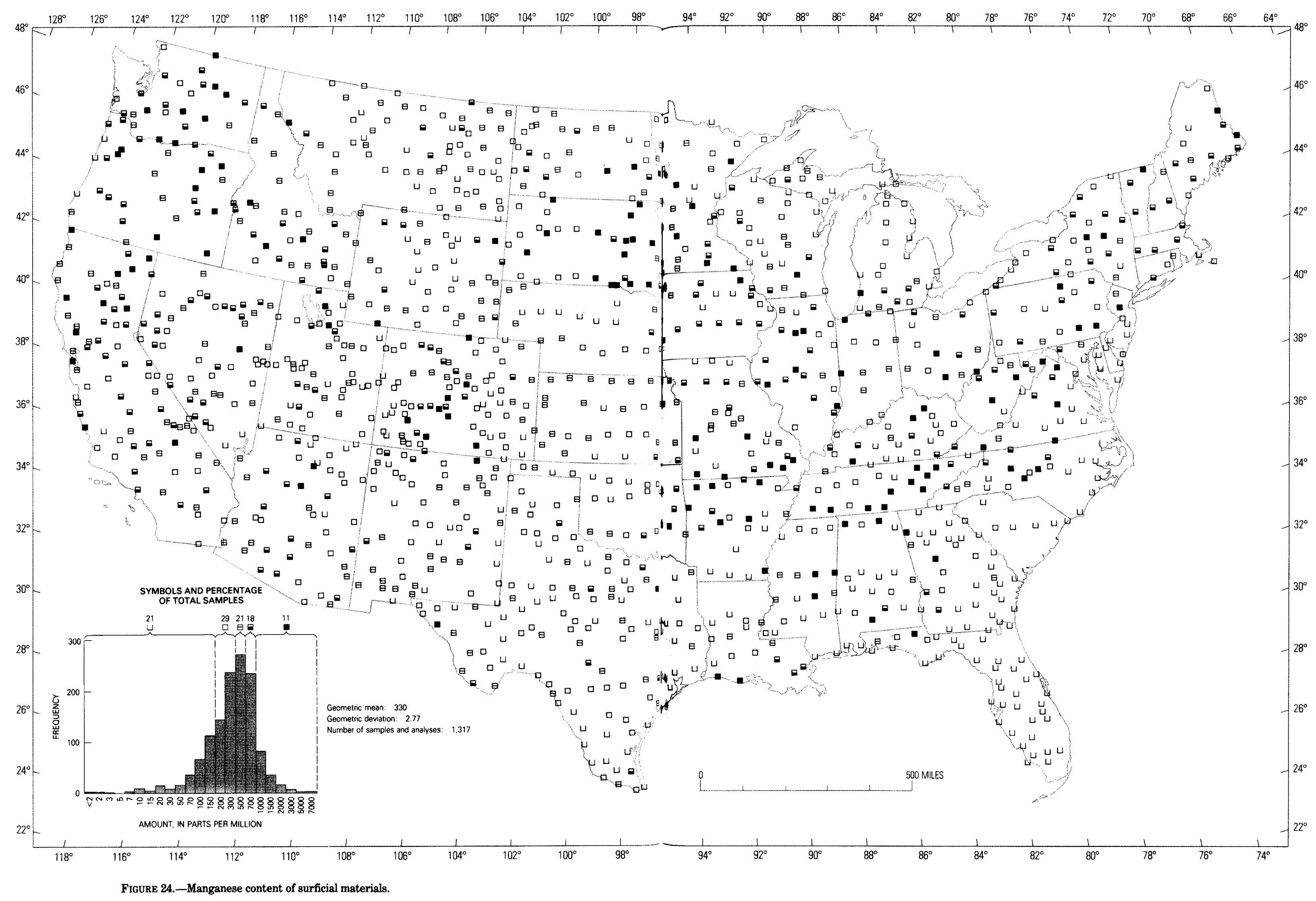




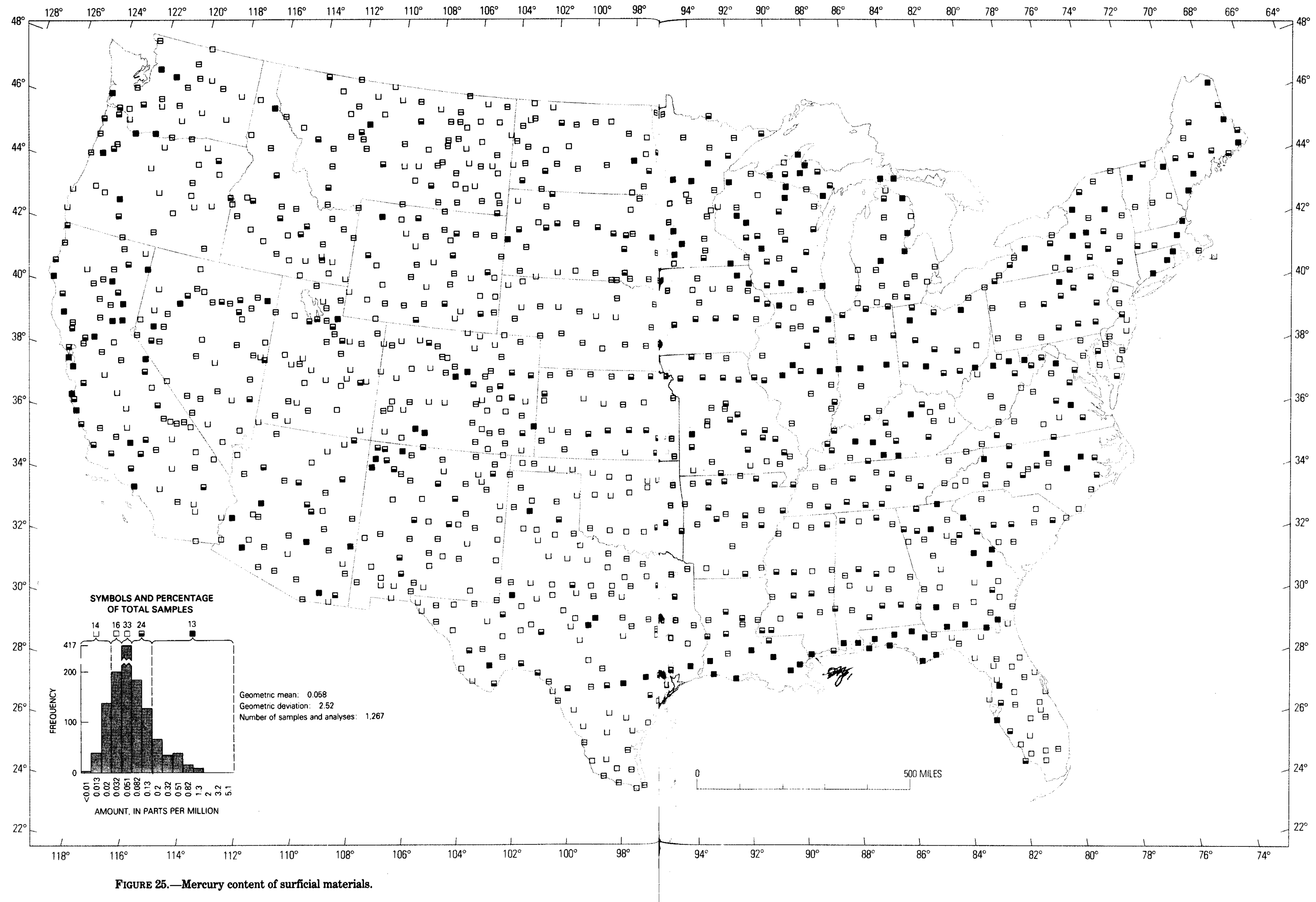




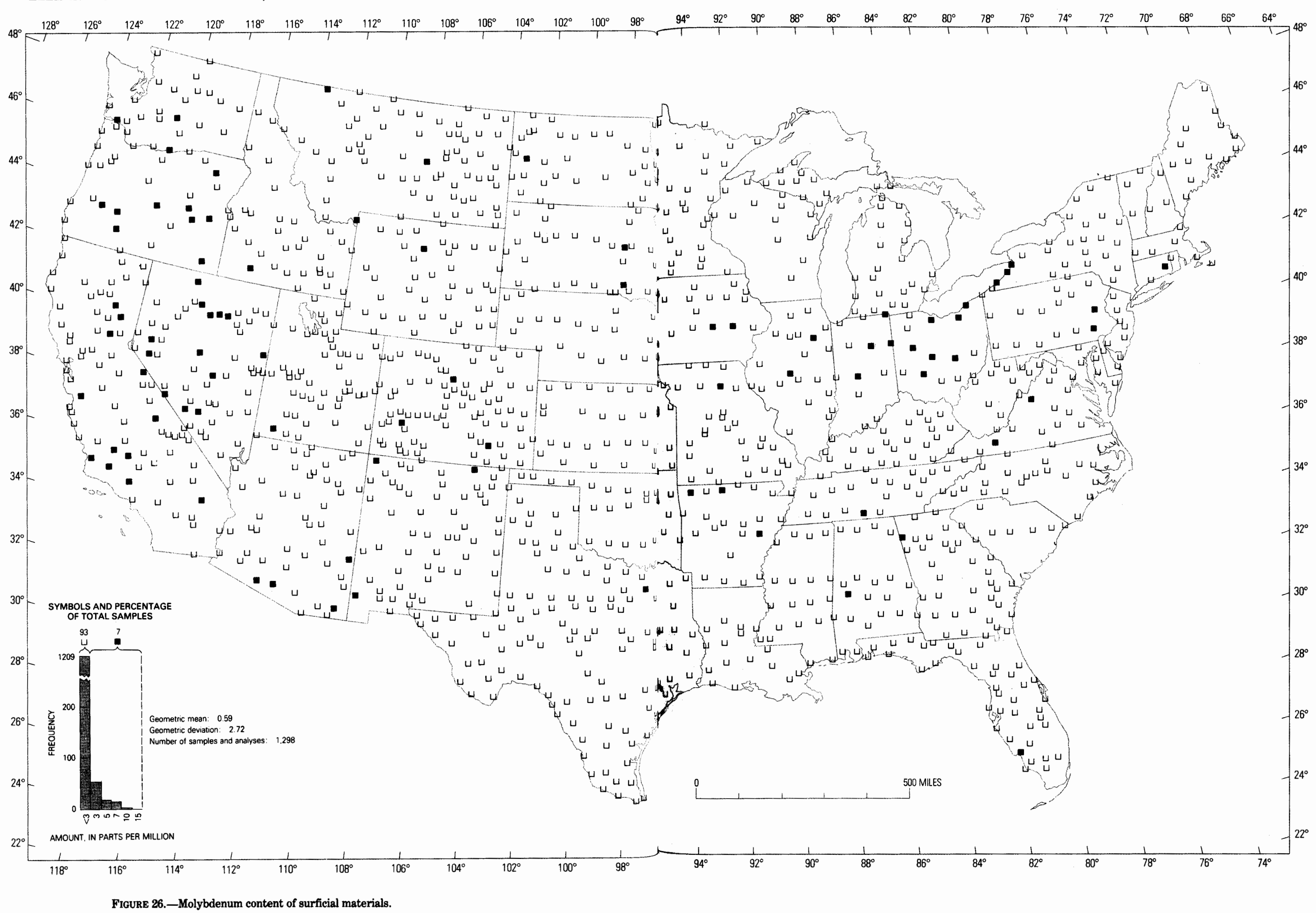




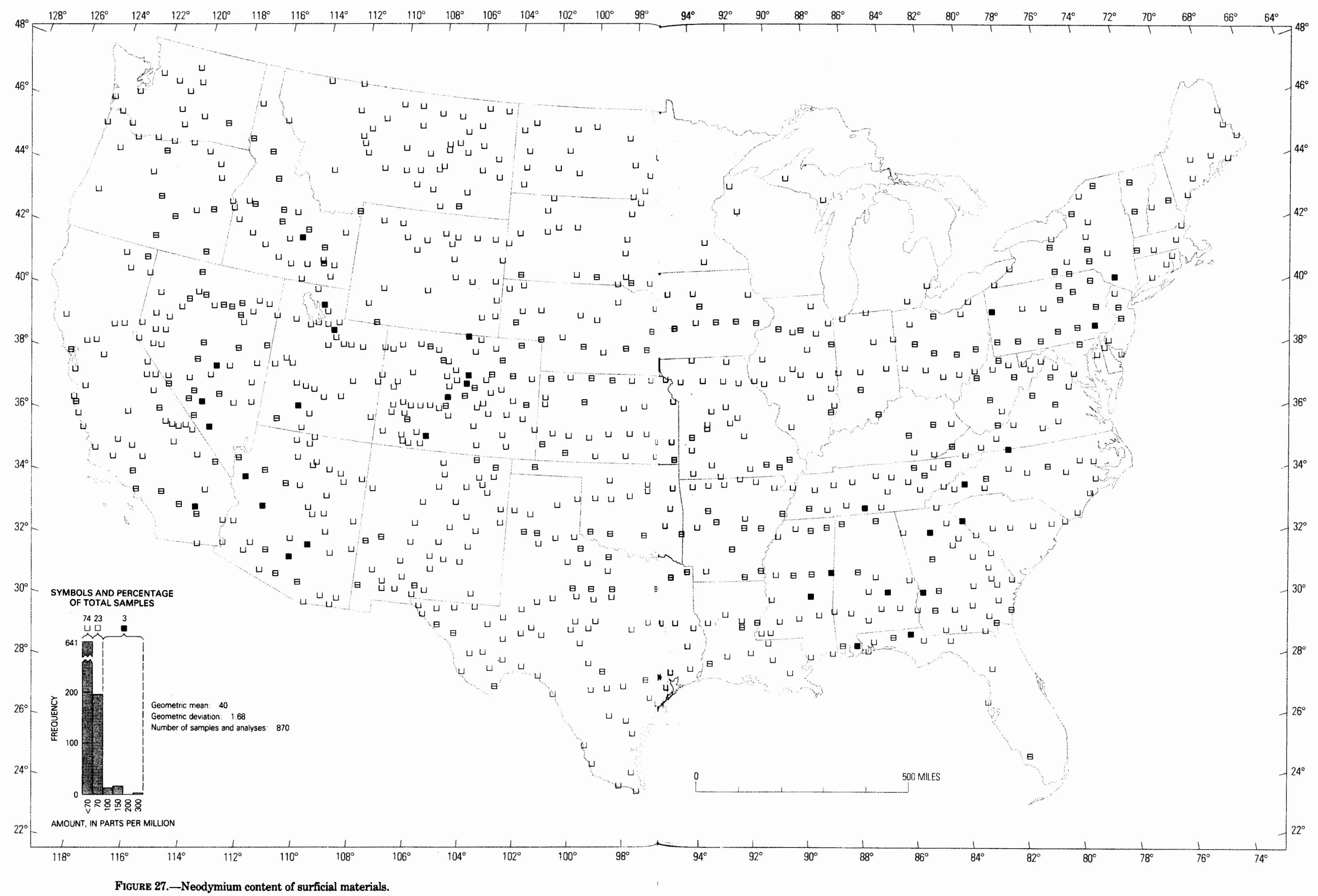




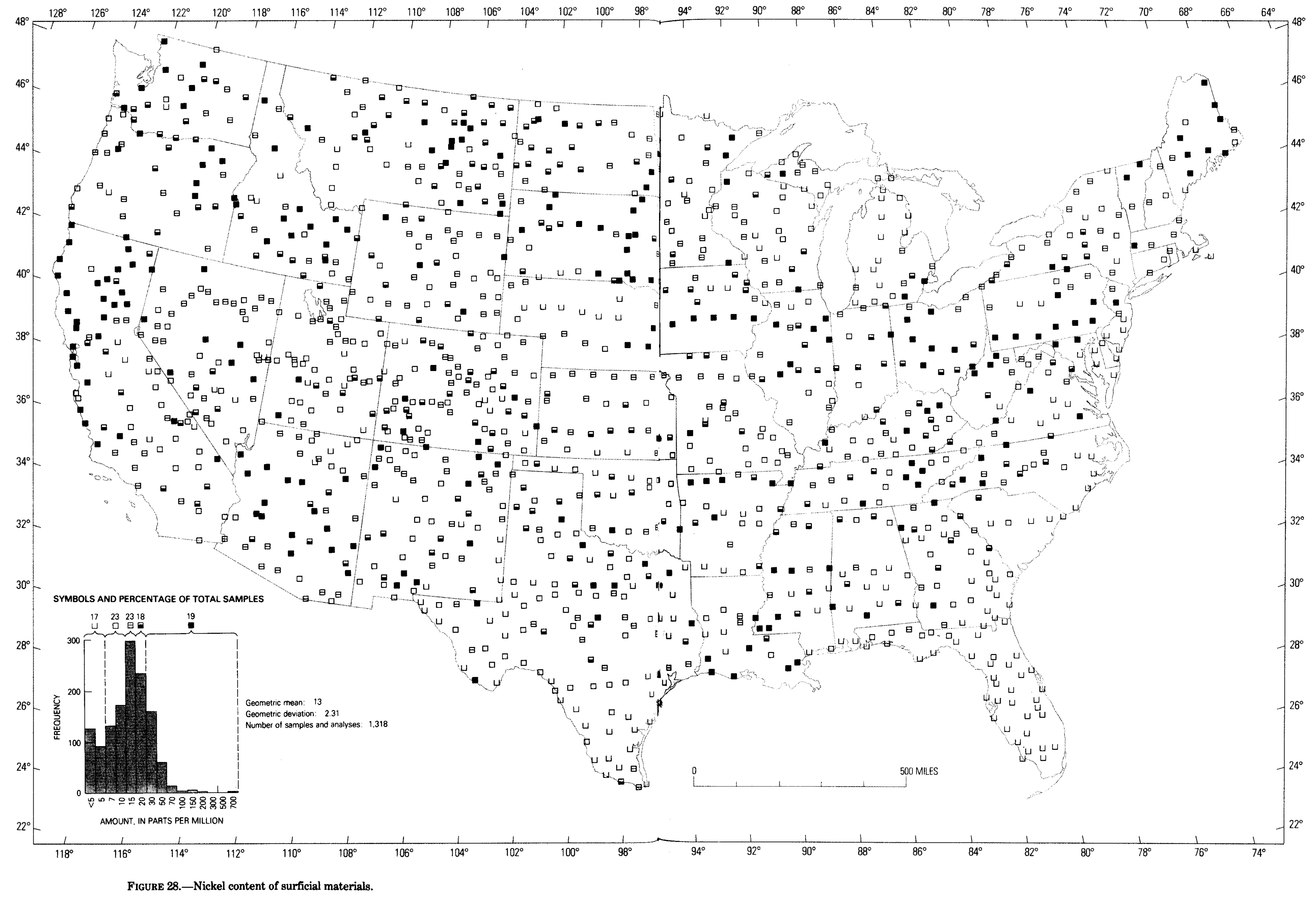




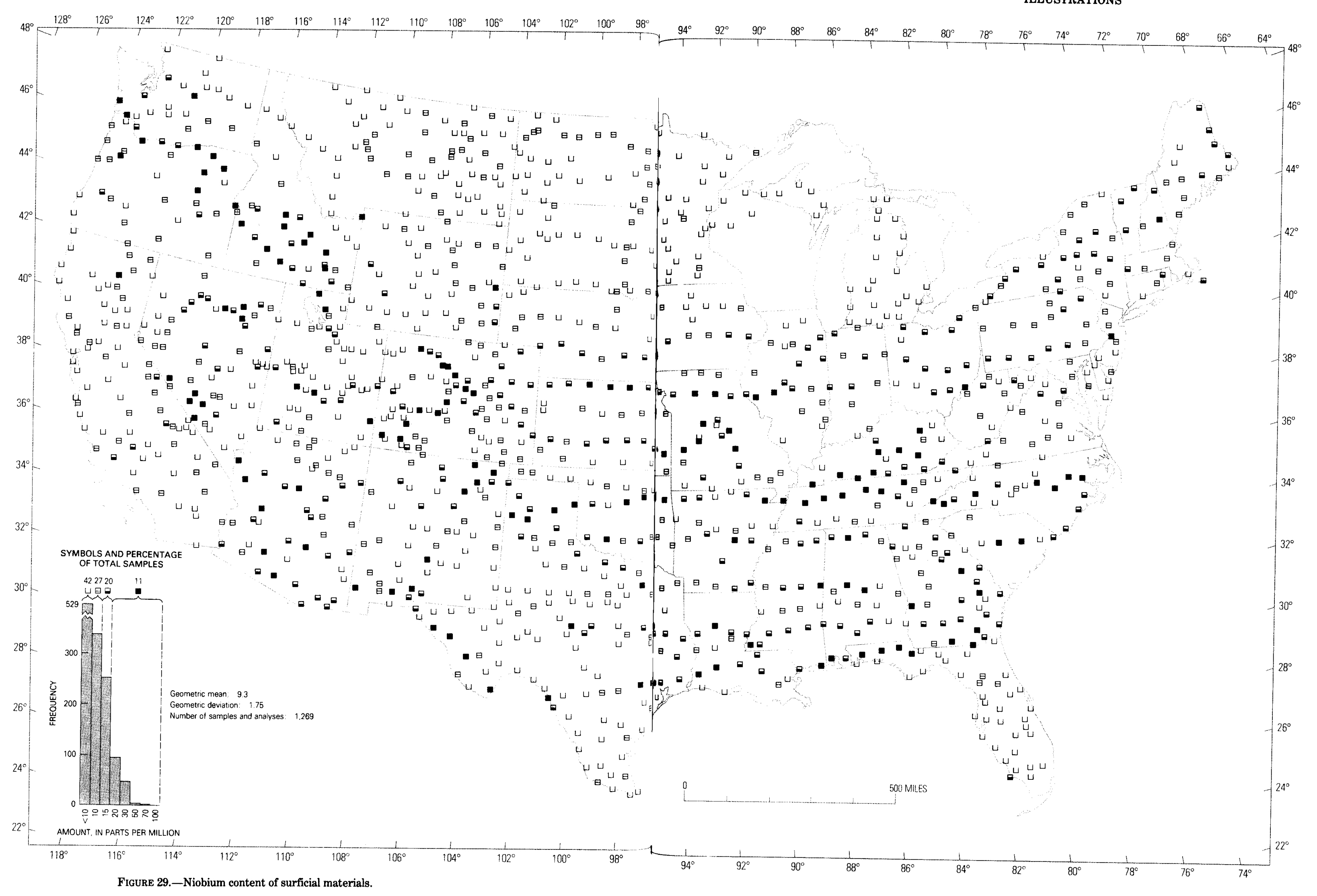




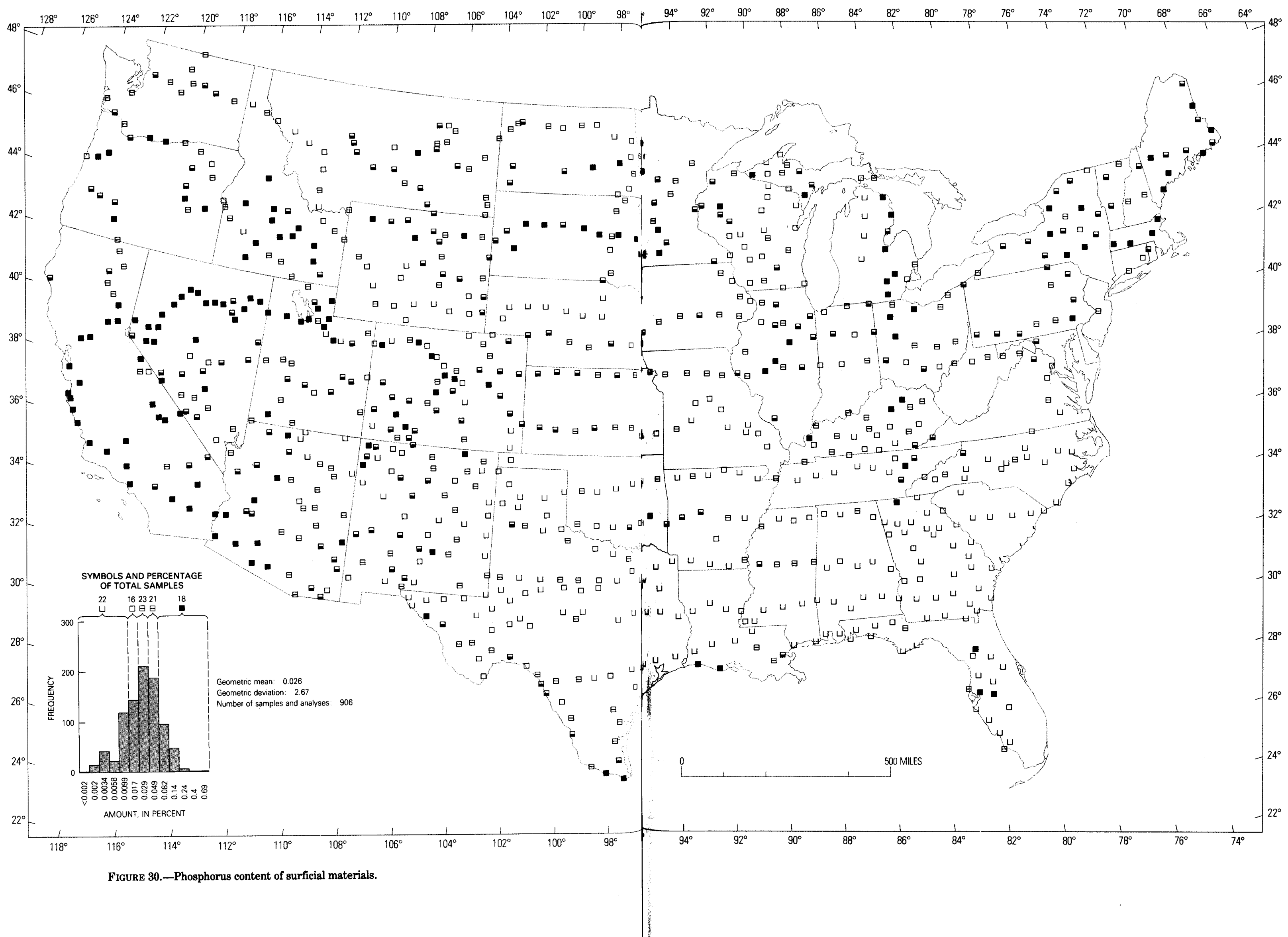




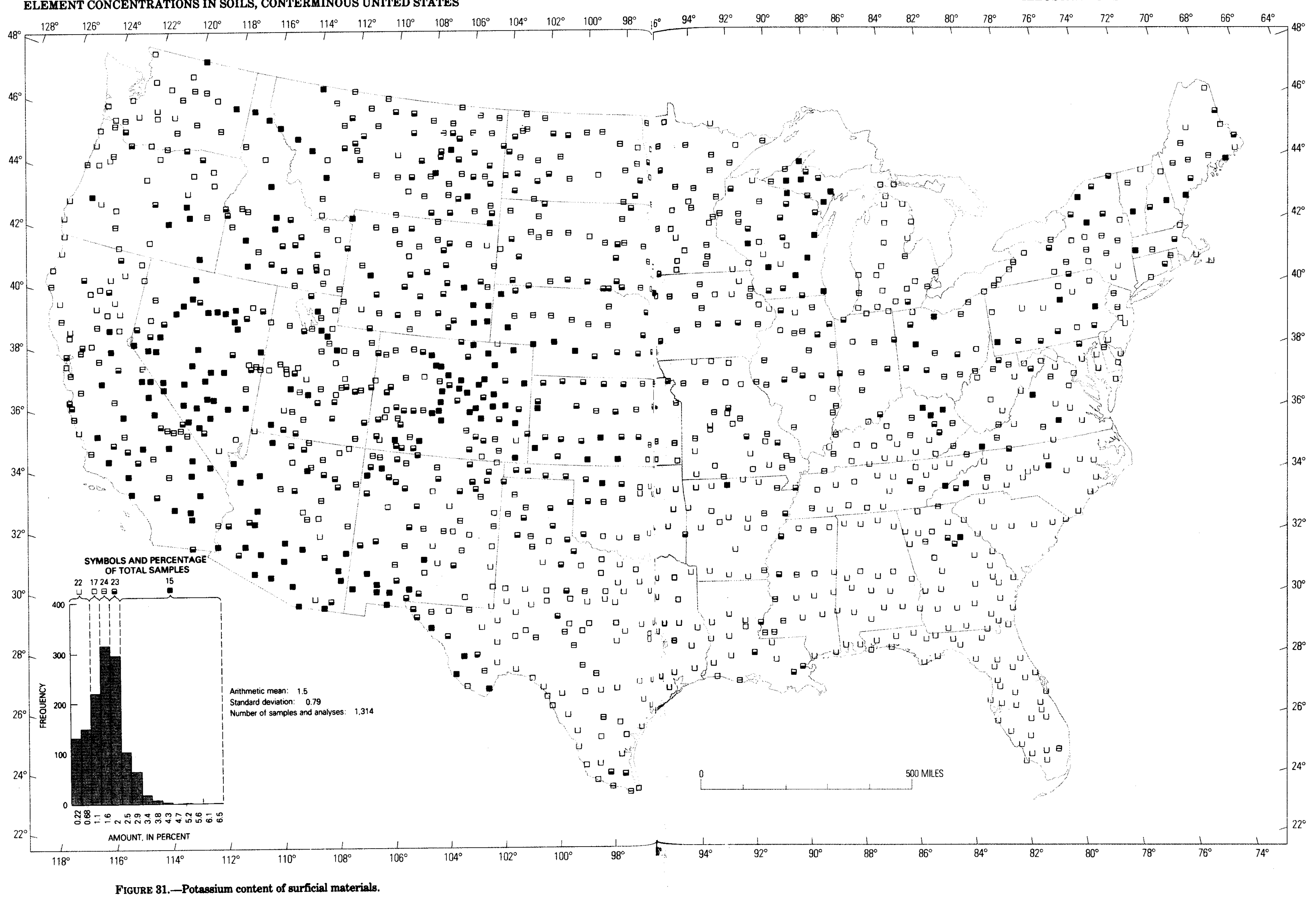




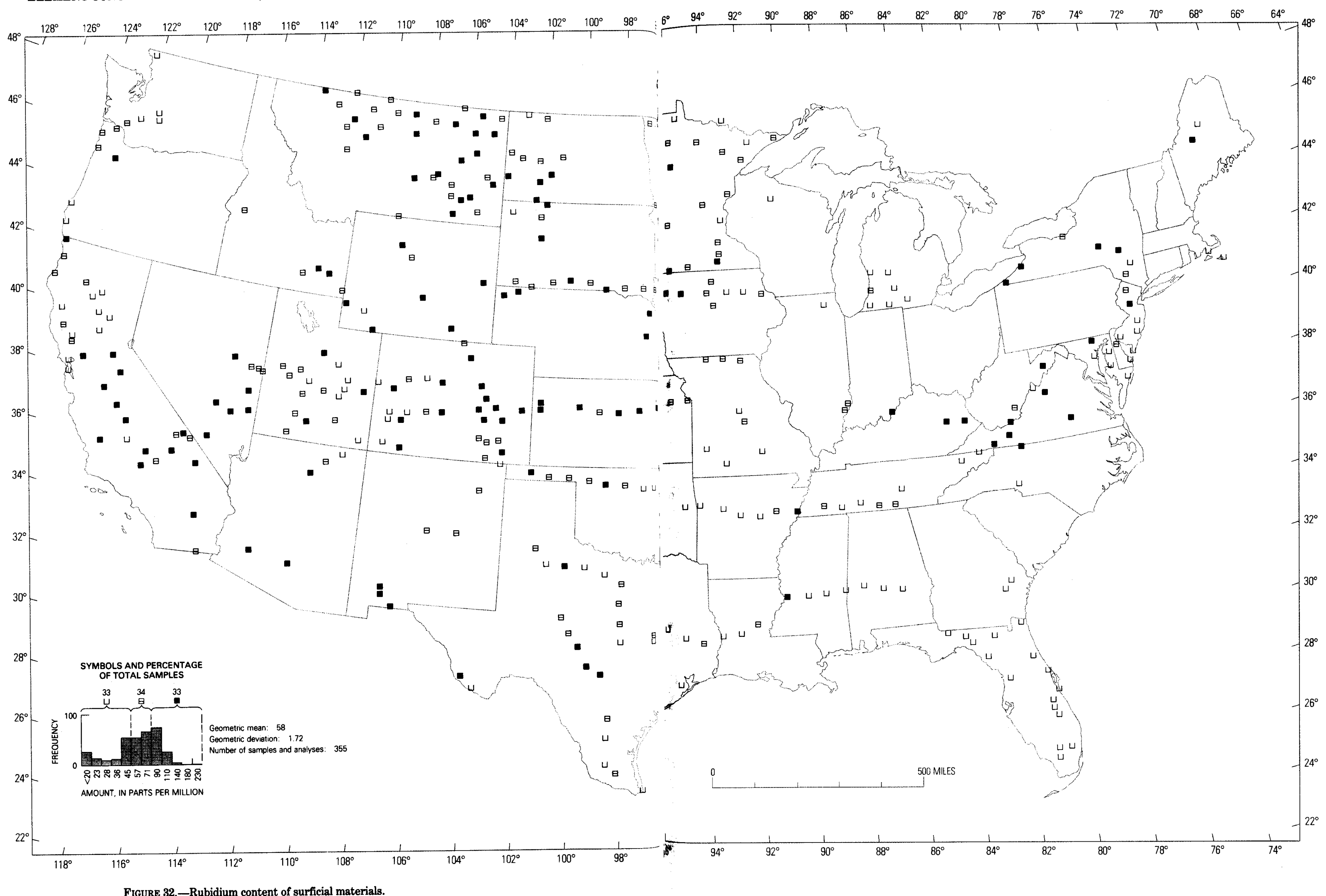




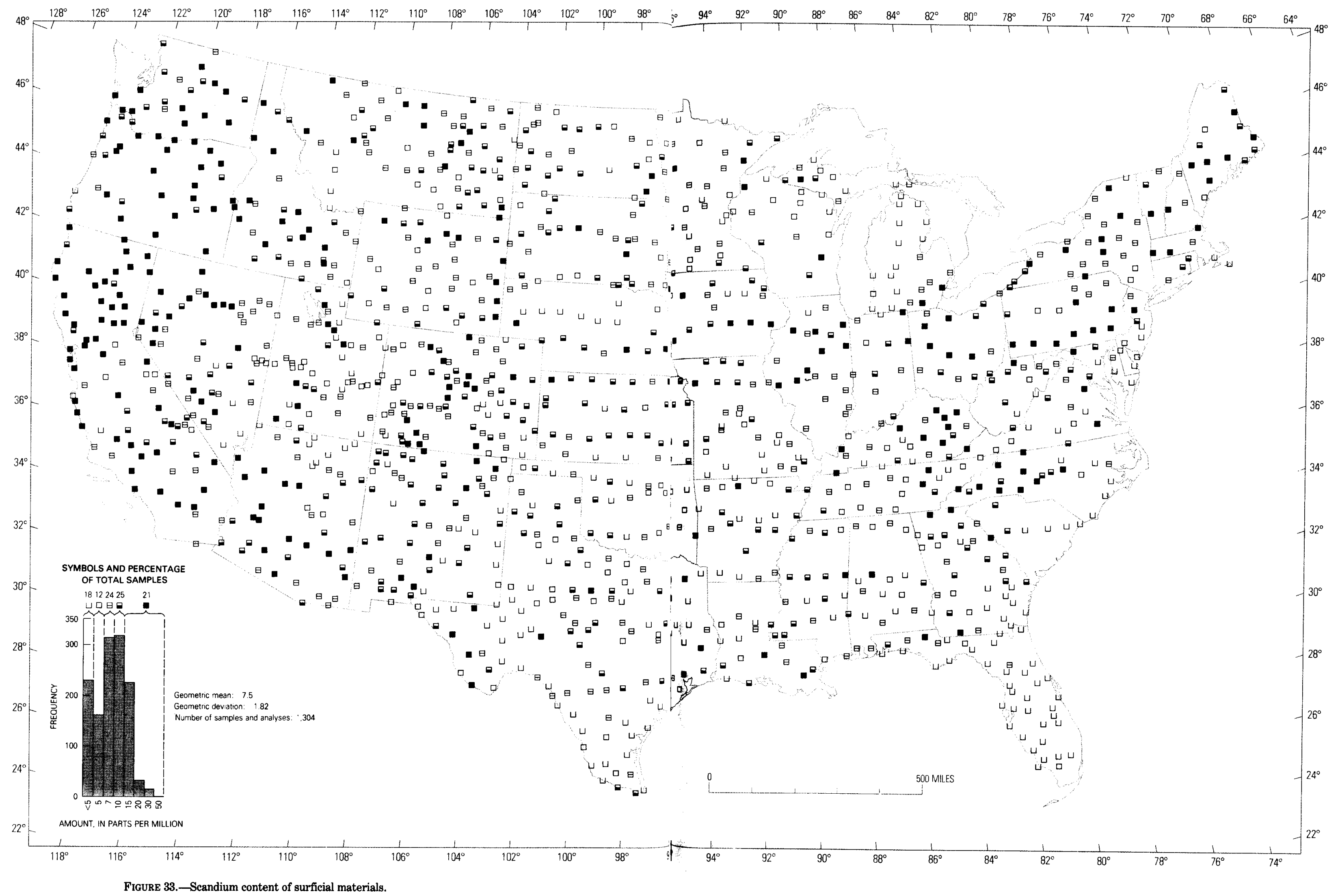




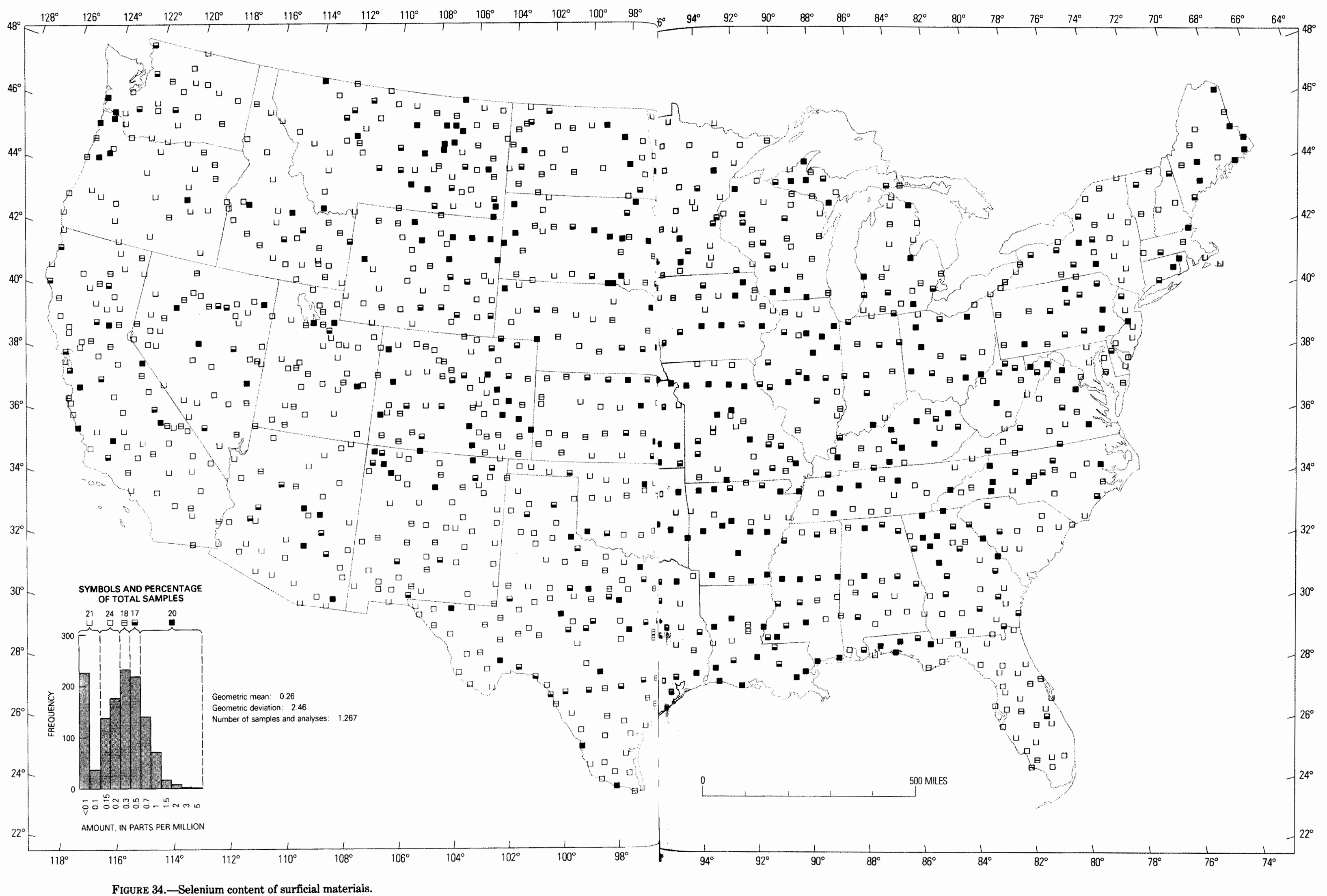




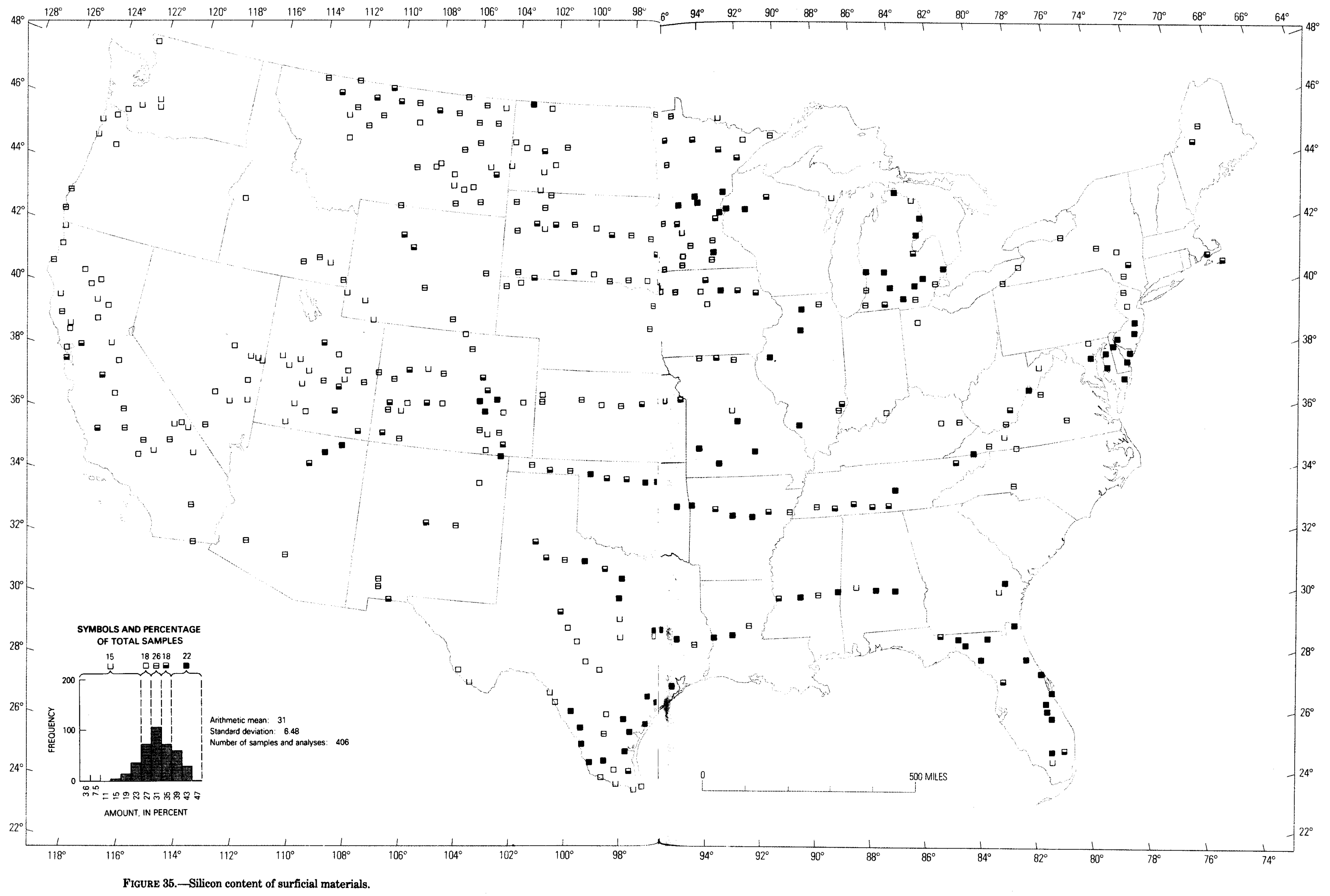




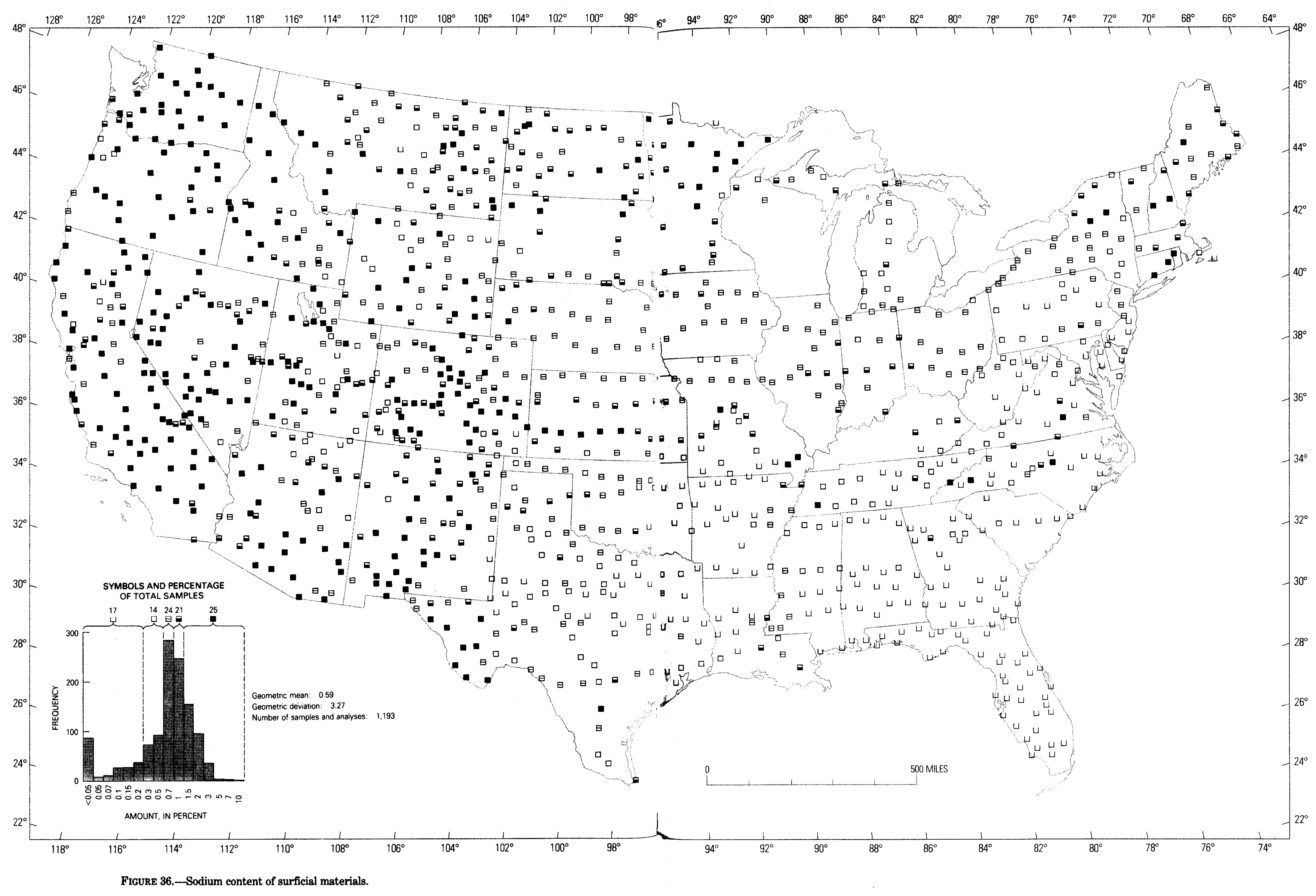




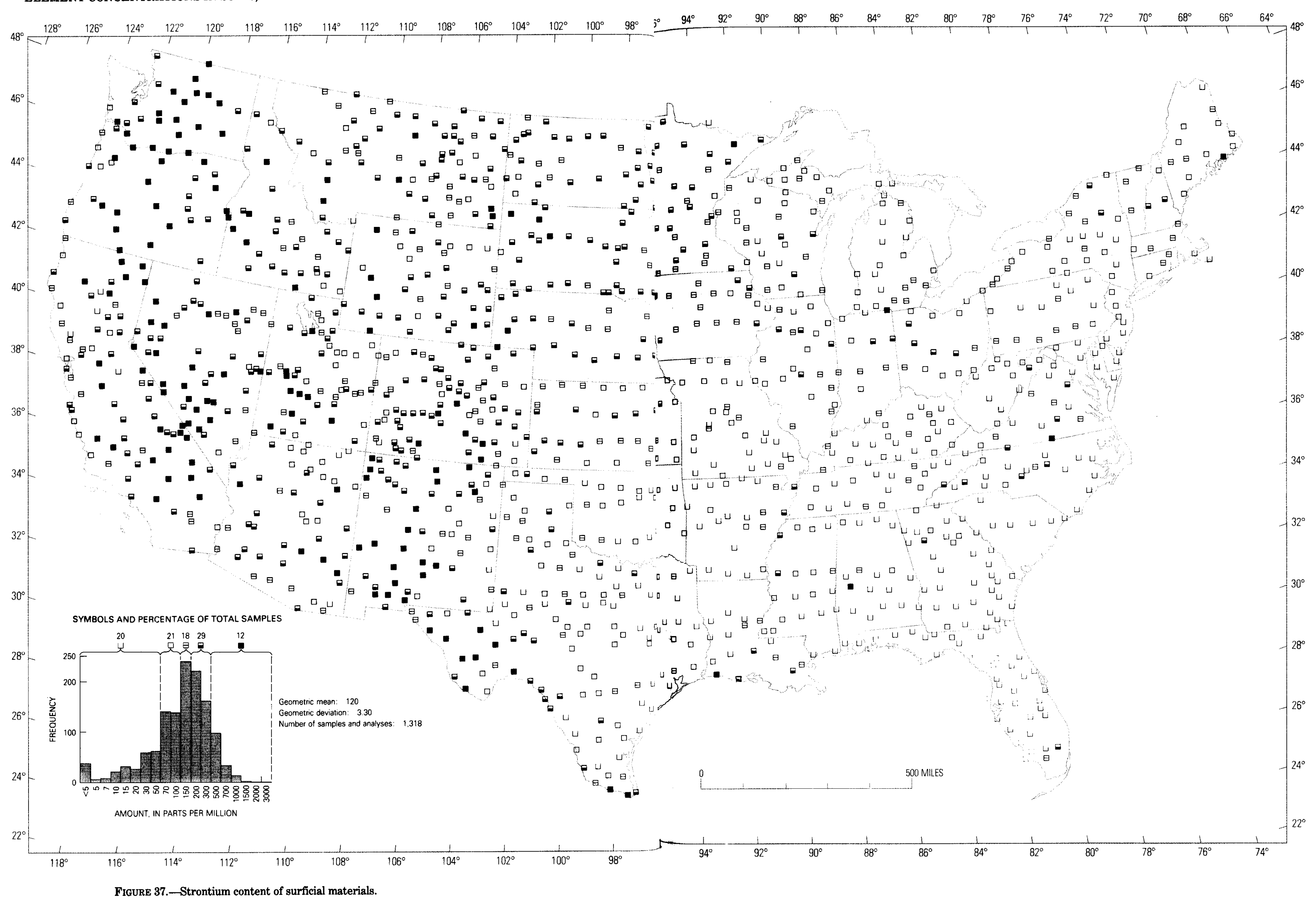


86

ELEMENT CONCENTRATIONS IN SOILS, CONTERMINOUS UNITED STATES

ILLUSTRATIONS

87

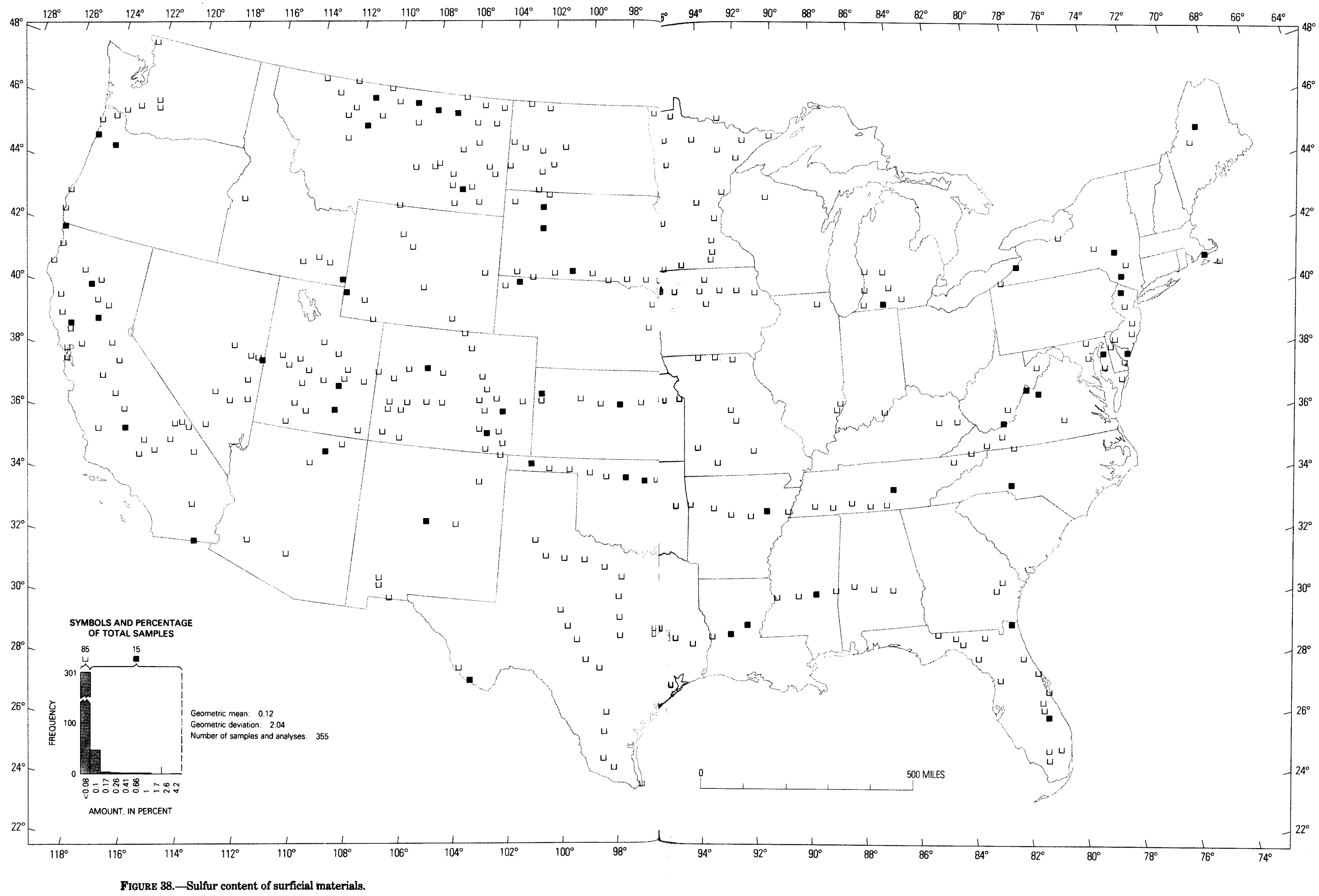


88

ELEMENT CONCENTRATIONS IN SOILS, CONTERMINOUS UNITED STATES

ILLUSTRATIONS

89

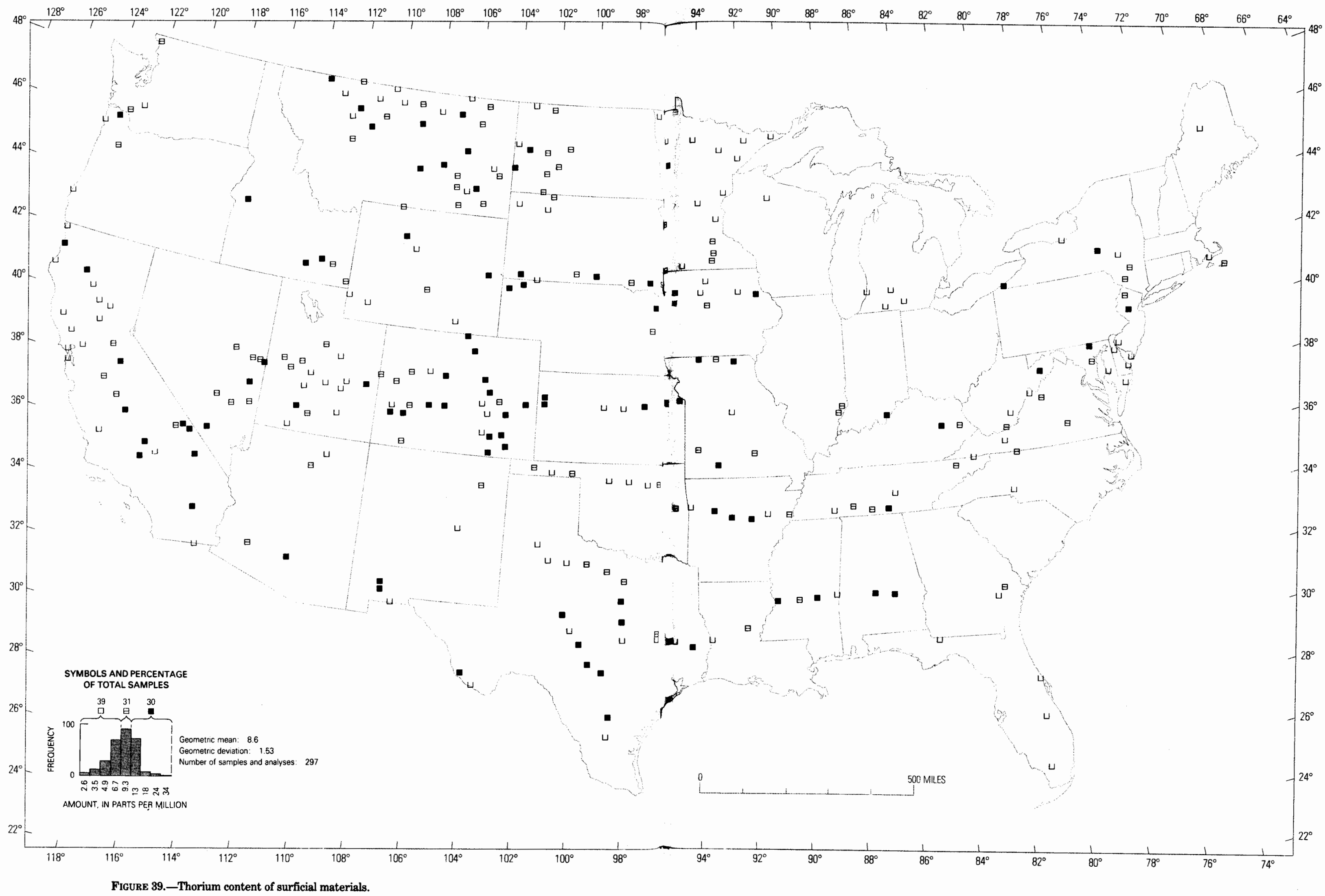





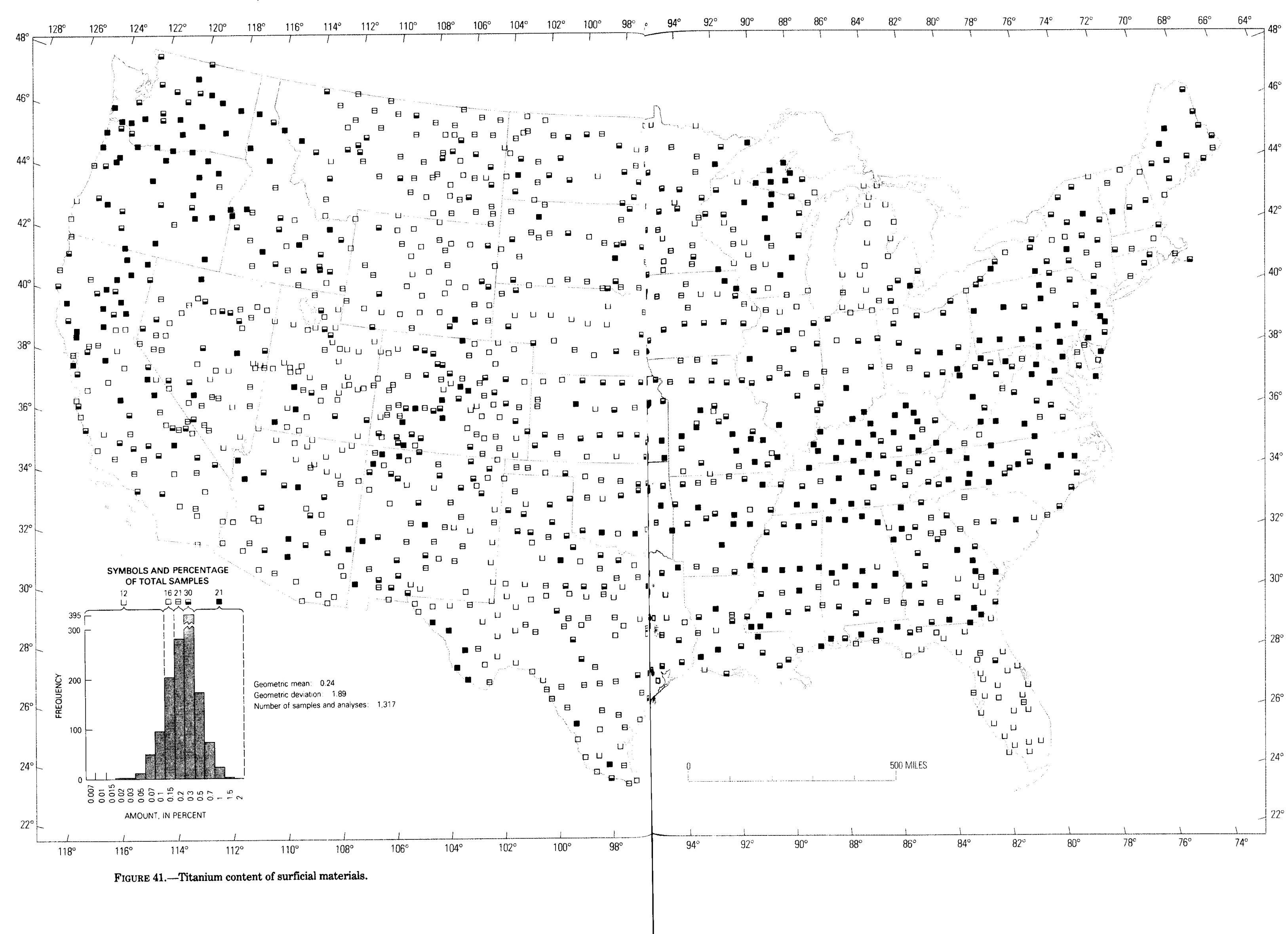




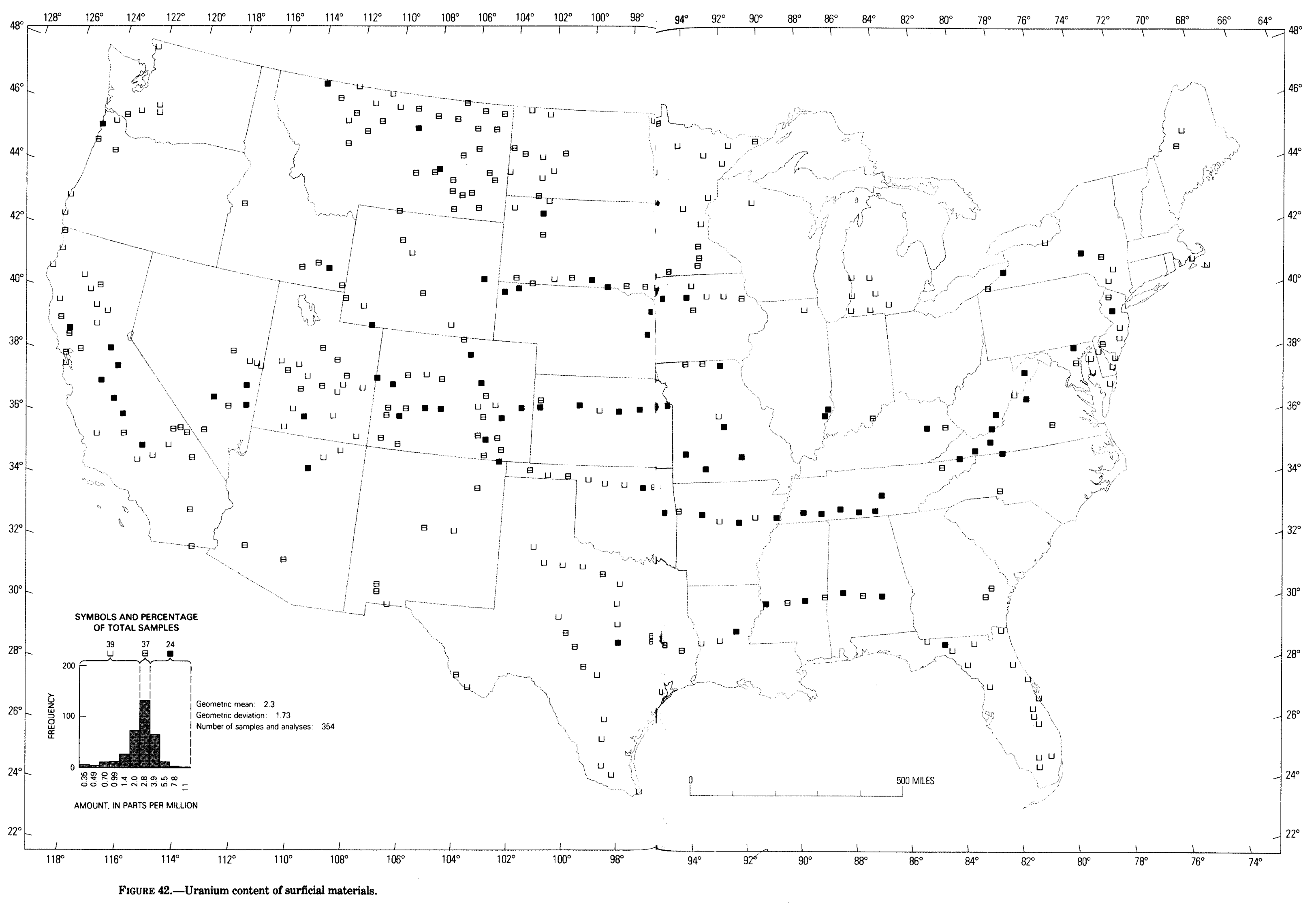




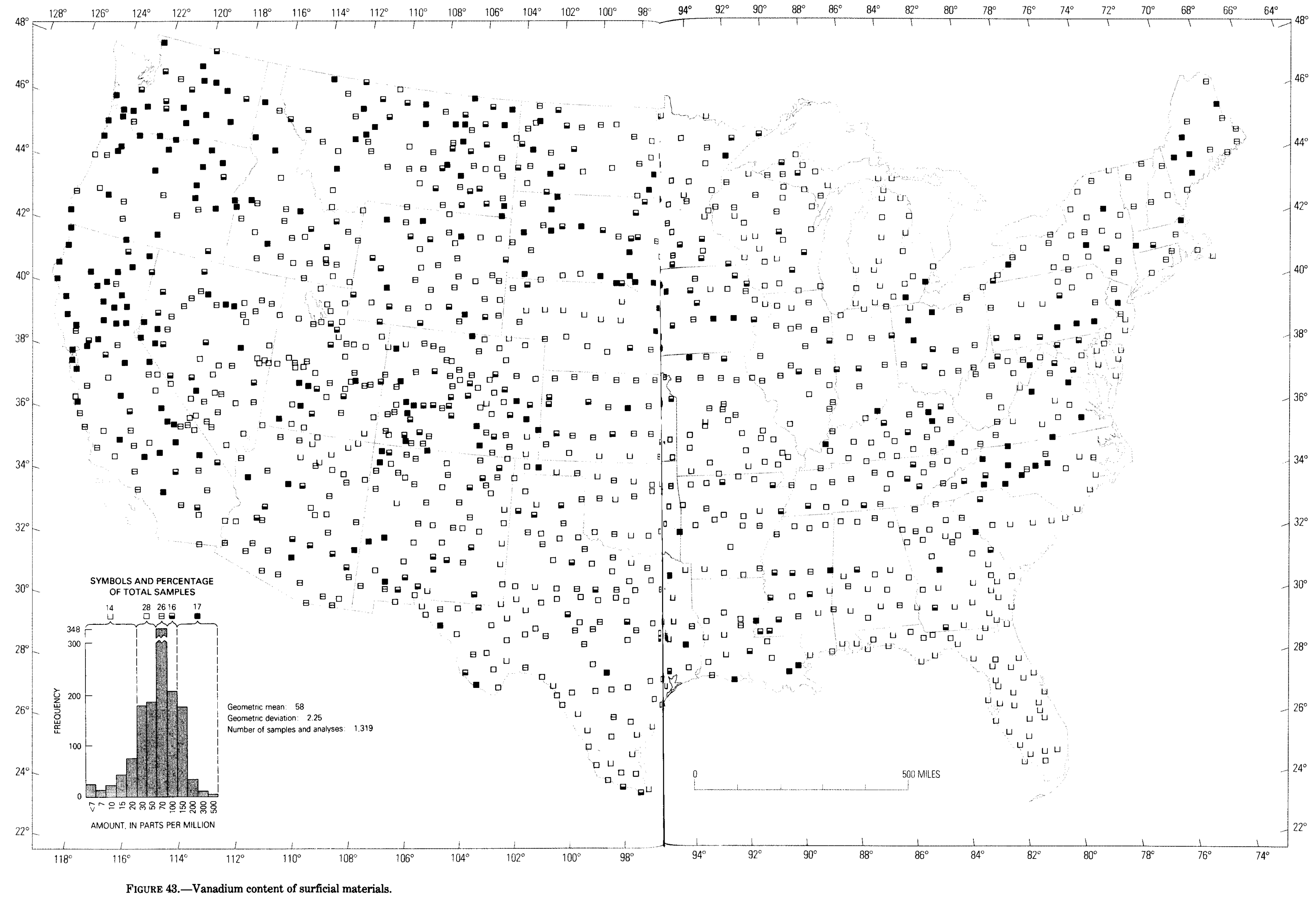




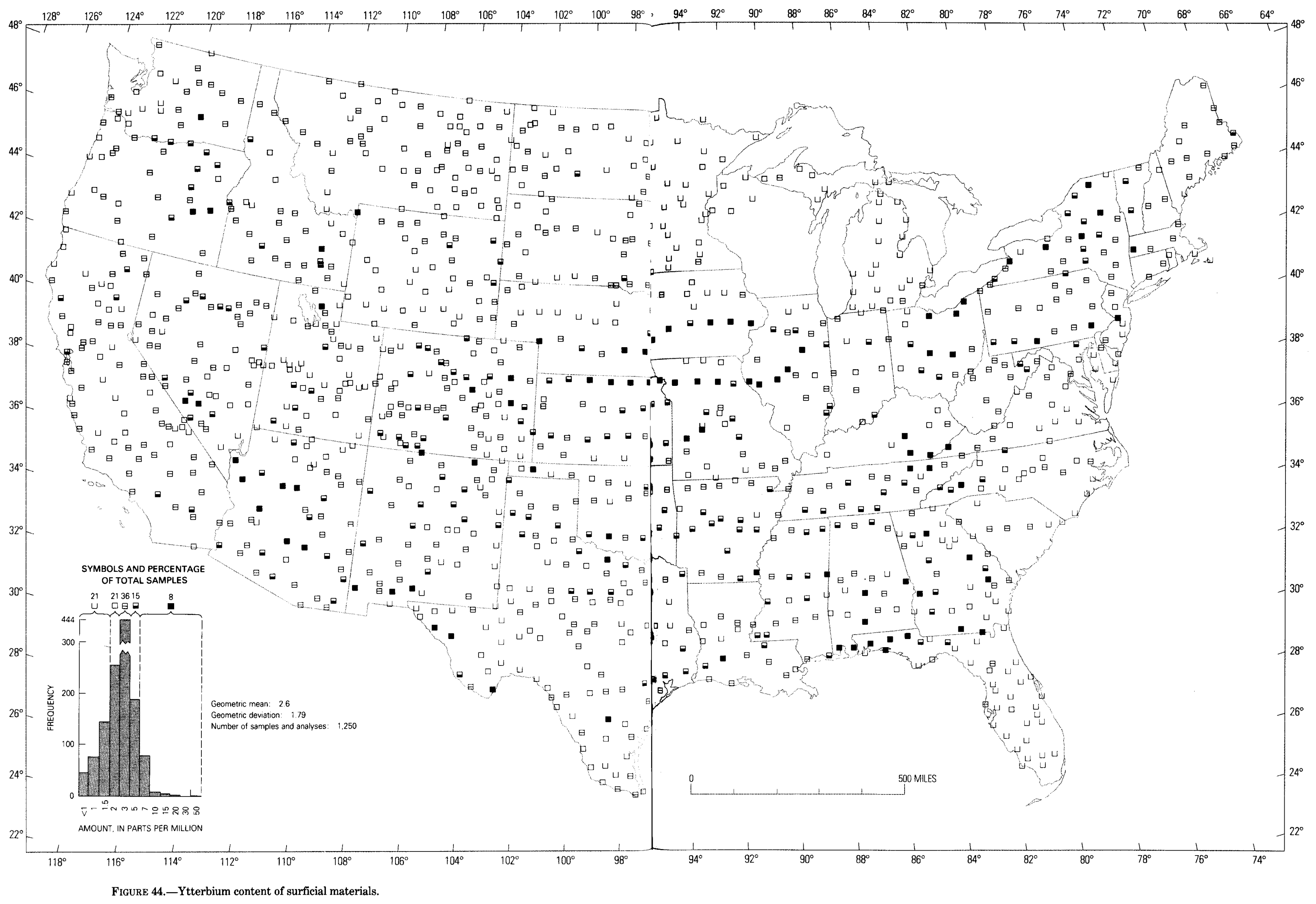




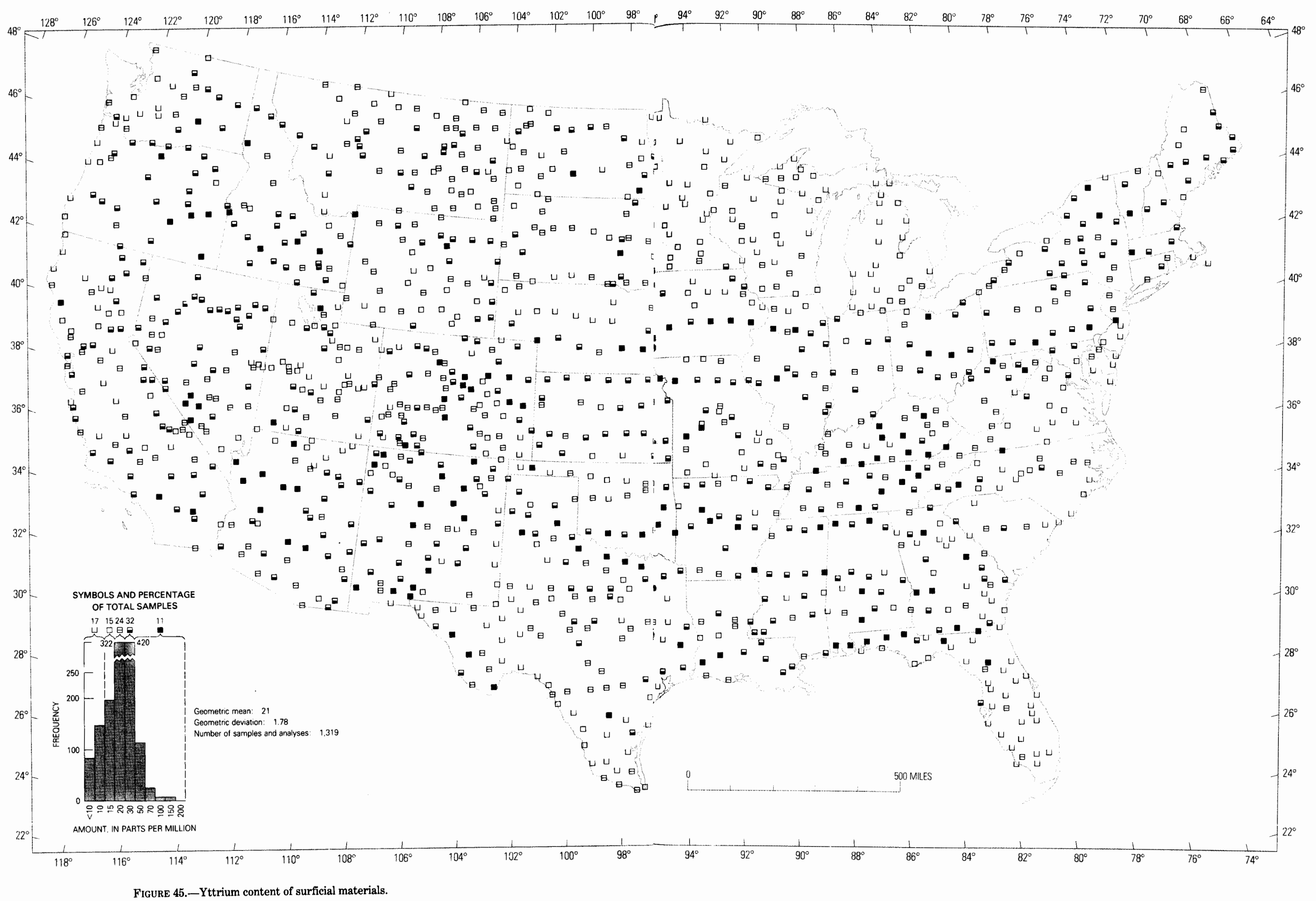




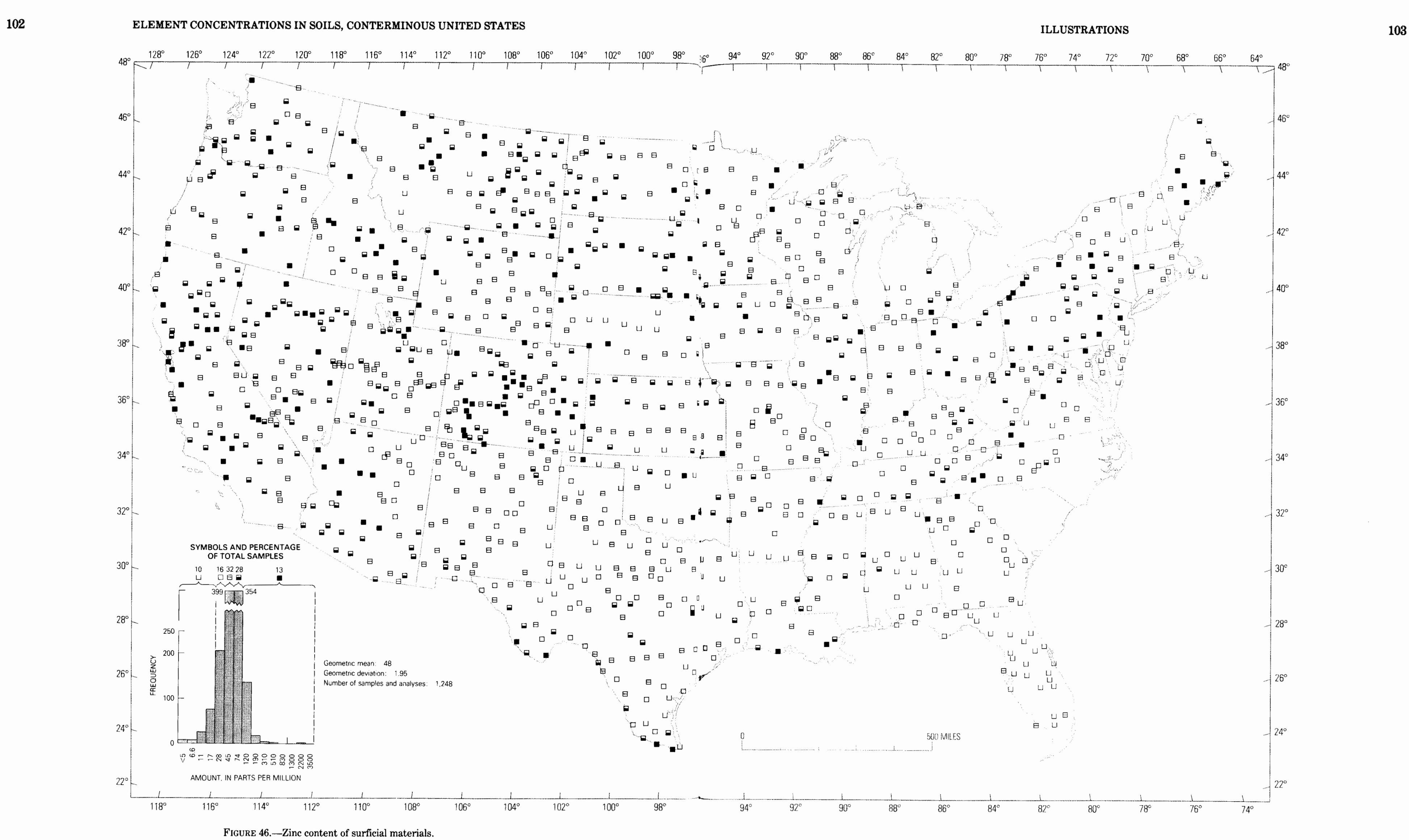




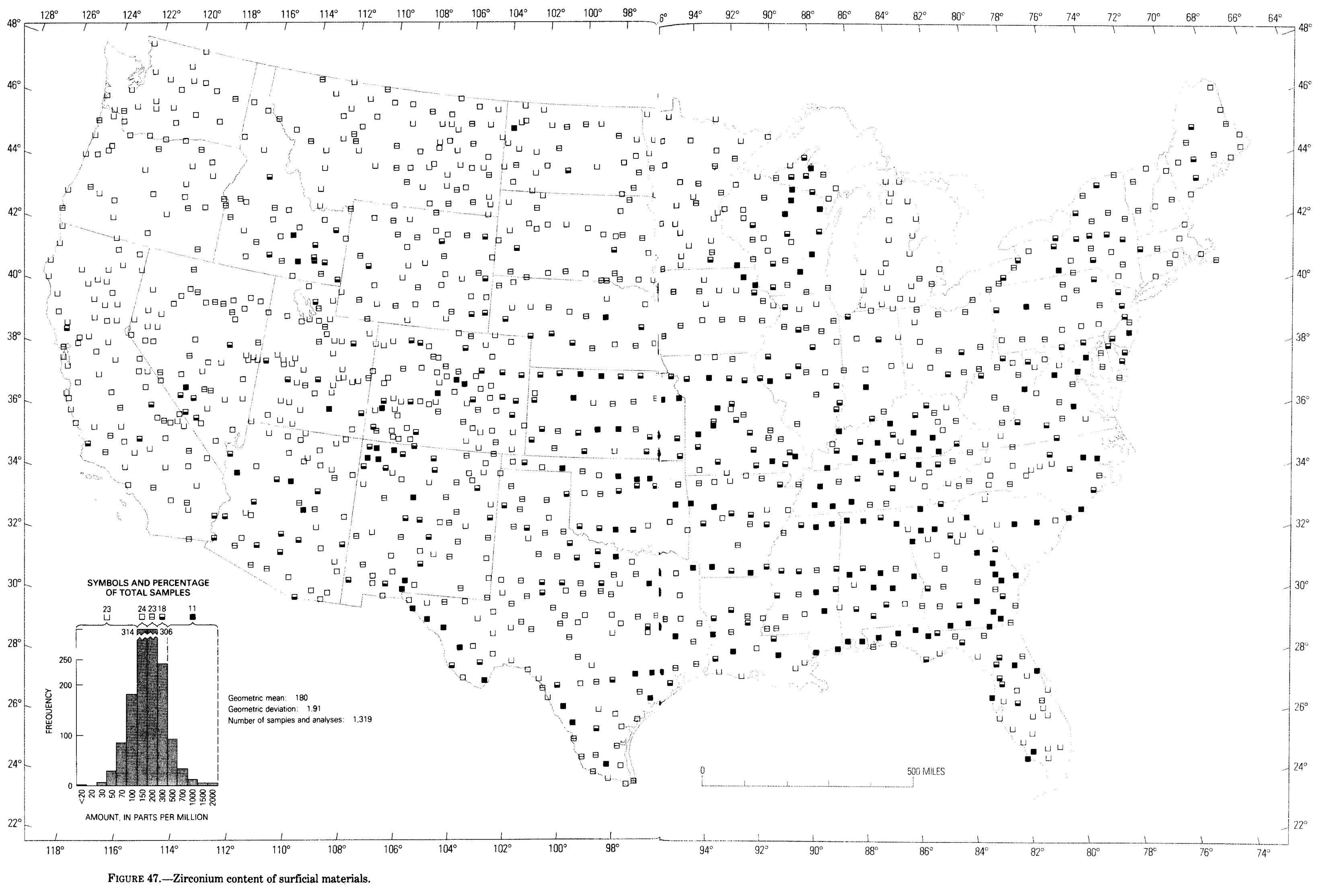

